The State and Islam in Soviet Central Asia

by

\title{
Behruz Davletov
}

A thesis submitted to the Faculty of Graduate and Postdoctoral Affairs in partial fulfillment of the requirements for the degree of

\author{
Master of Arts \\ in \\ European, Russian and Eurasian Studies
}

Carleton University

Ottawa, Ontario

(C) 2019

Behruz Davletov 


\section{Abstract}

This study explores the relationship between Islam and the Soviet state from the Second World War to the 1980s. The Spiritual Administration of the Muslims of Central Asia and Kazakhstan (SADUM), a centralized Islamic institution in Central Asia, played a key role in this relationship. SADUM represented an attempt to harmonize the Islamic and socialist worldviews and promote a new vision of Islam to the domestic and international Orient. The Soviet state's interaction with Islam and its institutional basis followed the trend of modernizing Muslim states in the Middle East. Secular states like Turkey and Egypt had been experimenting with modern institutions similar to SADUM to promote state-controlled Islam. SADUM's exchanges with these counterpart institutions from Middle Eastern countries and its domestic role in Central Asia as a religious authority highlight the Islamic image of the Soviet Union. 


\section{Contents}

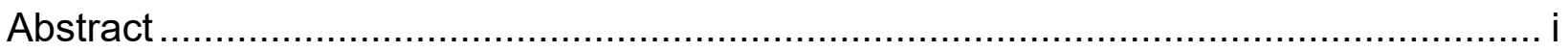

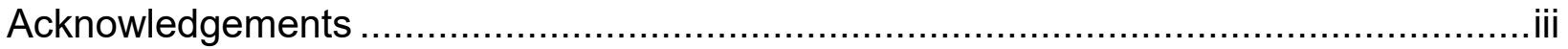

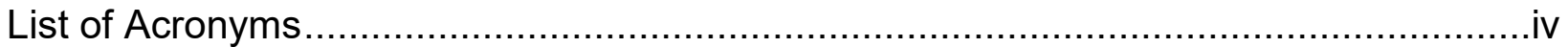

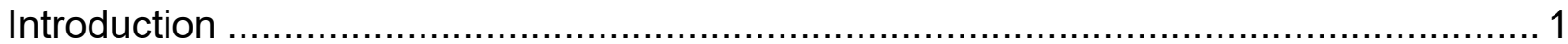

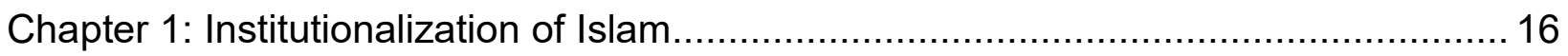

The Soviet East as an "Anchor of Socialism in the Orient" ..................................... 17

Institutionalization of Islam in Turkey and Turkish Secularism ................................ 21

Establishment of Religious Organizations during and after the Second World War ... 24 Institutionalization of Soviet Islam: The Establishment of SADUM........................... 26

What was the Role of CARC in Managing SADUM? ............................................ 35

Chapter 2: SADUM as a Diplomatic Organization ................................................... 40

Was SADUM only a Showcase to the Foreign East? ........................................... 41

Emergence of SADUM in the International Arena during the Khrushchev era ........... 43

To Game the Soviet System during the Brezhnev era .......................................... 54

After the Soviet Invasion of Afghanistan ............................................................... 57

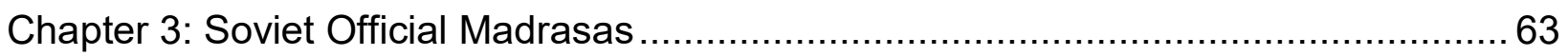

Official Madrasas as an Institution to Discipline Soviet Muslim Citizens .................... 65

Soviet Madrasas Follow Trends in the Middle East .............................................. 70

Curriculum Change in late 1960s................................................................... 73

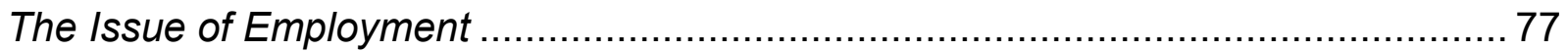

Relationship between Official and Unofficial Madrasas ........................................ 80

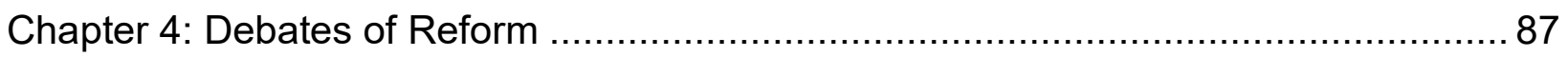

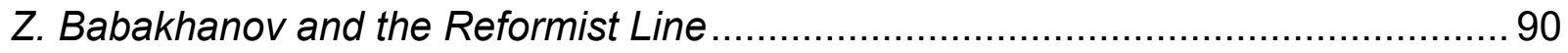

Examples of Fatwas Issued by Mufti Z. Babakhanov ............................................ 93

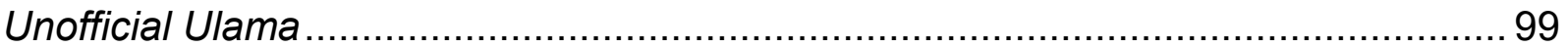

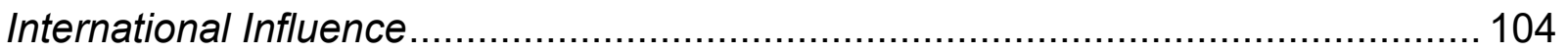

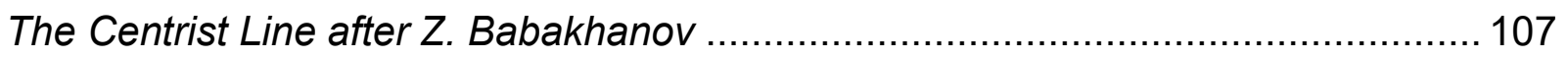

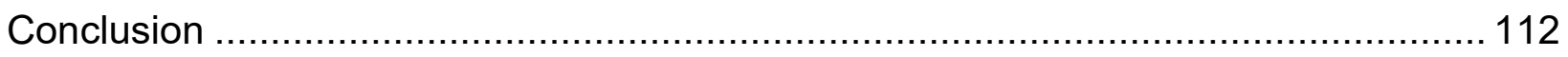

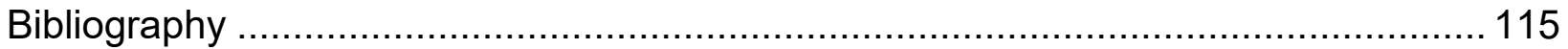




\section{Acknowledgements}

I thank my supervisor, Professor Jeff Sahadeo, for his invaluable support and guidance throughout my studies and writing of this paper. This paper would not be as good without his passion and local understanding of Central Asia. I also thank Professor James Casteel and Professor Erica Fraser for their insightful comments on this thesis. I thank Paul Gosselin and Stephen Andrew Kai Tai Lo for proofreading my paper and dealing with the casualties of my struggle with English. I would like to thank the Institute of European, Russian and Eurasian Studies at Carleton University for providing me with a chance to study and realize my research ambitions in Soviet history, as well as give me a reason to endure Ottawa's winter-scape. I thank my colleagues for their understanding and help, for showing me the hospitality of "Canadian friendship." I thank Krysia Kotarba for her kind-hearted support and putting a smile on administrative issues. Finally, I thank my parents, brother and sisters for their patience, love and support. 


\section{List of Acronyms}

SADUM .................................. The Spiritual Administration of Muslims of Central Asia and Kazakhstan CARC The Council for the Affairs of Religious Cults

CRA... The Council for Religious Affairs

TsDUM The Soviet Central Directorate of Muslims

Diyanet . The Directorate of Religious Affairs of Turkish Republic 


\section{Introduction}

At the height of the Second World War, Joseph Stalin allowed believers of all religions to partially restore their spiritual life. The Soviet state, being in a difficult situation at the end of 1942, allowed the opening of religious associations and mosques in the cities of the USSR to raise the morale of its citizens. As a result, several religious organizations emerged during the mid-1940s. In 1943, the Soviet regime established the Spiritual Administration of the Muslims of Central Asia and Kazakhstan (SADUM), an official organization responsible for managing religious activities and mosques in the Central Asian republics. In 1944, the Council for the Affairs of Religious Cults (CARC) was established as a state body to administer all religious organizations in the USSR. In 1945, the famous Miri Arab Madrasa in Bukhara reopened and started to teach Islamic theology.

SADUM's official activities included managing reopened madrasas (religious educational institution) with a limited number of students, sending students to Middle Eastern countries, and building ties with foreign Muslim organizations. In addition, SADUM published a journal, Muslims of the Soviet East, in English, French, Arabic, Persian and Uzbek to convey a positive image of Islam in the USSR for foreign Muslim audiences. The Soviet state allowed these domestic and international activities as a way to monitor, limit, and control religion through bureaucratic institutions, and prevent Islamic networks from conducting informal activities. 


\section{Institutionalization of Islam under the control of the Soviet state}

Islamic principles and values infused the social, economic, legal, and personal lives of Central Asian Muslims before the Soviet Union. Sharia was not only a body of laws or constitution, but a way of living which dealt with customs, various local practices, and rituals. ${ }^{1}$ The expansion of the Bolshevik state into Central Asia confronted local Muslim societies with a different, secular legal and value system, forcing communities to navigate between their own traditions and the new political authorities. ${ }^{2}$ Before the establishment of the Soviet state, religious matters were intertwined with local social and political systems. As such, the functions of religious figures such as imams (a leading position in prayers and communities, usually connected with a specific mosque) and scholars such as in presiding over marriages and issuing opinions on issues, had legal status. Under the secular legal system however, the imam did not have power over legal issues. Therefore, Islam became a private matter, a customary practice. ${ }^{3}$ In this process, the Soviet secular state established SADUM that claimed authority over religious affairs. The institutionalization of Islam in the USSR created an Islamic space with borders that were defined by the Soviet state.

The institutionalization of Soviet Islam could be analyzed in Weberian terms of charismatic authority. While the charismatic authority of religious leaders is temporal,

\footnotetext{
${ }^{1}$ Sirelkhatim Mohamed, "Authority in Islam: The Institutionalization of Islam and the Elusive Transfer of Authority from Society to State," Journal of Georgetown University-Qatar Middle Eastern Studies Student Association 2015, no. 1 (March 18, 2015): 2.

${ }^{2}$ Seyfettin Erşahin, "The Official Interpretation of Islam under the Soviet Regime: A Base for Understanding the Contemporary Central Asian Islam," Hamdard Islamicus: Quarterly Journal of Studies and Research in Islam 28, no. 4 (2005): 7-25.

${ }^{3}$ Michael Kemper, Studying Islam in the Soviet Union, vol. 321 (Amsterdam University Press, 2009), 7; Adeeb Khalid, Islam after Communism: Religion and Politics in Central Asia (Berkeley: University of California Press, 2007).
} 
the institutionalization of religious authority leads to the routinization of charisma and the continuity of authority. ${ }^{4}$ Religion is a powerful source for mobilizing people; hence the presence of religious activities could threaten any state. Since the state has defined borders and a defined structure, its rule over society naturally gravitates towards classifying and managing bounded areas, such as in distinguishing secular and religious domains. The area in which religion is bounded and settled must be constantly redefined, because social life is constantly reproducing new religious practices, thereby subverting the borders of the state and altering the defined areas. The routinization of charisma and the establishment of religious institutions (can) benefit the state if such institutions effectively control religious activities.

The Soviet Union sought to restrict the basic aspects of Soviet religious life within predictable parameters through founding formal religious institutions. Everyday Muslim life must only include approved practices, figures, and institutions. ${ }^{5}$ In this way, Soviet secularism routinized religious charisma and practice to discipline religious citizens as more obedient, predictable, and controllable. The bureaucratization of religious policy, therefore, enhanced the party-state's penetration into the religious landscape and into the private realm of its citizens in the Soviet Union. ${ }^{6}$

\section{Secularism}

Talal Asad's conceptualization of secularism is useful for the Soviet Union as it acknowledges different types of secularisms. Asad claims that the most important goal

\footnotetext{
${ }^{4}$ Peter Berger, "From Sect to Church: A Sociological Interpretation of the Baha'i Movement" (Ph. D., New School for Social Research, 1954), 157.

5 Eren Murat Tasar, "Soviet and Muslim: The Institutionalization of Islam in Central Asia, 1943-1991" (Ph.D., Harvard University, 2010)., 173.

6 İştar B. Gözaydın, “Diyanet and Politics," The Muslim World 98, no. 2-3 (2008), 217.
} 
of modernism as a political project is to institutionalize all aspects of social life, religion and the promotion of secular values. ${ }^{7}$ In examining the historical development of secularism, Asad argues that secular discourse uses old religious concepts and structures but changes their meaning. The state law, for instance, which is valid in every corner of the modern nation-state, takes the place of the idea of God, who sees everything in every place. In this sense, in modern secular societies, not only the law but even faith in the validity and power of law fulfills the self-disciplining function of individual behavior. Therefore, contrary to the expectations of many sociologists like Durkheim, religions have continued to maintain their social presence in modern societies. This tenuous relationship between modern secular and religious fields changed the meaning and practice of religion. ${ }^{8}$ The Soviet Union is merely one of a few unique examples of this tenuous relationship between secularism and Islam. It is unique because of the severity and longevity of the atheist regime's assault on Islam.

The Soviet Union established and used SADUM to institutionalize all aspects of social life and to discipline society by drawing clear borders between secular and religious domains. Yet, as will be discussed in Chapter One, the border between secular and religious institutions was not very clear in practice, and Soviet-style secularism was not neutral to religion, but more intrusive.

The Soviet understanding of "secular", or svetskiy (also meaning "educated" or "enlightened"), featured elements from and shifted between the "skeptical/insulating" and "hostile" models identified by Svante Cornell and Jacob

\footnotetext{
${ }^{7}$ Talal Asad, Formations of the Secular: Christianity, Islam, Modernity (Stanford University Press, 2003$), 13$.

${ }^{8}$ Asad, 193.
} 
Zenn in state relationships with religion. ${ }^{9}$ The "skeptical/insulating" model, best exemplified by the French policy of laïcité, adopts a skeptical approach to religion that seeks to insulate the state from the influence of religion. In the "hostile" model, the state is actively opposed to any manifestation of religion. Whereas sometimes the Soviet state carried out anti-religious campaigns (including in the Khrushchev era), eliminating it from all parts of life, during other relatively moderate periods, such as under Brezhnev, relations between the state and Islam were more stable.

The attempt to control and reshape Islam was not only an experiment specific to the Soviet Union. Similar projects were implemented in Turkey and Egypt, and the modern state penetrated all parts of the Islamic world. Islam has not been unaffected in this process, which has taken place in different countries, albeit in different forms depending on the structure and power of the state, and under the influence of different historical processes. Soviet secularism and its relationship with Islam resemble the Turkish secularism, or laiklik, where the "protection of the state from religion goes well beyond separation to a pervasive effort by the state to define, shape and control religion." 10 Turkey was "the first country in the Muslim world to completely abolish the sharia, including elements of family law that other modernizing countries maintained, and replaced most traditional Islamic institutions." Similarities between Turkish and Soviet secularisms will be discussed in detail in Chapter One.

\footnotetext{
9 Svante E. Cornell and Jacob Zenn, "Religion and the Secular State in Uzbekistan," Uzbekistan's New Face, 2018, 193.

${ }^{10}$ Martin van Bruinessen, "The Governance of Islam in Two Secular Polities: Turkey's Diyanet and Indonesia's Ministry of Religious Affairs," European Journal of Turkish Studies. Social Sciences on Contemporary Turkey, no. 27 (December 31, 2018), http://journals.openedition.org/ejts/5964.
} 


\section{Official and unofficial Islam in the Soviet Union}

The SADUM leadership was controlled by the CARC, local governments, and the Committee for State Security (KGB). However, there was an informal network, so called "unofficial Islam", comprised of Muslim clergy who practiced religion outside of the state limits. These informal networks did not follow SADUM in their rituals or understanding of dogmas. The fact that religious figures like Domulla Hindustani could establish their own network of influence through informal madrasas and mosques shows the resilience of these community-based solidarity networks outside of the state. People continued to visit shrines and celebrate circumcision, weddings, and burial ceremonies according to traditional religious practices which were often led by official or unofficial clergy, or some local respected elders. ${ }^{11}$

The tenuous relationship between formal and informal networks tends to be a challenging area of research for historians of Soviet Islam. Bennigsen and LemercierQuelquejay categorized the religious practices in the USSR as official and unofficial Islam. ${ }^{12}$ Their ideas were based mostly on official documents, journals, and newspapers which were accessible at that time. However, the new generation of Soviet historians like Khalid, Tasar, and Babajanov dispute this categorization, instead arguing that classifying the religious field in the Soviet era as official and unofficial Islam is too simplistic, because the relationship between officially registered and unregistered clergy is not precisely separated and is more complex. Khalid, too, expresses opposition to the

\footnotetext{
${ }^{11}$ Khalid, Islam after Communism, 102.

12 Alexandre Bennigsen and Chantal Lemercier-Quelquejay, "'Official' Islam in the Soviet Union," Religion in Communist Lands 7, no. 3 (1979): 148-59.
} 
official-unofficial dichotomy, ${ }^{13}$ although he uses the concepts of official and unofficial Islam in his analysis. Unofficial networks also penetrated state institutions, as some members of SADUM and imams of registered mosques were also part of informal networks. Some of the official clergy, such as Ismail Sattiyev, had their own informal madrasas, challenging borders between official and unofficial realms.

Although this study agrees with Tasar and Babajanov in that the distinction between official and unofficial networks is an overly simplistic approach, it also acknowledges the difficulty of avoiding this categorization and as such, this paper frequently uses these categories. This categorization seems like a difficult "trap" for historians to avoid. The establishment of SADUM penetrated and changed local patterns of relations among religious actors, and created an official domain, no matter how complex its relations with society were.

\section{Reformist and Traditionalist views}

Central Asian Muslims traditionally followed the teachings of the Hanafi madhab (a theological and juridical school). ${ }^{14}$ The pre-Soviet traditional ulama (scholars) in Central Asia tolerated the local practices of Islam in the region, which were syncretic, combining pre-Islamic and Islamic practices. The traditional understanding of Islam was

\footnotetext{
${ }^{13}$ Khalid states that unofficial Islam cannot be seen as a single phenomenon, apart from and in opposition to official Islam, and that 'the connections were much more complicated for such a simple dichotomy to explain anything'. Khalid, Islam after Communism, 112.

${ }^{14}$ Sunni Islam mainly consists of four schools of jurisprudence (madhabs) named after the founding jurist: Hanafi, Shafi'i, Maliki, and Hanbali. These madhabs were formed in $9^{\text {th }}$ century. They are practiced in different regions of the world, but each madhab dominates a specific region. The Shafi'i madhab, for instance, is predominant in East Africa, the Maliki in North Africa, the Hanbali in North Arabia, and the Hanafi school is dominant in Central Asia. Sharia (or Islamic law) was implemented according to dominant school in the region. Although these four schools of thought have different interpretations and opinions about legal or religious affairs, they do accept each other as valid. For more details see Iza R. Hussin, "Sunni Schools of Jurisprudence," in The Oxford Encyclopedia of Islam and Politics, ed. Emad El-Din Shahin et al. (Oxford University Press, 2014); Iza R. Hussin, The Politics of Islamic Law: Local Elites, Colonial Authority, and the Making of the Muslim State (Chicago: University of Chicago Press, 2016).
} 
also strongly related to local customs and various commentaries of the Quran and hadith by classical, medieval Islamic scholars.

However, reformists criticized these local traditional practices and denounced them as being incompatible with Islam. Some of these reformists were Salafi Muslims, who rejected all schools of Islamic jurisprudence and accepted only the original teachings of (Islam that dated from the time of) the first Muslim society based on the canonical texts, the Quran and hadith. ${ }^{15}$ Jadidis, a modernist movement that emerged in the late $19^{\text {th }}$ century, was another reformist movement which criticized local customs and traditional understanding of Islam. Jadidis, unlike Salafis, did not reject the Hanafi madhab, but attempted to modernize Central Asian Muslim life through education in modern schools. ${ }^{16}$

Reformists such as Abduvali Qori and Rahmatulloh Alloma were promoting a "Salafi reformation," similar to the adherents of Abd Al-Wahhab (1703-1791) in Arabia who attempted to "purify" Islam and return to "the Prophet's time." However, in Soviet Central Asia the term "Wahhabi" was also used incorrectly to refer to local theologians (or anyone) who criticized the "excesses" and "corruption" of local practices, such as the "saint worship" prevalent in Central Asia. ${ }^{17}$

\footnotetext{
${ }^{15}$ Martha Brill Olcott, "Roots of Radical Islam in Central Asia," Russia and Eurasia Program (Washington: Carnegie Endowment for International Peace, January 2007), https://carnegieendowment.org/2007/01/17/roots-of-radicalislam-in-central-asia-pub-18967.

${ }^{16}$ Adeeb Khalid, The Politics of Muslim Cultural Reform: Jadidism in Central Asia, vol. 27, Comparative Studies on Muslim Societies (Berkeley: University of California Press, 1998).

${ }^{17}$ Olcott, "Roots of Radical Islam in Central Asia"; Sebastien Peyrouse, "The Rise of Political Islam in Soviet Central Asia," Current Trends in Islamist Ideology; Washington 5 (2007): 40-54, 83.
} 
Although reformists criticized local traditional understanding and practice of Islam in Central Asia (the Hanafi school of jurisprudence), it is difficult to name this reformist approach using terms like "fundamentalist" or "puritanical", as it might be confusing because both reformists and traditionalists used and referred to the same original texts. In addition, concepts like "fundamentalist" have a negative connotation. Therefore, scholars such as John Esposito suggest using terms like "Islamic revivalism." ${ }^{18}$ Both traditionalists and reformists tried to revive Islam, but in different ways. While traditionalists tried to revive religion through the Hanafi school of jurisprudence, reformists tried to revive it by reinterpreting the original texts. Thus, reformism was actually a reinterpretation of canonized texts. Then the question will be what kind of reinterpretation? Jadidis tried to reinterpret the Quran and hadith in order to make Islam compatible with modernity. However, "local Wahhabis" radically opposed modernity and instead tried to strictly follow the text. On the other hand, SADUM leaders such as Z. Babakhanov attempted to reinterpret the Quran and hadith in order to make Islam compatible with socialism. It would be easier to understand Islamic revivalism in Soviet Central Asia by differentiating three distinct reformists: Jadidis (modernist), "local Wahhabis" (radically against modernism and socialism), and SADUM (modernist and socialist).$^{19}$

\footnotetext{
${ }^{18}$ John L. Esposito, Political Islam: Revolution, Radicalism, or Reform? (Lynne Rienner Publishers Boulder, CO, 1997).

${ }^{19}$ Eren Murat Tasar, "The Official Madrasas of Soviet Uzbekistan," Journal of the Economic and Social History of the Orient 59, no. 1-2 (2016): 265-302; Bakhtiyar M. Babajanov, Ashirbek Muminov, and Anke von Kügelgen, Disputy musul'manskikh religioznykh avtoritetov v Tsentral'noy Azii v XX veke (Almaty: Dayk-Press, 2007); Khalid, The Politics of Muslim Cultural Reform.
} 
SADUM, in line with the Soviet modernization project, issued some controversial fatwas (nonbinding opinion of a scholar on legal and religious affairs), especially during Ziyauddin Babakhanov's leadership (1957-1982), that took a modernist-reformist approach to important religious matters for example, judging fasting during Ramadan as non-obligatory for workers and the hijab (headscarf) as non-obligatory for women. ${ }^{20}$ These fatwas might suggest that SADUM acted under the guidance of the Soviet regime. However, SADUM's position changed over time. The style and views of Z. Babakhanov (1957-1982), the second mufti (an Islamic scholar or a jurist who issues nonbinding opinion on legal and religious matters) of SADUM, clearly and substantially differed from the last mufti Muhammad Sodik (1989-1993). Their ideas and the shift in their views also seem to be following the contemporary views of international Muslim scholars.

\section{Chapter Outline}

This research will primarily focus on SADUM as an Islamic institution, and the relevant time period will extend from the establishment of SADUM in 1943 to the early 1980s. The scope of this study covers three different periods: 1943 to 1953 , when the regime took a moderate position towards religious actors; 1953-1964, during antireligious campaigns of the Khrushchev era; and from 1964 to the early 1980 s before perestroika.

SADUM was headquartered in Tashkent, Uzbek SSR, yet its scope geographically covered the whole of Soviet Central Asia. This study will center on

\footnotetext{
${ }^{20}$ Bakhtiyar M. Babajanov, “O fetvakh SADUM protiv 'neislamskikh obychaev,'” in Islam na postsovetskom prostranstve: vzglyad iznutri, ed. Aleksey V. Malashenko and Martha Brill Olcott (Moskva: Moskovskiy Tsentr Karnegi, 2001); Tasar, "The Official Madrasas of Soviet Uzbekistan."
} 
SADUM's headquarters in Tashkent, in particular its relations with Moscow through the CARC, as well as transnational relations with other religious institutions from Muslim countries in the Middle East, such as Al Azhar University in Egypt.

The first chapter narrates the history of the institutionalization of Islam in the USSR, starting from the formation of the USSR until 1964. It also explores the conditions of relations between SADUM and the CARC, specifically the role of the CARC in managing religious activities and controlling mollas (an Islamic cleric educated in theology and religious law, also may hold a position in local mosque) and mosques.

The second chapter explores SADUM's role as a bridge between the Soviet East and the foreign East from 1954 until the early 1980s. The Soviet state relied on Central Asian Muslim individuals and institutions to promote an Islamic image of the USSR to foreign Muslim countries.

The third chapter studies Soviet official madrasas managed under SADUM from 1945 until the early 1980s. Similar to its uses of SADUM, the state also used madrasas to show the freedom of conscience in the USSR. In domestic affairs the official madrasas channeled Islam to generate pragmatic Muslim cadres for the Soviet bureaucracy who were both practicing believers and loyal servants of the state.

The fourth chapter looks at the debates among local official and unofficial Islamic scholars over religion and explores SADUM's position from 1952 until the early 1980s. Generally, there were three different views among religious scholars in Soviet Central Asia: reformist, traditional, and centrist, with SADUM's position shifting from reformist to 
centrist. It will also explore the effect of SADUM's official struggle against unorthodox religious innovations on Islamic discourse during the Soviet era.

Although the Soviet state's attitude towards Islam shifted throughout these different periods, the overall nature of relations between the state and Islam generally remained ambiguous. Ambiguity stemmed from the different needs and goals of different actors, such as SADUM, the CARC, local governments, and security services. During the Khrushchev years, Soviet policies towards Islam became more ambiguous because of the state's anti-religious campaign. However, in the late 1960s, Islam was considered favorably to serve progressive nationalist leaders abroad in their fight against colonialism. In the 1970s under Brezhnev, Islam abroad was considered compatible with communism and a stimulus of progress. Yet, in the domestic arena, different criteria were still applied to evaluate Islam. ${ }^{21}$ The different needs of Soviet domestic and foreign affairs engendered these various and sometimes contradictory state attitudes towards Islam.

\section{Sources}

This paper used original Russian-language archival material published by Dmitry Arapov as a primary source. ${ }^{22}$ The collection includes documents describing the policy of the Soviet state towards Islam from 1944 to 1990, and the archival materials of the Council for Religious Cults (1944-1965) and the Council for Religious Affairs (19651990), such as reports, inquiries, recordings of conversations with Muslim figures, and various texts about "foreign" Islam. In addition, Volumes 1 (1968) and 73 (1987) of

\footnotetext{
${ }^{21}$ Yaacov Ro'i, The USSR and the Muslim World: Issues in Domestic and Foreign Policy (Routledge, 2015), 150.

${ }^{22}$ Dmitriy Arapov, Islam i sovetskoe gosudarstvo (1944-1990). Sbornik dokumentov. Vypusk 3 (Moskva: Mardzhani, 2011).
} 
Muslims of the Soviet East journal published by SADUM in Tashkent in English were also used as primary sources.

Other sources in Russian include Imam-Khatib of the Nizhny Novgorod Cathedral Mosque Umar Idrisov's autobiographical Bukhara Memories which includes memoirs about the Miri Arab madrasa and the Tashkent Islamic Institute. ${ }^{23}$ His memoirs show the colorful lives and vibrant environment of students in madrasas. Amirsaid Usmanhojanyev's book Lives of the Babakhanov Muftis in Russian includes biographies of the Muftis Eshon Babakhanov, Ziyauddin Babakhanov, and Shamsuddin Babakhanov. ${ }^{24}$ The book also includes three fatwas issued by Z. Babakhanov, the second mufti and chairman of SADUM.

Bakhtiyar Babajanov's Disputes of Muslim Religious Authorities in Central Asia in the 20th Century, includes writings of Muslim intellectuals of the Soviet period, found in private archives. ${ }^{25}$ Texts are presented in their original forms in Arabic, Tajik, and Uzbek and in translations into Russian and English. These primary sources are important for an adequate understanding of the phenomenon of "Soviet Islam" in Central Asia. They reflect disputes and schisms among the local ulama, often acquiring a sharp political character.

Secondary sources

\footnotetext{
${ }^{23}$ Umar Idrisov, Bukharskie vospominaniya. 20 let sluzheniya imamom (Nizhniy Novgorod: Izdatel'skiy Dom “Medina," 2007), http://www.idmedina.ru/books/encyclopedia/?765, accessed 8/2/2019.

${ }^{24}$ Amirsaidkhan Usmankhodzhaev, Zhizn' muftiev Babakhanovykh: sluzhenie vozrozhdeniyu Islama v Sovetskom Soyuze (Nizhniy Novgorod: Izdatel'skiy Dom “Medina," 2008),

http://www.idmedina.ru/books/history_culture/?1201, accessed 8/2/2019.

${ }^{25}$ Babajanov, Muminov, and Kügelgen, Disputy musul'manskikh religioznykh avtoritetov.
} 
Adeeb Khalid's Islam After Communism, a historical overview of the relationship between Islam and the state covering the period from the pre-Soviet through the postSoviet times in Central Asia, was used as a secondary source. ${ }^{26}$ Although his analysis does not often discuss SADUM, it was useful as a framework for understanding the domestic religious policies of the Soviet state and the transformation of Islam under the Soviet state.

Yaacov Roi's Islam in the Soviet Union is one of the first books primarily based on official Soviet archives related to religious affairs, specifically Islam. ${ }^{27}$ It covers the domestic and transnational dimensions of Soviet policies regarding Islam. Roi also explains how Islam was used in propaganda to Middle Eastern countries. Analytically, however, Roi's book neglected bottom-to-top perspectives, and mainly focused on the party-state's policies towards Islam. ${ }^{28}$ Eren Tasar's Ph.D. thesis Soviet and Muslim about the institutionalization of Islam in Soviet Central Asia complements, to some degree, gaps in Y. Roi's analysis. ${ }^{29}$ Tasar's thesis is a comparative-historical study of the relations between SADUM and the CARC. It also explores the transnational relations of SADUM with Middle Eastern Muslim countries. Tasar specifically discusses the contradictory policies of the secular Soviet state towards Islam.

E. Tasar put too much emphasis on SADUM's role in international affairs. Masha Kirasirova's Ph.D. thesis, The Eastern International, was useful to balance Tasar and

\footnotetext{
${ }^{26}$ Khalid, Islam after Communism.

27 Yaacov Ro'i, Islam in the Soviet Union: From the Second World War to Gorbachev (Columbia University Press, 2000).

${ }^{28}$ For more detailed critical review of Y. Roi's book see Devin DeWeese, "Islam and the Legacy of Sovietology: A Review Essay on Yaacov Ro'i's Islam in the Soviet Union," Journal of Islamic Studies 13, no. 3 (2002): $298-330$.

${ }^{29}$ Tasar, "Soviet and Muslim."
} 
Roi's bias, and also to locate SADUM in a broader post-World War II restructuring in Soviet foreign affairs. Kirasirova explored Cold War era interactions between the Soviet Union and the Middle Eastern countries. ${ }^{30}$ Kirasirova situates the Soviet Union in a postWorld War II decolonization context, which explains how exchanges with Middle Eastern countries impacted and structured Soviet bureaucracies and institutions. Kirasirova's thesis was very useful to support the idea of how the Soviet state used Central Asians to propagate an Eastern and Islamic image of Sovietness to Middle Eastern countries. This research uses it as a primary framework to locate SADUM's role in the international relations of the Soviet Union with the Middle Eastern countries. The Soviet perception of the "East" and the "new Eastern politics" during Khrushchev's leadership reshaped domestic policies towards Islam. In the domestic area, the expression of the "Muslim East" connoted the Bolshevik attempt to get the Muslims in Central Asia to accept socialism by offering the freedom to practice religion and local traditions. Building on this approach, this paper argues that rather than imposing specific state goals of reforming Islam from the top down within this "Eastern" image, the state relied on Muslims within SADUM to define this reformist vision of religion for the East.

\footnotetext{
${ }^{30}$ Masha Kirasirova, "The Eastern International: The 'Domestic East' and the 'Foreign East' in Soviet-Arab Relations, 1917-68” (Ph.D., New York University, 2014).
} 


\section{Chapter 1: Institutionalization of Islam}

In 1943, Stalin approved the establishment of the Muslim Religious Board of Central Asia and Kazakhstan (SADUM). SADUM officially represented the religious affairs of the Muslims of the five Central Asian republics of the Soviet Union - Kazakh, Kyrgyz, Tajik, Turkmen, and Uzbek SSRs. Its headquarters were located in Tashkent, and it was one of the few organizations in the USSR whose jurisdiction went beyond the boundaries of any single national republic. SADUM's most important tasks were to control the Muslim community and religious life of Central Asia and to promote the Soviet state abroad to other Muslim countries. ${ }^{31}$ The Soviet state regarded religion as an institution of capitalism and therefore a threat against communism, yet here religion became an instrument of the state. How and why did the Soviet secular state come to control religious institutions? What was the role of local ulama in the establishment and management of religious institutions? This chapter will explore the institutional foundations of the relationship between the state and Islam in Soviet Central Asia from the formation of the USSR to the 1960s. In addition, it will examine agency of local Muslim clergy and their relationship with the Council of Religious Affairs, a state body managing all the Soviet religious organizations.

Moreover, while the rest of this paper will focus primarily on post-World War II Soviet Central Asia, this chapter will specifically highlight two important contextual developments behind the institutionalization of Islam that predate the Second World War. First, SADUM was not the first Muslim organization that aimed to control religion in

\footnotetext{
${ }^{31}$ Eren Murat Tasar, "Soviet and Muslim: The Institutionalization of Islam in Central Asia, 1943-1991" (Ph.D., Harvard University, 2010), 336.
} 
the Soviet Union, and the foundations of similar organizations can be traced back to before the Second World War. Second, the Soviet Union was not alone in its attempt to control Islam through central religious organizations like SADUM. Muslim countries such as Turkey and Egypt had been experimenting with similar institutions since the 1920s. These historical processes are important in exploring the nature of both Soviet secularism specifically and the role of official religious authorities under secular states in modern Islam more broadly.

\section{The Soviet East as an "Anchor of Socialism in the Orient"}

In 1917, the Orenburg Mohammedan Spiritual Assembly, a local religious organization taken over by Bolsheviks, which was established in $18^{\text {th }}$ century, was renamed the Central Spiritual Board of the Muslims (TsDUM) of Inner Russia and Siberia. TsDUM was the first central Muslim organization that attempted to control Islam in the new Bolshevik state, and later became a model for other religious organizations within the Soviet Union.

The Bolsheviks attempted to build a new communist world breaking radically with the past. They envisioned using Islamic revolutionary movements abroad for their own cause. The colonized East was important for the Communist International from the early years of the Bolshevik revolution. Lenin expressed a revolutionary vision of mobilizing Eastern countries for the socialist cause, predicting in a 1919 speech a new period in world history "when the peoples of the East play an active part in deciding the destinies of the whole world, and when they have become a new and mighty factor in 
international relations." ${ }^{32}$ Konstantin Mikhailovich Troianovskii, a Bolshevik scholar of the East who coined the term "Eastern International", outlined in his 1918 The East and the Revolution a program for liberating colonized and semi-colonized regions of the East, in which the Bolsheviks' objective was "to create an Eastern International- a united formidable anti-imperialist front that could oppose the Western international". ${ }^{33}$

Troianovskii imagined the "Eastern International" as a social, geographical and political unit coalescing around the unifying potential of Islam, a union of pan-Islamic movements cutting across Iran, India, and China. He believed in the greater potential of Islam as a political religion that could organize a cohesive extraterritorial and transnational power. ${ }^{34}$

As Russian Orientalist scholarship in service of the Bolshevik cause and state matured into the new discipline of Soviet Orientology, it further differentiated the East into the "Socialist Orient" - those "Eastern" parts of the former Russian Empire now under Soviet control - and the "foreign Orient." Stalin first articulated this idea of the "two Orients" in 1925. The national republics of the Soviet East were imagined as "anchors of socialism in the Orient" where the Bolsheviks had successfully overthrown imperialist oppression. ${ }^{35}$ The Soviet concept of the "two Orients" demonstrated that it was possible for the exploited and under-developed East to jump from feudalism to socialism while bypassing capitalism. Thus, the Soviet-East in these terms served as an

\footnotetext{
32 Masha Kirasirova, “The Eastern International: The 'Domestic East' and the 'Foreign East' in Soviet-Arab Relations, 1917-68" (Ph.D., New York University, 2014), 340.

${ }^{33}$ Kirasirova, 51.

${ }^{34}$ Kirasirova.

${ }^{35}$ Masha Kirasirova, “Orientologies Compared: US and Soviet Imaginaries of the Modern Middle East," in Reassessing Orientalism (Routledge, 2015), 17.
} 
example of a different route to progress than the foreign East, where "imperialist oppression was still in full force" and which was still trying to liberate itself from Western-Capitalist colonialism. ${ }^{36}$

Such ideas of establishing an Eastern International or mobilizing Islam for the global socialist cause motivated the establishment of various institutions similar to the future SADUM. Shortly after the October Revolution, Stalin, in his capacity as Nationalities Commissar, oversaw the establishment of the Commissariat for Muslim Affairs (Muskom) in order to manage domestic Muslim citizens. The first conference of Muskom in 1918 expounded "Islamic communism" as a mechanism of connecting and solidifying ties between Soviet and foreign Muslim peoples. ${ }^{37}$ Muskom further undertook the organization of Central Bureau of the Communist Organizations of the People of the East (Musburo), which included international departments responsible for different regions and research in languages such as Arabic, Persian, Turkish and Chinese, and printed and distributed more than 400,000 newspapers and brochures in various foreign languages..$^{38}$

However, the relative domestic "peace" between the Bolsheviks and Islam in the Soviet Union in the 1920s was temporary. Despite early visions of accommodating Islam in the Eastern struggle against imperialism, the documents of chekists (intelligence officers) emphasized the inevitable future expulsion from Soviet life of all "religious remnants," including Islam, and the creation of a society built on the principles

\footnotetext{
${ }^{36}$ Kirasirova, 17. Bakhtiyar M. Babajanov, “'Ulama'-Orientalists: Madrasa Graduates at the Soviet Institute of Oriental Studies," in Reassessing Orientalism (Routledge, 2015), 102.

${ }^{37}$ Kirasirova, "The Eastern International", 62.

38 Ibid.
} 
of pure "scientific atheism."39 The relative infancy and instability of the Bolshevik state in its first years precluded waging struggle on all fronts, including religion. However, as early as 1924 , almost all mosques and madrasas were closed, as the state shifted from accommodating religion to militant atheism.

Prominent religious leaders and ulama were imprisoned and exiled. Many emigrated to survive and keep their faith. Unique multi-volume manuscripts, some more than a thousand years old, were burned, thrown into water, and buried in the ground. It was considered a crime not only to read and study the Quran, but even to keep one at home. The oppression reached its climax in 1937-38 when mass imprisonment and murders were organized. ${ }^{40}$

Likewise, by the late 1920 s and early 1930 s, the Bolshevik state resumed its ideological commitment to the atheistic transformation of communist society and reversed the prior status quo of reconciling Islam to Soviet revolution and diplomacy. ${ }^{41}$ In contrast to the USSR's interest in Middle Eastern developments and its use of religion and domestic Muslim actors in regional diplomacy in the early 20s, by the 1930 s it had largely lost interest and influence in the region. The imprisonment and execution of the Soviet diplomat and Tatar Muslim Hakim Kerimov in 1938 poignantly sealed the Soviet state's pivot away from engaging the Islamic world through religious boards. Through Kerimov's diplomacy in Mecca, the Soviet Union was the first government to

\footnotetext{
${ }^{39}$ Dmitriy Arapov and Grigoriy Kosach, Islam i sovetskoe gosudarstvo (Po materialam Vostochnogo otdela OGPU. 1926 g.). Vypusk 1 (Moskva: Mardzhani, 2010).

40 Usmankhodzhaev, Zhizn' muftiev Babakhanovykh.

41 Yuliya N. Guseva, “Mrachnoe Ekho «Dela TsDUM»:«Tsep' Korana» i Repressii Protiv Musul'manskoy Elity v SSSR (1940 God)," Novyy Istoricheskiy Vestnik, no. 2 (52) (2017). Vyacheslav A. Akhmadullin, "Islamskiy faktor vo vneshney politike Soyuza Sovetskikh Sotsialisticheskikh Respublik," Forumy rossiyskikh musul'man. Yezhegodnyy nauchno-analiticheskiy byulleten' № 3 (2007). Arapov and Kosach, Islam i sovetskoe gosudarstvo (1926 g.).
} 
recognize Abdullah ibn Saud's nascent Hijazi state in $1926 .{ }^{42}$ The same year, TsDUM (the Soviet Central Directorate of Muslims) celebrated the independent Hijaz as the only Islamic country where it was possible to meaningfully convene an international Muslim congress on the future of the caliphate, recently liquidated in the Turkish Republic. ${ }^{43}$ Then, the Soviet government explicitly supported international Muslim condemnation of British schemes to foist a new caliphate under its own imperial control. Now, the Saudi monarch ibn Saud, formerly a loyal Soviet ally, considered his acquaintance Kerimov's murder as an act against the Saudi state and closed all diplomatic relations with the USSR. $^{44}$

\section{Institutionalization of Islam in Turkey and Turkish Secularism}

The attempt to control and reshape Islam in the early $20^{\text {th }}$ century was not specific to the Soviet Union. Modernizing states across the Islamic world implemented similar political projects of managing religion, notably in Turkey and Egypt. The practice of Islam itself was deeply affected in these projects, as processes of institutionalization across different countries depended not only on the structure and power of the local state, but on past experiences and traditions of religion as well.

Soviet secularism and its relationship with Islam resembled Turkish secularity, or laiklik, where the "protection of the state from religion goes well beyond separation to a pervasive effort by the state to define, shape and control religion." 45 The secular politics

\footnotetext{
42 Roman A. Silant'ev, Musul'manskaya diplomatiya v Rossii: istoriya i sovremennost': uchebnoe posobie (Moskva: IPK MGLU “Rema,” 2010), 120-22.

43 Dmitriy Arapov, Islam i sovetskoe gosudarstvo (1944-1990). Sbornik dokumentov. Vypusk 3 (Moskva: Mardzhani, 2011), 65-66.

${ }^{44}$ Silant'ev, Musul'manskaya diplomatiya v Rossii, 122.

${ }^{45}$ Bruinessen, "The Governance of Islam in Two Secular Polities."
} 
of the Kemalist regime in Turkey undertook Islamic reform, trying to control all aspects of religious life through the Directorate of Religious Affairs (Diyanet) ${ }^{46}$, which repurposed the Ottoman-era "Shaykh-ul Islam" office formerly responsible for controlling religious affairs. ${ }^{47}$ Turkey was one of the first countries in the Muslim world which completely abolished Shariah, including elements of family law that other modernizing countries maintained, and replaced most of the traditional Islamic institutions. ${ }^{48}$

The main aim of the modernist project of the republic's founders was to secularize and modernize not only the state but society as well. In other words, "laiklik" was central to the Kemalist vision designing the Diyanet as an administrative tool to "regulate" Islam. "Regulating" Islam was "to put orthodox Islam under the state control' and to nationalize it, while establishing secular systems of law and education, destroying the influence and power of the ulama (scholars of religion) within the state administration." 49 The practical application of laiklik in Turkey was not wholly secular in the sense of separating the state from religion. Rather, the state interacted with religion through control and reform. These peculiarities of Turkish secularism agree with $\mathrm{T}$. Asad's conceptualization of various modes of secularism, in which different sociopolitical climates generate different forms of secularism as the state takes control of religion to transform society. ${ }^{50}$

\footnotetext{
${ }^{46}$ İştar B. Gözaydın, "Religion, Politics, and the Politics of Religion in Turkey," in Religion, Politics, and Turkey's EU Accession, Palgrave Studies in Governance, Security, and Development (Palgrave Macmillan, New York, 2008), 159-76. M. Hakan Yavuz, Secularism and Muslim Democracy in Turkey (Cambridge University Press, 2009), 153. ${ }^{47}$ Yavuz, Secularism and Muslim Democracy in Turkey, 153.

${ }^{48} \mathrm{Ibid}$.

${ }^{49}$ Gözaydın, "Diyanet and Politics", 217.

${ }^{50}$ Gözaydın, "Religion, Politics, and the Politics of Religion in Turkey", 8.
} 
The Diyanet's constitutional duties were: "to carry out affairs related to the beliefs, worship and moral foundations of Islam, to enlighten Turkish society about religion and to manage places of worship." 51 Diyanet was an ideological instrument in the hands of the state, and it was tasked to act as a state apparatus regulating Islamic values in society. In this respect, the goals of the Diyanet and SADUM were very similar. Both institutions aimed to purify religion from ostensibly non-Islamic elements, control religious life and link mosques and imams to the official center. Kemalist secularism attempted to reduce Islam to an individualized religion, ${ }^{52}$ removed from public life and discourse, and establish in its place a new secular moral value system. ${ }^{53}$

In contrast to common distinctions of formal-informal Islam in scholarship on religion in the USSR, researchers of Kemalist Turkey such as Mardin, Gözaydın, and Yavuz never use formal and informal categories of Islam. The lack of "official" and "unofficial" categories for Turkish Islam is possibly related to the fact that researchers of the Turkish case have had greater access to material than the Soviet case. However, Khalid implies that the formation of the Diyanet as an official Islamic organization in Turkey inadvertently created notions of an "unofficial Islam," an area of primitive and unsanctioned religious practices under attack from the enlightened Republic. ${ }^{54}$ While categorizing Islam as official and unofficial is not accurate, it still proves difficult to avoid in the Soviet context. The severe and long-lasting assault of the atheist Soviet regime on Islam profoundly impacted Islamic discourses in Central Asia, in particular notions of

\footnotetext{
51 Gözaydın, “Diyanet and Politics”, 220.

52 Gözaydın, 217.

53 Yavuz, Secularism and Muslim Democracy in Turkey.

${ }^{54}$ Khalid, Islam after Communism, 108.
} 
state-approved and non-approved practices of religion. The details of this issue will be explored in Chapter Four.

The example of Turkey shows that the Soviet case of control over religious life was not entirely unique, where the state opposed all religions and at the same time created tools to control religion. ${ }^{55}$ The Soviet Union established and used SADUM to institutionalize all aspects of Muslim social life and to discipline Muslim society through drawing clear borders between secular and religious domains. However, in practice the distinction between secular and religious institutions was not very clear, and the Soviet type of secularism was not neutral to religion, but more intrusive.

\section{Establishment of Religious Organizations during and after the Second World War}

The Second World War marked a significant shift in Soviet attitudes and policies towards religion, as religious actors, institutions and symbols were rehabilitated and reincorporated into the socio-political arena. The Soviet administration allowed the establishment of religious institutions, such as SADUM and madrasas, and Soviet Muslim citizens were allowed to go on Hajj for the first time in 20 years.

At the height of the Second World War, Joseph Stalin allowed believers of all religions to partially restore their spiritual life. The Soviet state by the end of 1942 allowed the opening of religious associations and mosques in the cities of the USSR, in order to improve public morale during military losses. ${ }^{56}$ Accordingly, state bureaucracies

\footnotetext{
55 Khalid, 108.

${ }^{56}$ Vyacheslav A. Akhmadullin, “Patrioticheskaya Deyatel'nost' Musul'man Rossii v Gody Velikoy Otechestvennoy Voyny (Po Materialam Soveta Po Delam Religioznykh Kul'tov Pri SNK SSSR)," Vestnik Rossiyskogo Universiteta Druzhby Narodov. Seriya: Istoriya Rossii, no. 1 (2016).
} 
grew increasingly aware of the need for more experts on Eastern culture, Islam, and other topics important for cultural diplomacy with the Middle East. ${ }^{57}$ In line with SADUM, other institutions emerged that would incorporate "local religious elements" into Soviet officialdom, such as the Institute for the Study of Oriental Manuscripts (later named Institute of Oriental Studies) linked to the Academy of Sciences of Uzbekistan. The institute integrated graduates from early Soviet-era maktabs (schools) and madrasas with backgrounds in Islamic theology and law. ${ }^{58}$

Starting from 1943, four independent muftiates emerged to manage the spiritual affairs of Muslims of the USSR: The Spiritual Administration of Muslims of Central Asia and Kazakhstan SADUM (based in Tashkent), Transcaucasia (in Baku), the North Caucasus (in Buynaksk), European part of the USSR and Siberia (in Ufa). However, SADUM faced a shortage of imams to staff recently re-opened mosques. In order to train imams, the Miri Arab madrasa in Bukhara was re-established in 1945, which for many subsequent years was the only Islamic educational institution in the USSR. After the end of the Second World War, SADUM took an active part in restoring the broken ties between Soviet Muslims and the Islamic world. In 1945, a group of Soviet Muslims led by Eshon Babakhanov, the first mufti of SADUM, made the first pilgrimage to Mecca and Medina.

In 1944, the Council of Ministers of the USSR founded the Council for the Affairs of Religious Cults (CARC), a state body responsible for administering all domestic religious organizations, except the Russian Orthodox Church, and managing

\footnotetext{
57 Tasar, "Soviet and Muslim", 43.

58 Babajanov, “'Ulama'-Orientalists: Madrasa Graduates”, 84.
} 
communications between the government and religious leaders, particularly on issues requiring official permission. The CARC was an All-Union Council to oversee the relationship between religious organizations and Government. These institutional foundations of state-religion relations show an important shift in Soviet state policies and increasing interest towards Islam..$^{59}$

\section{Institutionalization of Soviet Islam: The Establishment of SADUM}

From a "bottom-to-top" perspective, the institutionalization of Islam in Central Asia developed according to the multifaceted power relations between the center and periphery, where local elites, ulama, and mollas participated in the establishment of religious institutions. Khalid argues that the idea of a central institution managing and supervising religious life in society came from the remaining ulama which survived the Great Terror of $1937-1938 .{ }^{60}$ Local ulama in Central Asia "authored a petition on the establishment of a muftiate to Mikhail Kalinin, head of the USSR Supreme Soviet."61 In other words, the initiative came from the local ulama; however, "sanction for the muftiate's subsequent establishment must have come directly from the leader (Stalin): the organization's inaugural conference ensued very rapidly". 62

Eshon Babakhanov played an important role in establishing and later managing SADUM as its first mufti. He was born in 1858 in Tashkent, then in the Kokand Khanate. His father, Ustaz Abdulmazhidkhan ibn Yunus Khoja Ishan, a famous religious leader,

\footnotetext{
59 Kirasirova, "Orientologies Compared", 24.

60 'The initiative to establish SADUM seems to have come from surviving ulama in Uzbekistan itself, who in 1943, petitioned the central government for permission to hold a conference of the ulama of all of Central Asia with the aim of establishing a central religious organization' Khalid, Islam after Communism, 112.

61 Tasar, "Soviet and Muslim", 26.

62 Tasar, 27.
} 
served as a mudarris (teacher) in the Mui-Mubarak madrasa for many years. Eshon Babakhanov studied in Bukhara's Miri Arab Madrasa, then in Kukeldash Madrasa. After graduation, the young theologian and jurist began his career as a faqih in Tashkent, which was conquered by Russia in 1865 . He ultimately became one of the most respected religious authorities in early Soviet Tashkent. However, loyalty to the new Soviet government did not save the Babakhanov family from repression. In 1928, all property of the Babakhanov family was confiscated. In 1937, Eshon Babakhanov and his son Zainuddinkhan were arrested. After some time he was released, but Zainuddin died in an NKVD camp in Buryatia in 1938.

The origins of SADUM are unclear. Tasar argues that the establishment of SADUM has not been fully described. While some Uzbek sources provide full details about how this initiative came from local ulama, the role of central authorities is muddy. For instance, Hojaniyazov, grandson of Eshon Babakhanov, claims that Babakhanov and a group of theologians visited Yuldash Akhunbabaev, Uzbek SSR chairman, in 1943. Eshon Babakhanov shared his proposals and the rationale for the creation of a religious administration for Central Asian Muslim styled after the (TsDUM) Central Spiritual Administration of the Muslims. Akhunbabaev endorsed the idea and gave official consent. On July 12, 1943, a group of theologians headed by Eshon Babakhanov sent a letter to M. Kalinin about the formation of SADUM. Soon this initiative was approved. ${ }^{63}$ These sources do not mention the role of other governmental offices or Moscow authorities. As pointed out earlier, SADUM as an (official) religious

\footnotetext{
${ }^{63}$ Usmankhodzhaev, Zhizn' muftiev Babakhanovykh.
} 
organization was not alone, and alongside other similar institutions formed part of a broader religious policy in the USSR.

In her memoirs, Sofiyo Babakhanova, daughter of Eshon Babakahanov, claims that Babakhanov met with Stalin in July 1943:

"Soon after receiving the consent of the center for the opening of the Spiritual Administration, my father and brother gathered for a trip to Moscow... In Moscow, only my father attended the reception with Stalin. Upon arrival, he said that the conversation went through an interpreter in the office of Stalin. He respectfully and kindly inquired about the mood and life of Muslims, offered to gather the Kurultai (general assembly held by an organization at certain times to discuss the issues on the agenda and to elect new boards) of Muslims, form the Spiritual Administration, call upon Muslims to assist in the war and resolutely fight against the Nazi invaders." 64

This meeting between Eshon Babakhanov and Stalin is also controversial.

According to Arapov, the meeting between J. Stalin and E. Babakhanov is not recorded in the 1924-1953 catalog of persons accepted by the first Secretary General. ${ }^{65}$ They may have met elsewhere but this is just speculation.

These accounts emphasize the role of local ulama, while neglecting the role of other state actors such as the local government in Uzbekistan. Contemporary attitudes towards Soviet history, such as movements to celebrate local national heritages and "de-Sovietize" memory through highlighting the roles of local actors over the state, tentatively explain the focus of these accounts on local Muslim ulama rather than Soviet bureaucracy. At the same time, Babajanov suggests that religious actors enjoyed

\footnotetext{
${ }^{64}$ Usmankhodzhaev, 41-42.

65 Dmitriy Arapov, Islam i sovetskoe gosudarstvo (1944-1990). Sbornik dokumentov. Vypusk 3 (Moskva: Mardzhani, 2011), 21.
} 
relative freedom after the Second World War until the Khrushchev era. ${ }^{66}$ Assuming that religious actors and organizations began enjoying such freedom and tolerance during the climax of the USSR's involvement in the Second World War, the extent of local initiative behind SADUM's origins is realistic.

E. Babakhanov personally hosted the first Kurultai of the Central Asian ulama in his Tashkent home in October 1943. The order to organize the Kurultai came from the Chairman of the Council of Ministers of the Uzbek SSR, Abdujabbar Abdurakhmanov, who invited E. Babakhanov and said: "you have received permission from Moscow to open the Spiritual Administration of Muslims of Central Asia and Kazakhstan in the city of Tashkent. Prepare for the Muslim congress (Kurultai), open the spiritual administration, and open mosques... I must tell you that the government is not able to allocate buildings for this organization. The decision on location is submitted for your consideration." ${ }^{67}$ E. Babakhanov offered to host the spiritual administration in the Hazrati Imom makhalla, an ancestral home of more than a thousand square meters with buildings, which was confiscated in 1928. The Government of the Uzbek Republic within three days decided to return the confiscated house to E. Babakhanov. ${ }^{68}$ The resolution of this affair in only three days shows that it was an important decision for the local government to support the foundation of SADUM.

The first Kurultai of Central Asian ulama formalized the creation of SADUM. E. Babakhanov, 85 years old at the time, was unanimously elected as the Chairman of

\footnotetext{
${ }^{66}$ Zilola Khalilova and Bakhtiyar M. Babajanov, "Soviet Ideology in the Madrasa: Political Contexts and Educational Practice," Islamology 7, no. 2 (2017): 29-52.

${ }^{67}$ Usmankhodzhaev, Zhizn' muftiev Babakhanovykh.

68 Ibid.
} 
SADUM and mufti of the five Central Asian republics. Murat Khoja Salehi was elected deputy chairman of SADUM, and E. Babakhanov's son Ziyauddin, then 35 years old, was appointed executive secretary. The inaugural Kurutlai appointed a representative of SADUM in each republic of the region with the rank of qazi (a judge in Sharia):

Ziyauddin Babakhanov in Uzbekistan, Abdul Ghaffar Shamsuddin in Kazakhstan, Salekh Babakalan in Tajikistan, Olimhon Tura Shakir in Kyrgyzstan, and Anna Ishan in Turkmenistan. ${ }^{69}$ Members of the assembly also planned to organize the Kurultai every five years in order to elect chairman who could issue fatwas. SADUM, was part of the bureaucratic system and it was not a legislative body. However, official fatwas issued by mufti of SADUM opened possibility of influencing Soviet Muslims through traditional methods. ${ }^{70}$

The SADUM Charter approved the rights and duties of the Board as the highest spiritual body of Muslims in Central Asia and defined the functions of central offices and representatives in the five republics. The Charter also identified the following tasks:

- to manage religious affairs and rituals through official religious associations located in Uzbekistan, Kazakhstan, Kyrgyzstan, Tajikistan, and Turkmenistan;

- to preach the foundations of Islam to believers;

- to solve controversial issues related to religious ceremonies, instruct imam-khatibs (a leader of prayers in a mosque, or the Muslim community, and a preacher of the sermon) to relay formal opinion to believers, and to publish fatwas on the above issues;

- to educate believers in the spirit of truthfulness, honesty, hard work and law-abidingness;

\footnotetext{
${ }^{69} \mathrm{lbid}$.

${ }^{70}$ Babajanov, "O fetvakh SADUM protiv 'neislamskikh obychaev"”, 1.
} 

customs;

- to lead the struggle among the clergy and believers against harmful

- to publish religious literature;

- to establish contacts with foreign Muslim organizations and represent the spiritual and secular life of Central Asian Muslims to a foreign Muslim audience. ${ }^{71}$

SADUM's central apparatus in Tashkent undertook two initial objectives: "to establish full control over all the mosques and major shrines in Central Asia, and to convince the state of its reliability as a loyal partner." 72

In order to achieve "full control" over the mosques, mosques were required to register with local representatives of the CARC. CARC reports about numbers of registered and unregistered mosques indicate that registering mosques and mollas was one of the primary means of controlling religious activity. As of 1952, 357 registered Muslim associations operated in the Soviet Union. All registered associations had affiliated mosques in Central Asia: 74 in the Uzbek SSR, 32 in the Kyrgyz, 27 in the Tajik, 20 in the Kazakh, and 4 in the Turkmen SSR. ${ }^{73}$ Around 200 people visited the Tilla-Sheikh mosque daily in Tashkent, with around 1,000 people for Friday prayers. During Ramadan in 1951, 42,000 people attended prayers in Tashkent's 16 registered mosques. In Ferghana oblast, 17,000 people visited the 4 registered local mosques for Ramadan prayers. CARC reports from 1952 also indicate officials' awareness of 55 unregistered mosques in the Uzbek SSR and 73 such mosques in the Kyrgyz SSR. CARC representatives further identified more than two thousand unregistered mollas in

\footnotetext{
71 Usmankhodzhaev, Zhizn' muftiev Babakhanovykh.

72 Tasar, "Soviet and Muslim", 27.

${ }^{73}$ Dmitriy Arapov, Islam i sovetskoe gosudarstvo (1944-1990). Sbornik dokumentov. Vypusk 3 (Moskva: Mardzhani, 2011), 99.
} 
the Central Asian republics conducting religious activities in violation of the established order: 800 in the Uzbek SSR, 524 in the Kyrgyz SSR, 440 in the Kazakh SSR, and 280 in the Turkmen SSR. ${ }^{74}$ SADUM controlled the registered mosques, and by 1952 more than half of the functioning mosques in Uzbekistan were registered. By contrast, in Kyrgyzstan, the number of registered mosques were lower than unregistered mosques. Thus, CARC and SADUM were more successful in Uzbekistan. Mosques and mollas in the other republics more often resisted the central authorities in Tashkent. The perception of SADUM as an Uzbek-dominated institution may also have motivated their resistance..$^{75}$

Similarly, in 1946, Deputy Chairman of CARC Y. Sadovski sent a letter to the representatives of the CARC in the republics about unifying the four Soviet muftiates into a single All-Union Spiritual Administration of Muslims of the USSR. ${ }^{76}$ The primary motivation behind creating a single muftiate was to resolve questions related to all Soviet Muslims from a single center, achieve better coordination among the muftis of different regions, and give equal opportunity to all Muslim organizations across different regions in sharing limited state resources. SADUM published its journal mainly for Central Asian Muslims and filled its madrasas with mostly Central Asian Muslims. The Council attempted to combine all these material resources and distribute it to the rest of the USSR. The letter also acknowledged difficulties in creating such a central religious

\footnotetext{
74 Dmitriy Arapov, Islam i sovetskoe gosudarstvo (1944-1990). Sbornik dokumentov. Vypusk 3 (Moskva: Mardzhani, 2011), 99-102.

75 Dmitriy Arapov, Islam i sovetskoe gosudarstvo (1944-1990). Sbornik dokumentov. Vypusk 3 (Moskva: Mardzhani, 2011), 53.

${ }^{76}$ Dmitriy Arapov, Islam i sovetskoe gosudarstvo (1944-1990). Sbornik dokumentov. Vypusk 3 (Moskva: Mardzhani, 2011), 45.
} 
administration, the most important of which being the "presence of a known antagonism between the clergy of the Central Asian republics of the USSR". In addition, the letter further worried that a "very acute question may arise regarding the person who will lead the center, due to the absence of an equally recognized authoritative figure". ${ }^{77}$

After approval from the Uzbek republican government and SADUM mufti E. Babakhanov, CARC representatives in the Uzbek SSR responded positively to the letter, suggesting that the head of the Central Spiritual Administration of Muslims should be chosen among Central Asians. ${ }^{78}$ Representatives from Azerbaijan also approved this project and recommended Ziyauddin Babakhanov as a candidate. However, representatives of CARC in Turkmenistan and Tajikistan opposed the idea of an All Union muftiate. The CARC Commissioner in the Turkmen SSR, N. Atabayev's response is remarkable:

In Turkmenistan there are still its own, historically established features in matters of religion and in the relations of the Turkmen people to the activities of various religious institutions and to their heads. The Turkmen population in the past did not know the [religious] norms: did not use Sharia but was guided mainly by customary law - the adat.

The attempts of former tsarist officials to normalize the life of the Turkmen population according to Sharia were not successful. The attitude towards the Sharia and its defenders among the Turkmens remained, as before, at the [low] level that various travelers to Turkmenistan observed in the years preceding the accession of Turkmenistan to the Russian Empire.

This evidence doesn't speak in defense of the project for the creation of a unified religious and administrative center, in which the Turkmen representatives professing Islam can, in many cases, be in opposition, and, on the basis of differences of opinion on a number of issues, can extremely complicate the

\footnotetext{
77 Dmitriy Arapov, Islam i sovetskoe gosudarstvo (1944-1990). Sbornik dokumentov. Vypusk 3 (Moskva: Mardzhani, 2011), 47.

78 Dmitriy Arapov, Islam i sovetskoe gosudarstvo (1944-1990). Sbornik dokumentov. Vypusk 3 (Moskva: Mardzhani, 2011), 48-49.
} 
activities of a Council alleged to be created by representatives of other nationalities practicing Islam. ${ }^{79}$

Atabayev's response revealed a troubled ethnic dimension of the relationship between SADUM (in Tashkent) and local representatives of the CARC in other Central Asian republics. Ashgabat continued to oppose such projects.

Besides registering mosques, establishing "full control" over religious activities also meant collecting funds from donations received by mosques and money paid to imams by local people for their performance of rites and ceremonies. SADUM and other similar religious institutions had to fund their activities through their own resources. SADUM supported all of its expenditures with donations collected in a socialist system, and at the same time contributed to the state budget, transferring some of the collected money to state finances. Although it seems contradictory for a state-affiliated institution to carry out such religiously-oriented economic activity within the socialist system, controlling money flows through charity and zakat (one of the pillars of Islam, the mandatory annual tax in Sharia paid from various types of income and property) played an important role during the initial operations of SADUM. ${ }^{80}$ Facing the problem of charity and zakat circulating through unregistered mosques and mollas, SADUM aimed to monitor and control the mobility of religious people and the flow of money related to religious activities.

\footnotetext{
79 Dmitriy Arapov, Islam i sovetskoe gosudarstvo (1944-1990). Sbornik dokumentov. Vypusk 3 (Moskva: Mardzhani, 2011), 52-53.

80 Tasar, "Soviet and Muslim," 34-36.
} 


\section{What was the Role of CARC in Managing SADUM?}

At the Congress of Muslim Clergy and Believers of Siberia and the European part of the USSR in October 1948, the CARC delegate emphasized freedom of conscience and state non-interference in religion in his following summary of the CARC's goals:

The Soviet state provides the necessary and equal conditions for followers of all religions in order to ensure the full possibility of worship. The Soviet authorities established the Council on Affairs of Religious Cults under the Council of Ministers of the USSR, which was entrusted with the task of communicating between the Government of the USSR and religious associations on religious issues requiring Government approval. The Council's objectives include the further normalization of relations between religious associations and the state and the timely implementation of laws on religion, without any interference into the inner life of religious organizations. ${ }^{81}$

This speech promised secularism in terms of separation between state and religious affairs. However, despite the CARC representative's rhetoric of religious freedom and the separation of religion from the state, the actual implementation of these ideas and principles took very different form. Until 1956, veteran NKVD Colonel I.V. Polyansky, with prior experience in religion suppression campaigns, directed CARC.

The objectives of CARC were most clearly defined in a 1949 report:

1) To direct the activities of religious associations in the USSR towards the narrowing of their scale and impact on society, while at the same time ensuring that religious associations strictly adhere to the separation of church and state and all other laws and resolutions of the Soviet government towards religion. 2) Restrict the activities of religious associations outside the prayer buildings to only permit worship. 3) To carry out continuous monitoring of the activities of religious centers and individual leaders in order to prevent, mitigate and completely eliminate the most harmful manifestations and forms of religious influence on society. 4) To resolutely stop the activities of all religious groups, whose dogma is anti-state, savage, or extremely mystical by nature, as well as preventing the emergence of new religious societies without registration. 5) Not to interfere with the establishment or use of international relations by some religious associations

\footnotetext{
${ }^{81}$ Dmitriy Arapov, Islam i sovetskoe gosudarstvo (1944-1990). Sbornik dokumentov. Vypusk 3 (Moskva: Mardzhani, 2011), 63.
} 
in the USSR, but only to the extent necessary to facilitate propaganda of the freedom of religion existing in the USSR. ${ }^{82}$

This report clearly shows that the relative freedom of religious organizations after the Second World War no longer existed by 1949 , as Soviet religious policy tightened again.

A secret letter from the Chairman of the CARC, Gostev, to the Central Committee of the CPSU in 1957 also shows that the CARC's duties were not only limited to "communicating between the Government and religious associations." CARC was also involved in gathering information necessary to fight against religion and spread atheism:

In order to assist the leading party and republican and regional Soviet governments in the deployment of scientific and atheistic propaganda among the population and the prevention of illegal forms of religious propaganda by religious activists and clergy, the Council recommends to observe the following:

1. To improve the quality of information provided to the leadership of regions and republics on the basis of a thorough study of the life and activities of religious associations and groups, bearing in mind that this information should help to more effectively conduct scientific atheist propaganda. ${ }^{83}$

The CARC's renewed emphasis on curtailing religious life was not simply the result of the Khrushchev era's anti-religious bent. CARC reports indicate that state restrictions on religion resumed during the late 1940s. The CARC, a state apparatus administering religious organizations, was also involved in anti-religious activities.

In practice, the relationship between CARC and SADUM demonstrated how boundaries between secular and religious affairs blurred in Soviet politics. In one

\footnotetext{
82 Dmitriy Arapov, “Musul'manskiy triptikh: Islam i Sovetskaya vlast'. 1917-1949-1982," Pax Islamica, no. 1 (2) (2009): 248-66.

83 Dmitriy Arapov, Islam i sovetskoe gosudarstvo (1944-1990). Sbornik dokumentov. Vypusk 3 (Moskva: Mardzhani, 2011), 152-153.
} 
notable incident in Uzbekistan's Termez district, the local administration violated the law by permitting the opening of a new mosque..$^{84}$ In the ensuing dialogue between Babakhanov and CARC Chairman Puzin precipitated by this incident, Puzin admonished Babakhanov to ensure that local administrations under SADUM's watch continued to adhere to law and central direction in religious issues. Here, a centralized and secular state body was willing to involve itself in local, religious matters when its authority was undermined. However, in the same conversation when Babakhanov later asked for the CARC's position on publishing a fatwa, or authoritative legal opinion, on the issue of kalym (bride price), Puzin waived involvement and insisted that local Muslim authorities resolve it. Thus, while overstepping ambiguous bounds between the separation of state and religion to monitor local religious authorities, the CARC was also willing to defer to local initiative and decisions in other places. ${ }^{85}$

\section{Conclusion}

Islam underwent substantial changes in the early to mid- $20^{\text {th }}$ century as secularist ideologies dominated the politics of many Muslim societies. However, new post-colonial scholars argue that these changes were not merely the result of colonialism, because local actors also played important roles in this religious transformation. Most notably, SADUM in Soviet Central Asia and the Diyanet in the Turkish Republic similarly exemplified the institutionalization of Islam, to an extent unprecedented in religious tradition, ${ }^{86}$ under the auspices of a centralized, secular, and

\footnotetext{
${ }^{84}$ Dmitriy Arapov, Islam i sovetskoe gosudarstvo (1944-1990). Sbornik dokumentov. Vypusk 3 (Moskva: Mardzhani, 2011), 149-150.

85 Dmitriy Arapov, Islam i sovetskoe gosudarstvo (1944-1990). Sbornik dokumentov. Vypusk 3 (Moskva: Mardzhani, 2011), 199-200.

${ }^{86}$ Khalid, Islam after Communism, 112.
} 
alternately anti-religious authority. ${ }^{87}$ This chapter demonstrated that the relationship between the local and the center in the formation of SADUM was complex and dynamic with local ulama and mollas having the initiative to organize as a group and decide on local interests at key moments.

SADUM was strictly controlled by CARC, a central state body managing all religious organizations in the USSR. CARC oversaw the implementation of religious policies, including the separation of state and religion. However, archival documents discussed in this chapter reveal that CARC was also involved in anti-religious campaigns. This dual nature of CARC exemplifies ambiguity of Soviet state and Islam relations. The Soviet state established SADUM to manage Central Asian Muslims, while also supporting anti-religious campaigns.

At the same time, the state permitted the Hajj for small groups of Muslims while accepting embassies of politicians and clerics from Islamic countries into the USSR. Foreign policy considerations motivated a somewhat different and more conciliatory state attitude towards Islam than towards other religions. The collapse of world colonialism beginning after 1945 and the emergence of independent countries with millions of Muslims forced the Soviet leadership to consider international affairs in its domestic Islamic policy. The propaganda activities of SADUM played a special role to these ends, as Tashkent, Samarkand, and Bukhara became showcases of "Soviet Islam."

${ }^{87}$ Tasar, "Soviet and Muslim", 185. 
SADUM and its religious scholars tried to push their own agendas using the space provided by the Soviet state. SADUM was not merely a creation of the Soviet state, but a result of more complex power relations between local Muslim scholars and the Soviet government. Rather than passively responding to central authority, SADUM actively contributed to domestic and, as explored in the next chapter, international developments as Islam-state relations developed in the post-war USSR. 


\section{Chapter 2: SADUM as a Diplomatic Organization}

After the Second World War, religious organizations in the Soviet Union called for "a struggle for peace," [bor'ba za mir]. Throughout the 1950s until the 1970s and 1980s, it was the most recurring message in the international correspondence, conference speeches, and publications of Soviet Muslim clergy. Foreign experts called this a new "adventure of [the] Kremlin, in their plans to dominate the world". ${ }^{88}$ For the Soviet partystate apparatus, religious proclamations for peace allowed them to solve several problems: "to maintain the myth of freedom of conscience in the USSR and to form a positive image of the Soviet state in foreign countries." ${ }^{89}$

This chapter will explore the role of SADUM in manufacturing and disseminating an Islamic image of the Soviet Union to a foreign Muslim audience. Kirasirova's approach will be used in situating the Soviet Union's relations with its eastern borderlands within the post-World War II decolonization context. This approach examines SADUM from multiple perspectives and situates SADUM at the intersection of various Soviet policies, including anti-colonialism and Soviet Orientalism. From this perspective, SADUM represented a state effort to merge anti-colonial and Islamic images of the USSR. The Soviet state delegated its diplomacy and engagement with the Middle East through its Central Asian republics, with the Khrushchev and Brezhnev leaderships involving Central Asian actors to propagate a Muslim image of the Soviets to Islamic countries. Building on this approach, this chapter argues that rather than

\footnotetext{
${ }^{88}$ Akhmadullin, "Islamskiy faktor vo vneshney politike Soyuza Sovetskikh Sotsialisticheskikh Respublik."

${ }^{89}$ Vyacheslav A. Akhmadullin, "Deyatel'nost' sovetskogo gosudarstva po privlecheniyu musul'man k bor'be za mir v 1940-kh-1950-kh gg," Vlast', no. 9 (2013), 124.
} 
imposing specific state goals of reforming Islam from the top down within this "Eastern" image, the state relied on Muslims within SADUM to define a progressive vision of Islam for the East.

\section{Was SADUM only a Showcase to the Foreign East?}

Some scholars have focused on the role of Soviet Islamic organizations such as SADUM as a diplomatic asset and located the role of Islam as a Soviet political tool in the context of controlling the Soviet East and engaging the Union's Eastern neighbors. These strategies used Soviet Muslims as a showcase to foreign Muslims demonstrating the compatibility of socialism and Islam. ${ }^{90}$ Others have claimed that this phenomenon was merely part of larger Eurasian political events. ${ }^{91}$ Relations with Middle Eastern countries during Khrushchev's period overlapped with several contemporary developments such as decolonization, the rise of liberation movements in Afro-Asian regions, and de-Stalinization, which opened opportunities for Soviet Eastern peoples, and not only for religious actors, to be integrated into foreign affairs as intermediaries and representatives.$^{92}$ Kirasirova claims that debates within institutions like the Soviet Committee for Solidarity with Asia and Africa, which included Muslim scholars, poets, and intellectuals, show that religion was rarely used as an example of shared values among the Soviet East and foreign East. Kirasirova argues that the diplomatic role given to religious actors such as SADUM was very limited. ${ }^{93}$ The officials of SADUM had

\footnotetext{
${ }^{90}$ Ro'i, The USSR and the Muslim World: Issues in Domestic and Foreign Policy. Eren Murat Tasar, "Soviet and Muslim: The Institutionalization of Islam in Central Asia, 1943-1991" (Ph.D., Harvard University, 2010).

${ }^{91}$ Masha Kirasirova, "The Eastern International: The 'Domestic East' and the 'Foreign East' in Soviet-Arab Relations, 1917-68" (Ph.D., New York University, 2014).

92 Kirasirova, 328.

${ }^{93}$ Kirasirova, 330.
} 
limited political agency compared to the other intellectuals and poets renowned as experts of the east. During international meetings, SADUM muftis had very limited space for speech. ${ }^{94}$

SADUM's foreign relations and role in diplomacy was, however, tied to its domestic role as an institution to control religious life in Central Asia. Comparing SADUM to non-religious institutions and actors, or other state organizations only involved in foreign affairs could be misleading in understanding the role of SADUM as an international actor. SADUM's exceptional position as an institution that bridged the "Soviet East" and the "foreign East" underlined its utility to the Soviet state as a means to simultaneously control the Muslim community of Central Asia and promote the USSR abroad to other Muslim countries ${ }^{95}$ Accordingly, SADUM was one of the few Islamic organizations in Central Asia and in the USSR more broadly with access to international contacts and the broader Muslim world. SADUM had control over the Hajj by preparing the list of who could attend the pilgrimage and maintained contact with Central Asian emigres abroad. The Muslim clergy was also allowed to attend international conferences, publish and distribute journals, exchange letters with foreign scholars and institutions, and send students to religious education abroad. During Khrushchev's leadership, SADUM organized its own internal and independent Department of International Relations. After 1965, during the Brezhnev years, SADUM became an increasingly important diplomatic asset. Members of SADUM learned how to game the Soviet system and use existing policies and conditions for their own benefit.

\footnotetext{
${ }^{94}$ Ibid.

${ }^{95}$ Tasar, "Soviet and Muslim", 336.
} 
Emergence of SADUM in the International Arena during the Khrushchev era

Starting from 1953 until 1964, the Soviet approach to Islam under Khrushchev became more ambivalent. This ambivalence originated from the different needs and goals between domestic and foreign affairs in relation to Islam. In the domestic sphere Islam was seen as a threat against progressive and communist values. In foreign affairs, the Soviets needed a more flexible approach to Islam, to counteract the use of Islam in anti-Soviet propaganda by other countries such as the USA and the UK. Khrushchev's ambitions to restore the Bolshevik revolution in the East thrust SADUM on to the international stage. Previously, SADUM suffered intense pressure, but it did not disappear, under Khrushchev's earlier anti-religious campaign. The government's ambivalence towards religion put SADUM in a position of having to constantly prove its loyalty to the party-state. Yet, the fact that it survived initially harsh anti-religious policies proved its utility for the Soviet state in domestic and foreign matters.

In foreign affairs, Khrushchev's government supported anti-colonial struggle and Muslim populations constituted a sizable part of colonial and post-colonial countries in Asia and Africa. Hence, as the de facto leader of the muftiates, SADUM appeared as a valuable resource in international affairs. According to Tasar and Roi, SADUM benefited from Khrushchev's anti-colonial policies and gained more influence during this period. Thus, after the Second World War, competition among Western powers for influence over the Middle East and the Soviet anti-colonial struggle played important roles in the emergence of SADUM as a diplomatic institution. The Soviet Union used international Muslim conferences abroad and visits of foreign delegates to local mosques as spaces to express its political interests. In 1952, Ziyauddin Babakhanov, Deputy Chairman of 
SADUM at the time, and Ali-Zadeh, Chairman of the Spiritual Administration of Transcaucasia, participated in an international conference of ulama in Pakistan, representing the Muslims of the Soviet Union. One of the conditions of the Soviet government was that "these persons be accompanied by a specially appointed secretary". ${ }^{96}$ The intelligence services likely appointed their accompanying secretary, as was typically the case in all international travels for Soviet officials. The Foreign Ministry and the Council for Religious Affairs under the Council of Ministers also noted that the "representatives of the USSR could use their participation in this conference to speak out in defense of peace and friendship among nations, for the right of nations to selfdetermination, for strengthening the independence of Muslim countries, and also to acquaint the conference with the existing freedom of religion in the USSR and talk about the cultural and economic growth of the Soviet national republics." 97

96 Dmitriy Arapov, Islam i sovetskoe gosudarstvo (1944-1990). Sbornik dokumentov. Vypusk 3 (Moskva: Mardzhani, 2011), 112-13.

${ }^{97}$ Dmitriy Arapov, Islam i sovetskoe gosudarstvo (1944-1990). Sbornik dokumentov. Vypusk 3 (Moskva: Mardzhani, 2011), 112. 


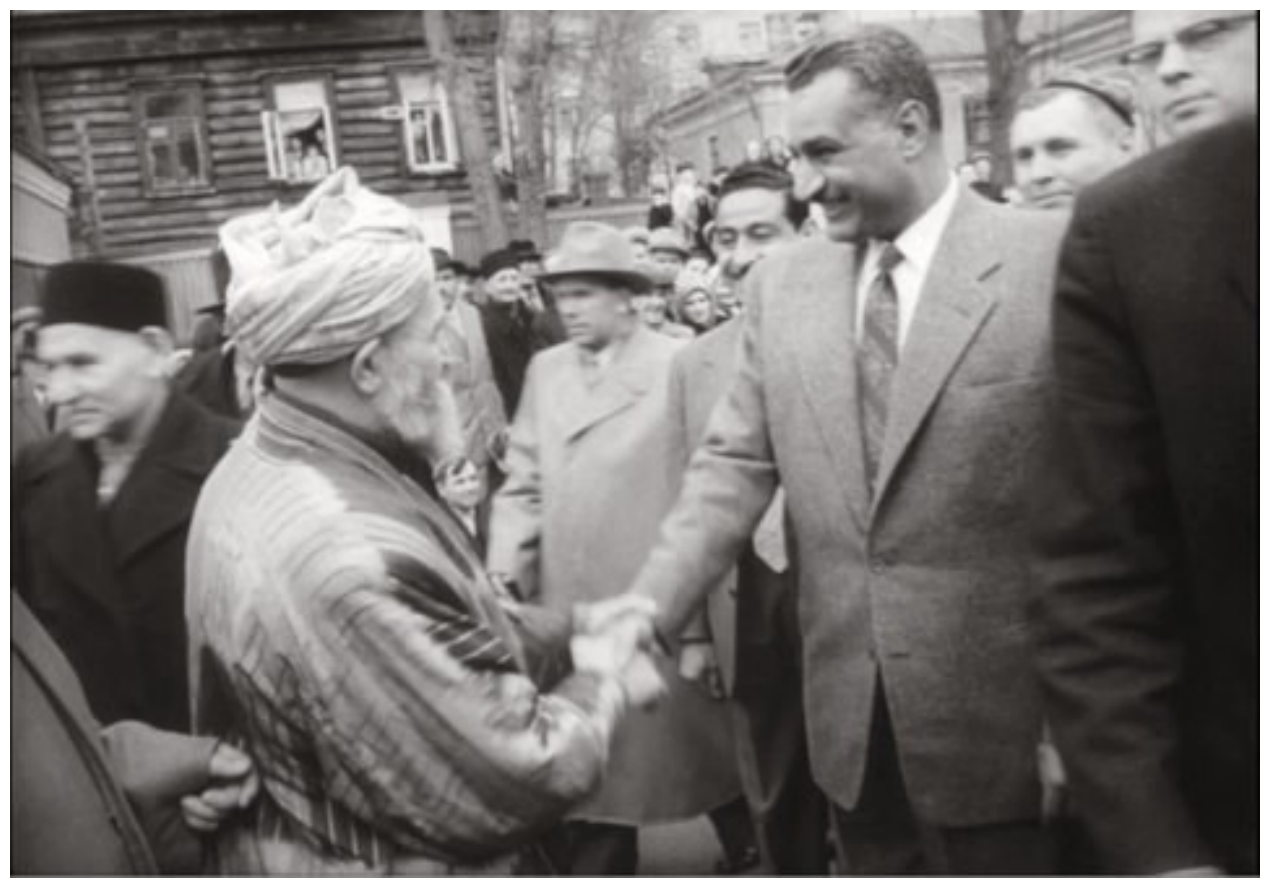

Picture 1. Imam-Khatib Kamaritdin Salikhov meets President Gamal AbdelNasser in the courtyard of the Moscow Cathedral Mosque, 1958. ${ }^{98}$

In 1958, Gamal Abdel-Nasser ${ }^{99}$ visited Moscow. During a visit to the Moscow Cathedral Mosque [Sobornaya Mechet], Imam-Khatib of the mosque, K. Salikhov, gave a speech which demonstrated how Soviet Muslim clergy positioned the Soviet Union within an Islamic discourse and promoted it to an international Muslim audience:

Present at today's prayer service in our Cathedral mosque, the distinguished guest Gamal Abdel Nasser and his companions have worked hard to liberate the oppressed Arab peoples from the colonizers, and in accordance with the instructions of Allah Almighty, have shown patience and endurance in overcoming difficulties and achieving their goal. Of course, for deliverance from powerful enemies like the capitalists, they needed the help of true friends. They found them in the country of the Soviet Union, be well aware of this. Glory to Allah Almighty!

\footnotetext{
${ }^{98}$ Kadr kinokhroniki, Gazeta Medina al'-Islam “Minbar Islama № 239 Spetsvypusk / Sentyabr' 2015 Istoriya Moskovskoy Sobornoy mecheti", http://www.idmedina.ru/medina/?6540

${ }^{99}$ The president of United Arab Republic in 1954-1970. UAR, was the name of Egypt from 1958 until 1971. He also led the formation of a pan-Arabic unity United Arab Republic with Syria, from 1958 until 1961. In 1962, he started socialist reforms.
} 
We, the Muslims of the Soviet Union, living a peaceful and happy life, thank the freedom granted to us by our government, offer our prayers to Allah Almighty in this mosque in the days of the attacks of the aggressors on our Arab Muslim brothers and, thanks to our brothers who were subjected to aggression, collected in one day, thank God, 40,000 rubles in money. We are happy that we live under the leadership of the Government, which provides humanity and support to oppressed peoples, without distinction of race, nationality or religion. So, just as the great prophet Muhammad found support from the ruler of a neighboring country while under persecution; our Arab brothers too found their true friend in the Soviet Union. This circumstance caused concern among the aggressive capitalist circles, and they made various promises, including dollar handouts, slandering the Soviet Union and trying to mislead the Arab peoples from the Soviet Union, to discredit the Soviet Union in their eyes. 100

In the speech supported with verses from Quran, the imam depicted the Soviet Union as a sanctuary and a protector of the oppressed Muslims. This narrative referenced an important historical event in the Islamic tradition, when the first group of Muslims, suffering persecution in Mecca, fled to Ethiopia under the protection of the local Christian king. In the words of the imam, the Soviet Union was playing the same role for oppressed Muslims on a global scale in the $20^{\text {th }}$ century. Now the oppressors were the imperialist West, and the protector was the Soviet Union. This narrative shows how the Soviet Union used Muslim clergy in an attempt to promote itself as the protector and supporter of Islam on the international stage. It also demonstrates how the Soviet official clergy used religious symbols for geopolitical purposes. Official Muslim clergy used Islamic sources and messages to promote the Islamic image of the Soviet Union to the Muslim world. Islamic discourse became a space to manage international politics and relations. The religious discourse was used to get sympathy from the regions where the Soviet state had political and economic interests.

\footnotetext{
100 Dmitriy Arapov, Islam i sovetskoe gosudarstvo (1944-1990). Sbornik dokumentov. Vypusk 3 (Moskva: Mardzhani, 2011), 174.
} 
SADUM worked together with CARC to develop a specific image of Islam in the Soviet Union for foreign audiences. It included carefully selected structures, sites, mosques and personalities that represented a progressive Islam in Soviet Central Asia. Certain local religious practices were deemed inauthentic such as shrine visits and itinerant mollas. In 1956, CARC requested the local representatives to prepare a list of sites and mosques appropriate for foreign delegation visits. In response, local officials in Osh recommended the city's mosques for their recent renovations, which would "give visitors the impression that our [i.e. the Soviet Union's] mosques are very well taken care of."101 SADUM's headquarters in Tashkent ironically was not considered good enough to show foreign visitors, as "the streets and roads leading to the building were narrow, the premises bad and crooked, and due to recent heavy rains, many walls and buildings fell apart." ${ }^{102}$ When Egyptian President Nasser visited Tashkent in 1958, he met with the muftiate's leaders not at SADUM's headquarters but at a more convenient place in the city, chosen to give Nasser a better impression. ${ }^{103}$

Central Asian Muslims approved to interact with foreign visitors were also closely selected according to their personal past, behavior, and habits, which included progressiveness, sound political opinions, culturedness, respect among the community, piety, lack of fanaticism, reading newspapers, and understanding questions related to the international affairs. ${ }^{104}$ One of the CARC officials noted in a 1958 memo:

Among the pilgrims who went to Mecca last year from the Soviet Union, there were individuals who, due to their level of development, might have

\footnotetext{
101 Tasar, "Soviet and Muslim", 358.

102 Tasar, 359.

103 The exact place of the meeting is unknown. For more details, see Tasar, 359.

104 Ibid.
} 
given the wrong impression about Muslim life in the USSR to Muslims in other countries. The representatives must give this aspect of things serious attention, so that the Hajj would offer specific positive political results to the state, in addition to fulfillment of the believers' religious obligations. ${ }^{105}$

In response, one of the representatives of CARC in Kyrgyzstan, Akhtiamov, recommended someone from Jalalabat, because he was "a cultured person who knows the Russian language well and is educated." In another case, Akhtiamov recommended another person based on "fluency in Russian and Uzbek as a positive quality."106 Officials' attention to individual "level of development" (as criteria for approval) seemingly focused on education, particularly fluency in Russian and Uzbek, and perhaps even Persian and Arabic.

Moscow was also aware of the diplomatic use of religious actors to respond to social and political developments in the Islamic Middle East. A 1958 letter from CARC chairman Puzin to Secretary of the CPSU Central Committee Nuritdin Mukhitdinov ${ }^{107}$, expressed worry at the impact of religious revival in the Middle East, and requested an extensive plan "on the use of Muslim and other religious organizations of the USSR in order to strengthen Soviet influence in the countries of the East":

The reactionary circles of the United States, Britain and other countries make extensive use of religious organizations and their leaders to strengthen and expand their influence in foreign countries, and especially in the countries of the East. They actively use these organizations also for the purpose of anti-Soviet propaganda.

\footnotetext{
105 Tasar, 361.

106 Ibid.

${ }^{107}$ Mukhitdinov Nuritdin Akramovich (1917-2008) - Soviet party leader. In 1955-1957, First Secretary of the Central Committee of the Communist Party of Uzbekistan. In 1957-1961, Secretary of the Central Committee and member of the Presidium of the Central Committee of the CPSU. Later appointed to various posts, including in 1968-1977, as USSR ambassador to Syria.
} 
Religious organizations of the USSR can, to a certain extent, counteract this propaganda and, for their part, interrupt the reactionary circles of foreign countries. Moreover, with the skillful direction of their activities, religious organizations of the USSR can become one of the effective channels of Soviet influence in the countries of the East and in some other foreign countries. However, this channel of our penetration abroad has so far been underestimated and was used poorly. ${ }^{108}$

The letter continues with a detailed plan for exchanges with foreign religious institutions like Al Azhar University and important religious figures from Middle Eastern countries, as well as a plan of publications, journals and documentaries about Muslim life in the Soviet Union intended for foreign audiences.

In the same letter, Puzin raised the question of organizing an international relations department within the CARC to manage the use of domestic religious organizations in foreign policy. This department was initially planned to start in August 1950, answering to the leadership of the USSR, and responsible for studying foreign religious organizations and overseeing the participation of Soviet citizens in religious events abroad. However, implementation was delayed several times. ${ }^{109}$

The proposal was not implemented until 1961, but the department was not established within CARC, but rather under Z. Babakhanov's initiative, as a division for international relations within SADUM. ${ }^{110}$ The next year, the CARC published a report on the participation of the Soviet Muslim delegation in the World Islamic Congress, held in

\footnotetext{
108 Dmitriy Arapov, Islam i sovetskoe gosudarstvo (1944-1990). Sbornik dokumentov. Vypusk 3 (Moskva: Mardzhani, 2011), 166.

${ }^{109}$ Vyacheslav A. Akhmadullin, “Otdel mezhdunarodnykh svyazey musul'manskikh organizatsiy SSSR v strukture Soveta po delam religioznykh kul'tov: opyt sozdaniya i normativnye osnovy deyatel'nosti," Islamovedenie 7, no. 2 (2016).

110 Ibid.; https://www.alexanderyakovlev.org/almanah/almanah-dict-bio/1022779/1
} 
May-June 1962, in which Puzin suggested that CARC should establish a broader international department responsible for all Muslim organizations in the Soviet Union:

Allow the Muslim organizations of the USSR to agree among themselves on the creation, following the example of the external department of the Moscow Patriarchate, of a permanent body - the department of international relations, which would be engaged in ongoing work concerning the external activities of the spiritual departments of Muslims of the USSR: the study of Muslim organizations of foreign countries and their leaders; establishing necessary contacts with them; preparing for publication and distribution abroad of journals and books about the life of Muslims of the USSR, etc. The structure of the working apparatus of this department can include quite reliable, well-trained secular citizens of the USSR. The USSR Muslim organizations can finance the above activities well. ${ }^{111}$

The Department of International Relations of Muslim Organizations within CARC was established during a late October 1962 conference of Soviet Muslims in Tashkent. Officially, the head of SADUM, Z. Babakhanov, became the Chairman of the Department, and the chairmen of the three other Soviet muftiates became his deputies. But the staff of CARC primarily carried out the actual work of the department. On December 25, 1962, CARC appointed its own Council member, B.S. Rzhanov, as head of the Department, ranking above Chairman, Z. Babakhanov. ${ }^{112}$ The change of roles and positions reveal hierarchical nature of the CARC and SADUM relations. The Department's tasks were:

to prepare proposals and recommendations on issues of contacts and relations between Muslim religious organizations of the USSR and foreign Muslim organizations and their leaders; studying Muslim and other foreign presses; preparing drafts of materials exposing the misinformation of foreign propaganda against the USSR; preparing materials about the life of Muslims of the USSR for distribution abroad; servicing foreign Muslim

\footnotetext{
${ }^{111}$ Dmitriy Arapov, Islam i sovetskoe gosudarstvo (1944-1990). Sbornik dokumentov. Vypusk 3 (Moskva: Mardzhani, 2011), 227-228.

${ }^{112}$ Akhmadullin, "Otdel mezhdunarodnykh svyazey musul'manskikh organizatsiy", 34.
} 
figures arriving in the USSR; organizing the travel of Muslim leaders of the USSR abroad. ${ }^{113}$

The Department further stated that "The international activities of religious organizations ... is the only area where the clergy can benefit the Soviet state."

The establishment of an independent international relations department for Muslim organizations demonstrates that the Soviet state understood the importance of using religious organizations in foreign affairs. The Soviet official ulama played an important role in this respect. The foreign policy activities of CARC prioritized Islam over other religions. Notably, it did not create similar, specialized departments to manage the foreign relations of other faiths in the USSR. The department had its own accountant, was allocated a separate building, and allowed to buy a "dacha", demonstrating its special status and expectations under the party-state. ${ }^{114}$ It should also be noted that in December 1965, the Council for the Affairs of Religious Cults and the Russian Orthodox Church were transformed into a single body, the Council for Religious Affairs under the Council of Ministers of the USSR (CRA).

The authorities encouraged the international activities of Muslim organizations and SADUM for their high political dividends. ${ }^{115}$ The state encouraged Soviet Muslim clergy to build relationships with the most influential figures of the Muslim countries which they visited, and Soviet clergy's speeches were broadcast through radio stations and published in newspapers. SADUM also maintained international correspondence

\footnotetext{
113 Dmitriy Arapov, Islam i sovetskoe gosudarstvo (1944-1990). Sbornik dokumentov. Vypusk 3 (Moskva: Mardzhani, 2011), 228.

${ }^{114}$ Akhmadullin, "Otdel mezhdunarodnykh svyazey musul'manskikh organizatsiy", 36.

${ }^{115}$ Akhmadullin, "Islamskiy faktor vo vneshney politike Soyuza Sovetskikh Sotsialisticheskikh Respublik."
} 
and journalistic activities, albeit under the strict control of the Soviet state. In 1968 SADUM began publishing Muslims of the Soviet East, a monthly journal in Arabic, English, French and Uzbek. ${ }^{116}$ The journal's primary audience was foreign, promoting the Soviet way of life and the material achievements of the Soviet East, as well as publicizing the freedom of conscience in the Soviet Union. ${ }^{117}$ The initial number of journals circulated was 8,000 copies, later reaching 30,000 copies.

The first English print of the journal's first volume opens with a scenic description of SADUM's Tashkent location.

The tallest structure in the neighbourhood is the minaret of the Tilla Sheikh mosque. Opposite it looms the cupola of the "Barak-khan" madrasa, where according to religious legend, there once lay the hair of the Prophet. "Barakkhan" is a capital within a capital -the Islamic centre of the Soviet East with the Muslim Religious Board of Central Asia and Kazakhstan operating on its territory.

\footnotetext{
${ }^{116}$ There is a confusion around the starting date of the journal. Babajanov argues it started in 1947. Ahmadullin, based on archival documents, more plausibly argues that SADUM published three different journals in different time periods, and Muslims of the Soviet East started in 1968. Vyacheslav A. Akhmadullin, "Deyatel'nost' PartiynoGosudarstvennogo Apparata SSSR i Dukhovnogo Upravleniya Musul'man Sredney Azii i Kazakhstana Po Izdaniyu i Rasprostraneniyu Musul'manskikh Zhurnalov v 1945-1991 Gg," Vestnik Dagestanskogo Gosudarstvennogo Universiteta 4 (2014): 97-105.

${ }^{117}$ The Uzbek edition of the journal was printed in Arabic script, which even most educated Soviet citizens could not read, suggesting that officials were wary of communicating the journal's international messages to an internal audience.
} 


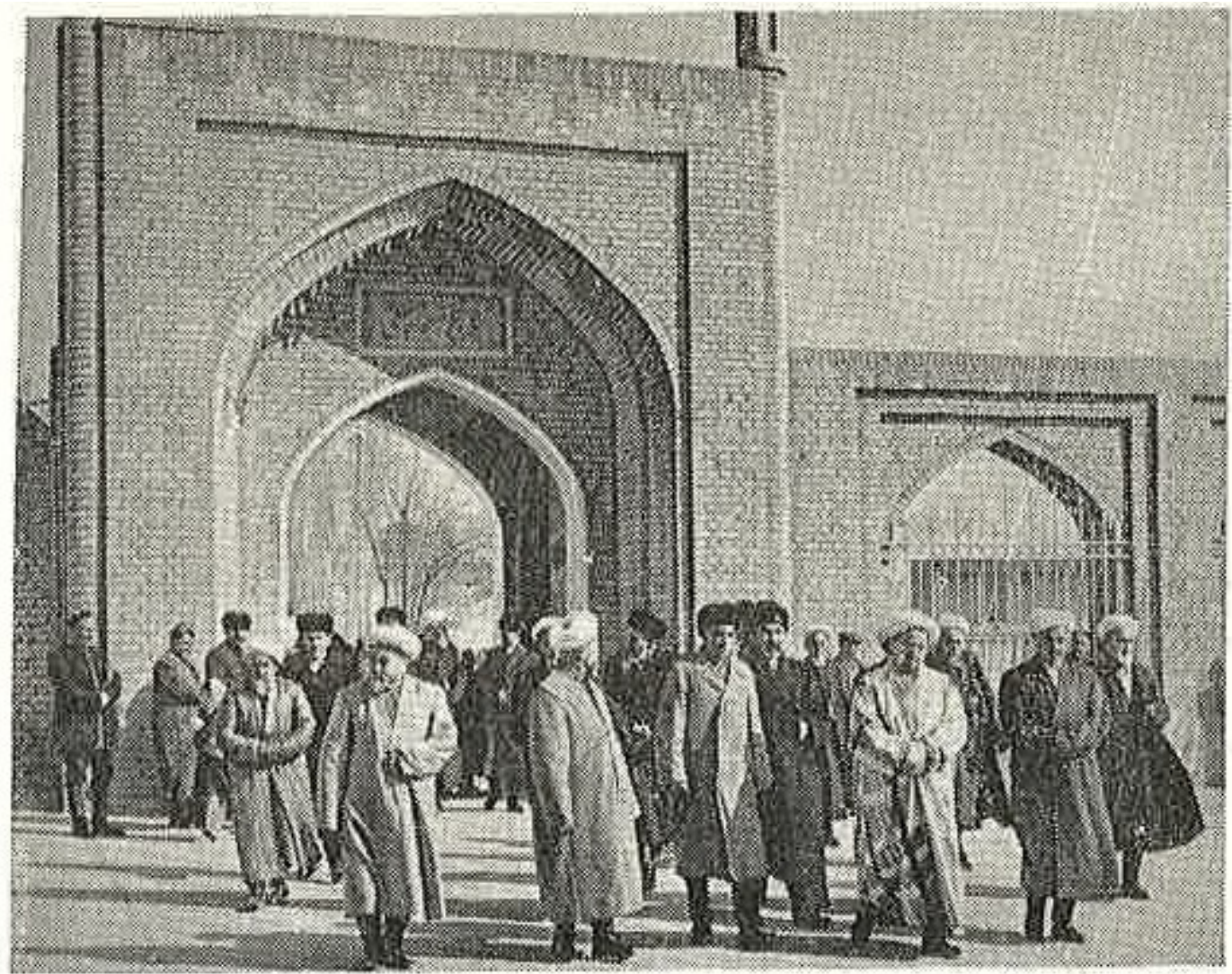

Picture 2. Main entrance to the Tilla Sheikh mosque in Tashkent ${ }^{118}$

The picture of the Tilla Sheikh mosque and its congregants in traditional dress depicted the "Islamic center of the Soviet East." The journal promoted this Islamic image of the Soviet Union to an international audience. The volume also includes reports on how foreign visitors "acquainted themselves with the life of the Soviet Muslims which gives them a true idea of the situation of Islam in the USSR."119 It quotes Khadji Muhammed Hussein, chairman of the Democratic Union Party of Somalia, writing in May 1965: "It gave me great pleasure to attend services at the Tilla Sheikh mosque. Allegations that Muslims in the Soviet Union are persecuted are absolutely unfounded. I

\footnotetext{
${ }^{118}$ Muslim Religious Board for Central Asia and Kazakhstan, "Muslims of the Soviet East," Muslims of the Soviet East 1 (1968), 3.

${ }^{119}$ Muslim Religious Board for Central Asia and Kazakhstan, "Muslims of the Soviet East," Muslims of the Soviet East 1 (1968), 13.
} 
have seen with my own eyes that they freely perform their duties and that the rights of the believers are guaranteed". ${ }^{120}$ Soviet publications often cited the remarks of foreign delegates to inform foreign audiences about the freedom of conscience in the USSR.

\section{To Game the Soviet System during the Brezhnev era}

Starting from 1965, during Brezhnev's rule, officials tempered the anti-religious campaign of 1959-1964 through adopting a more consistent bureaucratic apparatus and standardized implementation so that anti-religious propaganda and measures "penetrated Muslim life in a low-key but omnipresent fashion." ${ }^{21}$ This change of attitude reflected domestic policies towards Islam, while in foreign affairs, Moscow continued to portray the material achievements of Soviet Muslims to foreign Muslim audiences as proof of the superiority of the Soviet life and the compatibility of socialism and Islam.

Despite operating under an authoritarian party-state, SADUM and other similar local actors still had agency through various tactics to negotiate and extract concessions from above for their own benefit. At the same time, the state's use of Central Asia as a positive international showcase for foreign audiences eased political pressures on local religious actors. Taking advantage of these relaxed conditions, contemporary documents show how muftiate officials and local imams often cited foreign visitors in their requests to central authorities, such as when petitioning for mosque construction and renovations to satisfy the needs and interests of foreign

\footnotetext{
${ }^{120}$ Muslim Religious Board for Central Asia and Kazakhstan, 13.

121 Tasar, "Soviet and Muslim", 253.
} 
guests. SADUM Chairman Z. Babakhanov addressed the following 1972 letter to the

CRA to appeal for the renovation of world-famous Bukhari mausoleum.

It is known that the great Central Asian Muhaddis [a scholar dealing with the Hadiths and their methodology] and the theologian of the 9th century, Imam Bukhari, is very popular in the Muslim world - his personality is known to most Muslim men of our time. The fact that his burial place is here in the Soviet Union was for many of them a big surprise. For this reason, many of the overseas Muslims visiting our country tend to visit the tomb of Imam Bukhari. Some of the foreign tourists visiting Samarkand are also making a trip to the mausoleum of Bukhari. And for delegations invited by the Spiritual Administrations, the mausoleum became an important site for visits.

The fact is that the mausoleum has not yet acquired official status. The mausoleum is controlled and guarded by the organization for the protection of monuments. Because of this, in our endeavors to prepare the mausoleum and carry out repair works, we encounter various administrative difficulties. Moreover, such a state of the mausoleum creates a lot of difficulties during the visit of foreign guests: it is necessary to organize the cleaning of the premises before their arrival. After the departure of foreigners, we have to take all this property, including carpets back to Samarkand. Most likely these operations and preparations look like a fraud to foreigners. By the way, the residents of Samarkand began to talk about this [the "fraud"] more often.

At the same time, I would like to add that the official opening of the mausoleum does not entail an increase in the religious sentiment among believers. ${ }^{122}$

SADUM leaders wanted full control over the mausoleum of Bukhari. The letter's reasoning reveals important factors about state-religion relations and how Muslims perceived state policies. Babakhanov stressed the importance of the Soviet Union's image in foreign eyes, while offering assurance that the public opening of the mausoleum would not increase religious sentiment among believers. Babakhanov's letter revealed the conditions in which Central Asian clergy negotiated with Moscow.

122 Dmitriy Arapov, Islam i sovetskoe gosudarstvo (1944-1990). Sbornik dokumentov. Vypusk 3 (Moskva: Mardzhani, 2011), 259. 
Local religious officials responded to the control of intrusive secular authority, despite its official rhetoric of freedom of conscience, over all aspects of religious life by appealing to the secular state's own domestic and diplomatic goals towards the Soviet and foreign Orients.

Similarly, a letter from the Chairman of the CRA V.A. Kuroyedov to the Chairman of the Council of Ministers of the Uzbek SSR, N. D. Khudaiberdiev, requested a new madrasa in Bukhara. Kuroyedov argued that the "existing premises of the [current] Bukhara madrasa and the Tashkent Islamic Institute have made a negative impression on numerous foreign delegations, which is used by opposing parties to slander the Soviet state and its policies regarding religion and the church." By the 1970s and afterwards, the official Muslim clergy learned how to game the Soviet system. They appealed to existing foreign policies for their own benefit. In their reports about the Hajj, they used similar logic in order to increase the number of people allowed to go. SADUM and CRA documents noted that foreigners frequently criticized the low numbers of Soviet citizens participating in the Hajj.

In 1979, SADUM held two events of an international character. A conference dedicated to the 10th anniversary of the Muslims of the Soviet East journal was held in July in Tashkent. Religious leaders from Lebanon, Jordan, Iraq, Iran, India, Turkey, Tunisia, Pakistan, Ethiopia, Kuwait, Japan, and Bulgaria participated. In September 1979, an international Islamic symposium was held in Dushanbe on the theme "The contribution of Muslims of Central Asia, the Volga region and the Caucasus to the development of Islamic thought, to the Cause of Peace and Social Progress", in which Muslim leaders from more than 20 countries participated. In both conferences, 
participants expressed support for the USSR's foreign policy, praised Soviet Muslims for their activities in disseminating information about the life of Muslims in the USSR and strengthening international friendship, and called upon Muslims for unity in the struggle for peace. However, the next year this positive international image of the USSR was severely damaged, due to the Soviet invasion of Afghanistan.

\section{After the Soviet Invasion of Afghanistan}

The international context played an important role in state-Islam relations. Soviet officials continued to be ambivalent towards Islam in the Brezhnev era. On one hand Islam was perceived as an ally for the revolutionary cause, a political fore with mobilizational power which could be used to promote socialist ideals. On the other hand, other Soviet officials saw Islam in international politics as counter-revolutionary and incompatible with socialism. Brezhnev's 1981 report at the XXVI Congress of the CPSU demonstrates how state officials interpreted Islamic tendencies in the Middle East, which clearly indicates that the international context influenced domestic stateIslam relations:

In some countries of the East, Islamic slogans have been actively promoted recently. We, Communists, respect the religious beliefs of people professing Islam, like other religions. The main thing is what goals are pursued by the forces proclaiming certain slogans. Under the banner of Islam, the struggle for liberation can unfold. This is evidenced by the experience of history, including more recent history. But it also shows that Islamic slogans can operate as a reaction that raises counter-revolutionary revolts. The essential issue, therefore, is what the real content of a movement is. ${ }^{123}$

\footnotetext{
${ }^{123}$ Otchet Tsentral'nogo Komiteta KPSS XXVI S"yezdu Kommunisticheskoi Partii Sovetskogo Soyuza i Oocherednyye Zadachi Partii v Ooblasti Vnutrenney i Vneshney Politiki, http://ffke1975.narod.ru/s/s5/1981/rep-1.htm
} 
This report followed the Soviet invasion of Afghanistan and the Iranian revolution. Thus, international developments regularly tilted the ambivalence of Soviet officials' attitude towards Islam in international politics between optimism and alarm. The end of the 70s marked a number of significant failures for the USSR in implementing its foreign policies in the Muslim East.

The 1979 Soviet invasion of Afghanistan marred Soviet-Middle East relations and provoked strong reactions from religious organizations across the Muslim world. The following documents indicate clearly the extent of the damage it had on the Soviet foreign relations with the government and religious authorities of Muslim countries.

In September 1980, SADUM and other Muslim organizations of the USSR organized another conference in Tashkent under the motto "The $15^{\text {th }}$ century of the hijra should become the century of peace and friendship between peoples." Boycotters of the conference harshly criticized the invasion of Afghanistan and expressed severe skepticism towards Soviet international rhetoric of a struggle for global peace. The notes and minutes of Tunisian prime minister Mustafa Kamal At-Tarzi, who refused an invitation to the September 1980 Tashkent conference, indicated that earlier in June 1980, diplomats from Morocco, Algeria, Iraq, and Indonesia discussed boycotting an Islamic conference in Soviet Central Asia in response to the invasion of Afghanistan. High-level Moroccan and Kuwaiti officials in Islamic Affairs ministries publicly refused to attend the September conference. Even the Secretary General of the World Islamic 
Congress, Sheikh Muhammad Ali Al-Harakan, announced a boycott of the Tashkent conference to protest Soviet actions in Afghanistan. ${ }^{124}$

At-Tarzi also emphasized that regardless of whether the Tunisians would participate or not in the Tashkent conference, he was determined to continue "to maintain friendship and cooperation with his friends from the Soviet Union and especially with Mufti Ziyauddin Babakhanov."125 The Tunisian prime minister's determination to maintain friendship with Z. Babakhanov, despite diplomatic failure in the Soviet Union - Middle East relations, indicates the personal influence of the Mufti Babakhanov on international Muslim individuals. This incident shows how the international political situation affected the diplomatic relations between religious organizations. In a short period of time, the invasion significantly damaged the influence that the USSR accumulated in the Islamic world since the Second World War.

Seeking to rebuild its positive international image, correspondence between the CRA and Soviet diplomatic ambassadors indicates that the Soviet Union relied on Soviet Muslims to reestablish trust with Muslim countries. CRA Chairman V.A. Kuroyedov clearly expressed these aims in the following 1980 letter to Soviet ambassadors in the Muslim world:

The Council [i.e. CRA], in particular, has been instructed to significantly promote the active expansion of contacts between Soviet Muslims and foreign co-religionists, to increase their influence on them in the interests of peace and friendship among nations, to fundamentally improve international information, and to make it operational and effective. In response to the active invasion of Islam into the sphere of politics in many

\footnotetext{
124 Dmitriy Arapov, Islam i sovetskoe gosudarstvo (1944-1990). Sbornik dokumentov. Vypusk 3 (Moskva: Mardzhani, 2011), 403.

125 Dmitriy Arapov, Islam i sovetskoe gosudarstvo (1944-1990). Sbornik dokumentov. Vypusk 3 (Moskva: Mardzhani, 2011), 403.
} 
countries, recent events in Iran and Afghanistan, and imperialist attempts to inflame religious-nationalist sentiments in the USSR, the Muslim organizations of the USSR, with the assistance of the Council for Religious Affairs, are taking measures to improve their work, aimed at countering unbridled anti-Soviet propaganda.

We proceed from the need to significantly expand relations with international, regional, and Islamic organizations, and prominent and influential figures of Islam, and to actively use them to familiarize the foreign public with Soviet reality. ${ }^{126}$

The state's increased use of Soviet Muslims to improve exchanges with Middle Eastern Muslim organizations, universities, and public figures demonstrates the recognition that SADUM received within the Soviet state as an Islamic institution.

Significantly, the letter also perceived religion as a rising diplomatic force. The Soviet muftiates gained relatively more autonomy over their religious activities and assumed increased diplomatic roles in the 1980 s as the official attitude towards religion changed again. In May 1982, Moscow hosted the World Religious Forum on "Nuclear Catastrophe." Around 600 delegates and guests from 90 countries took part in its work, including leaders of religious associations, theologians, and ministers of religious affairs. With the death of mufti Ziyauddin Babakhanov in 1982, his son Shamsiddin Babakhanov was elected as the head of SADUM.

Shamsiddin Babakhanov's profile exemplifies the diplomatic role of religious actors during the 1980s. He was educated in Egypt's Al Azhar University and spoke Uzbek, Russian, Arabic, Persian, and English. His career started in the Department of International Relations of Muslim Organizations in Moscow in the early 1960s. He

\footnotetext{
${ }^{126}$ Dmitriy Arapov, Islam i sovetskoe gosudarstvo (1944-1990). Sbornik dokumentov. Vypusk 3 (Moskva: Mardzhani, 2011), 408.
} 
continued to work at the same department until the late 1970s. Over the period of his work in the Department, he established strong relations with foreign countries, took an active part in receptions, and accompanied foreign guests on visits around the country. He repeatedly went on foreign business trips as part of a delegation of Muslim organizations to participate in the work of international religious forums, helping him to develop personal contacts with religious and public figures from other countries. He was a member of the organizing committee of important international conferences hosted in the USSR and was elected a member of a number of international organizations, such as the World Peace Council, the World Supreme Council on Mosques, the Committee of Solidarity of Asian and African Countries, the Soviet and Uzbek Committees for the Defense of Peace, and the Soviet and Uzbek Peace Foundations. ${ }^{127}$

\section{Conclusion}

This chapter explored the Soviet Union's relations with its eastern borderlands within the post-colonial "Eurasian context". This approach situates SADUM at the intersection of various Soviet policies, namely anti-colonialism and Soviet Orientalism. SADUM played a significant role in proving and communicating the Soviet anti-colonial and Islamic images to foreign "Eastern" audience. The Soviet state attempted to change its image in the Middle East by incorporating and recruiting Central Asian Muslims in international affairs. This approach explains how the Soviet state, during Khrushchev and later under Brezhnev's leadership, involved Central Asian actors to propagate a Muslim image of the Soviets to the Middle Eastern countries.

\footnotetext{
${ }^{127}$ Usmankhodzhaev, Zhizn' muftiev Babakhanovykh.
} 
In contrast to Kirasirova, who argues that religious actors were only a small part of this Eastern diplomacy, this chapter argues that religious exchanges were an important part of Soviet - Middle Eastern diplomatic relations. SADUM became an asset in international affairs during 1953-1964, due to Khrushchev's ambitions to restore the Bolshevik revolution in the East. In 1961, a separate Department of International Affairs for Muslim Organizations was established within CARC. The department opened new opportunities for SADUM in their relationship with the outside world. SADUM started to publish the journal, Muslims of the Soviet East, in English, French, Arabic and Uzbek to inform the foreign audience about freedom of conscience in the USSR.

Also, the Soviet state departed from its initial anti-religious policy after the Second World War and opened spaces for Islamic scholars in the Soviet Institute of Oriental Studies in Tashkent. This chapter focused on SADUM as an Islamic institution within the Soviet Union, which was not a contradiction for the Soviet state, but a strategy to create a Soviet image harmonizing socialist and Islamic elements. Secularization on the one hand and promoting a modernized vision of Islam on the other is a result of the Soviet Union's attempt to harmonize between the "Soviet East" and the "foreign Eastern" countries. By examining how SADUM was used internationally, the chapter analyzed the space for agency within Soviet policies of religious control in Central Asia. The last generation of Muslim clergy such as Shamsiddin Babakhanov clearly represents that Soviet authorities achieved certain level of success in training religious cadres with high-level diplomatic profiles. 


\section{Chapter 3: Soviet Official Madrasas}

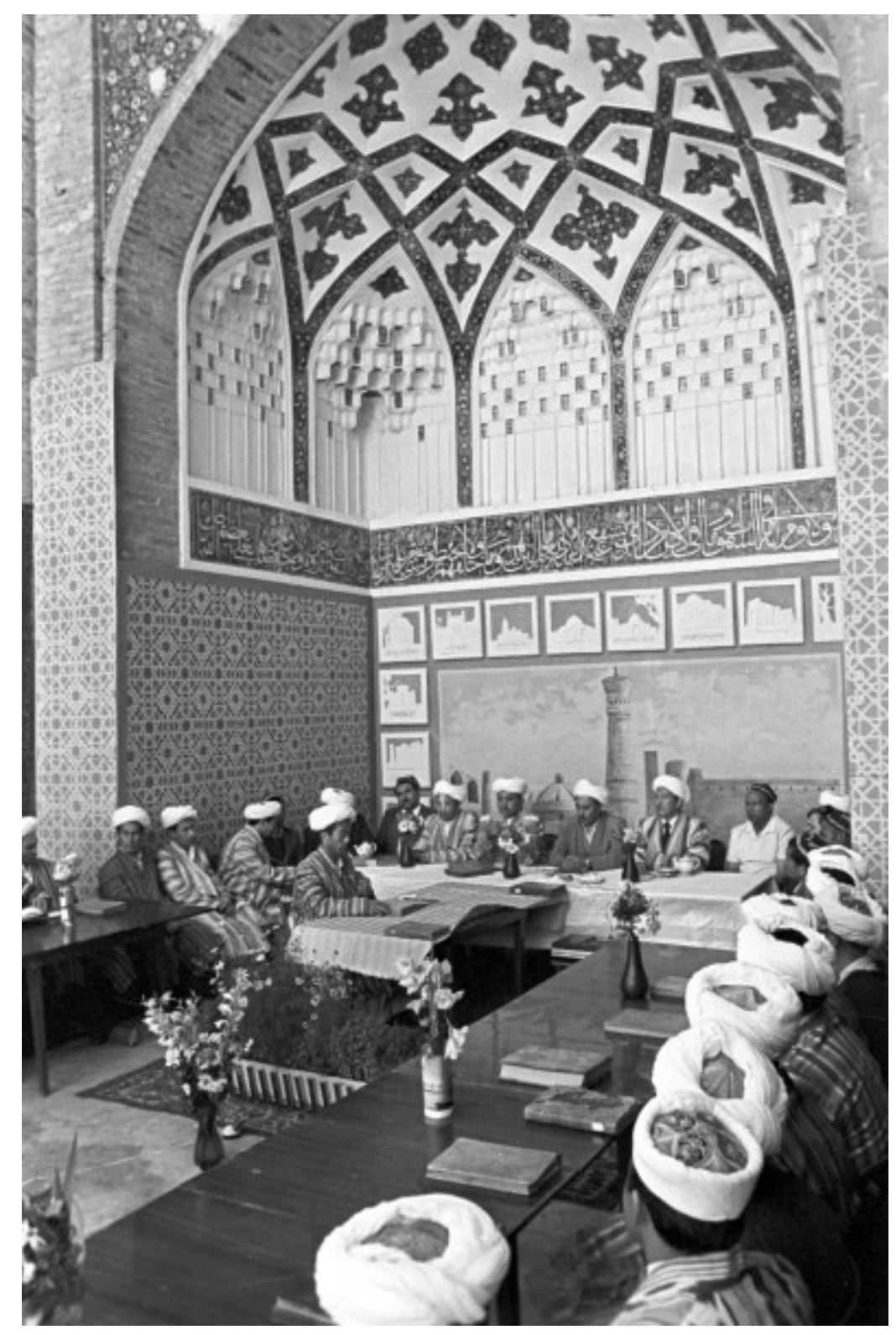

Picture 3. Graduation exam at Miri Arab Madrasa in Bukhara, $1979^{128}$

In October 1945, the Council of People's Commissars ordered the re-opening of two previously eminent Central Asian madrasas, Miri Arab in Bukhara and Barakkhan in

\footnotetext{
${ }^{128}$ A. Varfolomeev, RIA Novosti, http://visualrian.ru/hier_rubric/photo_historic/822751.html
} 
Tashkent. The madrasas had two tasks: 1) to prove that freedom of religion and religious education in the Muslim regions of the USSR actually existed; 2) to educate young Soviet Muslims who did not see contradictions between religion and socialism. ${ }^{129}$ The first task addressed the needs of the state to use religious actors in foreign affairs, while the second task aimed to regulate domestic uses of religion. These tasks were achieved by channeling faith through restrictive secular space, where the behavior of Muslim students was framed within the moral principles of a Soviet citizen. The second task opened a window to the foreign East, to engage with new, foreign developments in Islamic education, especially as Soviet madrasa students travelled and studied on statesupervised exchanges abroad. This chapter will focus on the education of an influential generation of Soviet ulama in Egypt's prestigious Al-Azhar University. Connections between domestic and international affairs also shaped the curriculum of education in Soviet madrasas. Increasingly secular subjects were incorporated into the curriculum, suggesting that graduates of Soviet madrasas were trained as well for bureaucratic positions and diplomacy.

This chapter will also examine the changes in curriculum between 1945 and 1980s, as the madrasas began teaching secular and religious subjects together. Traditional madrasas taught only religious classes. However, SADUM's official madrasas were not the first Muslim institutions incorporating secular subjects into religious education. Before the re-opening of Soviet official madrasas, the Jadids, a progressive Muslim intellectual movement in the early $20^{\text {th }}$ century, opened similar schools which combined secular and religious subjects. Therefore, the Jadid legacy

\footnotetext{
${ }^{129}$ Khalilova and Babajanov, "Soviet Ideology in the Madrasa", 34.
} 
needs to be taken into account in analyzing education in Soviet madrasas. Other religious institutions in the Middle East also experienced similar curricular changes.

This chapter will analyze the different actors and aspects that played significant roles in the religious education of Soviet madrasas. SADUM was not alone in designing the curriculum and managing the madrasas. According to Tasar, two other sources besides SADUM influenced madrasa education: The Soviet state and informal ulama. Tasar's approach characterizes the Soviet madrasa as an institution that benefited from its symbiotic connections with multiple layers of actors, including official and unofficial ulama. This chapter will further introduce relations with foreign and international actors as another formative connection in the Soviet madrasa network.

\section{Official Madrasas as an Institution to Discipline Soviet Muslim Citizens}

The format of Islamic education, in terms subjects and methods, after madrasas were officially re-opened after the war, resembled the style of traditional madrasas in Central Asia. Curriculum included the Arabic and Persian languages, kira'at (proper way of reciting the Quran), fiqh (Islamic jurisprudence), akida (dogma), tafsir (interpretation of the Quran), mantik (logic), and calligraphy. The teaching method was based primarily on reading and memorizing canonized religious texts and commentaries under the guidance of a teacher. SADUM and its re-opened madrasas may have been relatively more autonomous in designing their curriculum in the late 1940s. Initially, the party- 
state did not considerably interfere with the composition of subjects, teaching methods and attire of students at the Miri Arab madrasa. ${ }^{130}$

Later, the Republican Commissioner (Chairman) of CARC attempted to directly intervene in the composition of the madrasa program and other aspects of Islamic education. For example, in 1948, the Deputy Chairman of the Council, Iskandarov, after reviewing the list of religious subjects in the Miri Arab madrasa, sent a report to Moscow, which challenged the inclusion of a hadith course in the madrasa curriculum. CARC Chairman I.V. Polyansky's response (February 18, 1948) was remarkable:

The sayings and deeds of Muhammad comprise the bulk of Madrasa programs and therefore is not a new issue requiring consideration by the Council for Religious Cults. Based on this, the Council believes that you should not obstruct the inclusion of hadithology lectures in the course "The Sayings and the acts of Muhammad". ${ }^{131}$

This letter effectively granted SADUM autonomy in compiling the necessary courses of "religious subjects" in the madrasa and confirmed the previously adopted program of balancing disciplines classified as "secular" (e.g., Geography, History of the USSR, Social studies and Humanities) and "religious".

The autonomy of SADUM in compiling religious classes did not necessarily entail the complete freedom of Soviet madrasas from Soviet state intervention. The students of Soviet madrasas were expected, first of all, "to follow the moral principles of the Soviet citizen," as prescribed in the Code of Conduct of the Miri Arab Madrasa:

Madrasa students should always remember that they are considered students of the great Soviet state. Along with worship and the study of religion, it is

\footnotetext{
130 Khalilova and Babajanov, 41.

131 Khalilova and Babajanov, 43.
} 
necessary to follow the rules of morality inherent to the Soviet citizen, to uphold patriotic spirit, to respect the orders of the state, and to be hardworking, highly cultured and respectable people. During and after madrasa education, students should not be arrogant, should not indulge in fanaticism, and Sufism, should stay away from proscribed activities, and should have the behavior of a Soviet citizen. Students should pay great attention to the study of modern sciences and the foundations of Islam, especially the study of the Russian language. ${ }^{132}$

This prescription indicates the elements of Soviet Muslim identity that SADUM attempted to promote and Soviet madrasas to generate. The code of conduct defined the proper behaviour acceptable in Soviet madrasas. First of all, religion was filtered through the party-state's expectations for the behaviour of a Soviet citizen, which included commitment to Soviet moral principles alongside obeying the law. Second, it proscribed Sufism (considered by state as superstitious and mystical) and fanaticism (unbalanced enthusiasm towards Islamic topics). Third, it promoted the harmony of Soviet and Muslim identities, manifest in the Soviet Muslim patriot who was ready to fulfil the orders of the state and at the same time diligently follow the principles of their faith. Madrasa students had to be diligent, cultured, and able to speak Russian. The Soviet Madrasa students were expected to exemplify the compatibility of Islam and socialism.

There were similar expectations and limits on the behaviour of madrasa students sent abroad. For example, a 1955 order from the CARC to Muslim students sent to study at Al-Azhar University in Cairo is a good example:

When leaving for Egypt to receive a higher Muslim education at a university in Cairo, Muslim students should simultaneously remember their high rank_as a citizen of a Soviet country and the obligations that this title imposes on them, and in all their actions and statements abroad should consider the national interests

132 Khalilova and Babajanov, 49. 
of the homeland, not committing acts that could diminish their dignity as Soviet citizens.

Muslim students from the Soviet Union should strive to do everything possible to dispel the misconception of their co-religionists abroad about the state of Islam and the life of Muslims in the Soviet Union. Muslim students should tell students from other countries, in conversations with mudarris (university lecturers), clergymen and religious leaders, about the achievements of the Soviet people in the field of economics, culture and science, about the enormous changes that occurred in the life of Muslims in the Soviet Union, and the friendship of the peoples of the Soviet Union.

While living in Egypt, students from the Soviet Union should not make dubious acquaintances and visit various night entertainment places (restaurants, cabarets, bars, dance halls, etc.).

Muslim students from the Soviet Union will conduct such conversations with representatives of other countries as they deem appropriate and which do not contradict their beliefs as Muslims and citizens of the Soviet Union.

In all conversations with anyone, Muslim students from the Soviet Union are advocates for a policy of peace and better relations between countries.

Showing courtesy and respect for their local hosts, determined by the traditions of Muslims, students should not lose the dignity of a Soviet citizen. ${ }^{133}$

Similar to the madrasa code of conduct, this order reminds Muslim students to follow the Soviet moral principles, and to preserve the dignity of a Soviet citizen. It also obliges students to tell foreigners about economic and scientific achievements in the Soviet Union, intentionally omitting discussion of religious achievements. The focus on secular domains such as economy, culture, and science, despite the students' own religious educational background, limited the space for religion. Nonetheless, the order similarly emphasized the compatibility of Islam and socialism. The Soviet madrasas trained a generation of pragmatic Soviet Muslims who did not see any contradiction in combining the morality of the Soviet patriot-citizen and Muslim and the party-state was

\footnotetext{
133 Dmitriy Arapov, Islam i sovetskoe gosudarstvo (1944-1990). Sbornik dokumentov. Vypusk 3 (Moskva: Mardzhani, 2011), 116.
} 
eager to use foreign educational exchanges to showcase the successes of this Soviet Muslim generation.

The start of Khrushchev's anti-religious campaign in 1958 strained the conditions in which SADUM operated its madrasas. To the extent that madrasas operated during the height of the campaign, it was primarily due to Khrushchev's belief that SADUM and madrasa were most useful in international affairs. While state authorities closed down the Barakkhan madrasa in 1961, the Miri Arab madrasa remained open as the Soviet Union promoted to the Middle East the freedom of Soviet Muslim citizens to pursue religious education and displayed its own madrasa as a showcase to foreign guests.

Consequently, SADUM's international linkages increased during the Khrushchev era. Even under the anti-religious campaign, the Miri Arab madrasa expanded the number of countries where graduates could go for further studies, such as Syria and Morocco. SADUM's international contacts increased during these years as well, which also impacted religious education within the Soviet madrasas. During the visits of various international delegations, the staff of SADUM and the madrasa were partly autonomous, since they had to demonstrate the freedom of religion in the Soviet Union.

As discussed in the second chapter, the muftis and local imams over time "learned to extract their dividends from such international contacts, despite the weight of verbal instructions with restrictions." ${ }^{134}$ For instance, when SADUM officials asked for resources to renovate a mosque and build a new one, they usually formulated it around the idea of leaving a better impression on foreign guests. In a way, the attempts of

\footnotetext{
${ }^{134}$ Khalilova and Babajanov, "Soviet Ideology in the Madrasa", 34.
} 
Khrushchev and other allied anti-religious hard liners' to constrain SADUM for state use in international affairs actually benefited SADUM, by allowing it to determine and change the content of religious education in line with other Islamic institutions in the Muslim world. SADUM used this opportunity "to develop a pool of Islamic bureaucrats to advance its mission of institutional expansion in Central Asia; and, to embody a progressive Islam in harmony with Soviet society and, more generally, the modern world." ${ }^{35}$

Soviet Madrasas Follow Trends in the Middle East

SADUM followed the predominant trend among many religious organizations in the Middle Eest in radically changing the format of madrasa curriculum through exchanges with institutions like Al Azhar. ${ }^{136}$ The records of a July 24, 1957 meeting between CARC Deputy Chairman Prihodko and SADUM Chairman Z. Babakhanov in Moscow demonstrate how Soviet madrasas sought to follow trends in the Middle East:

[Babakhanov:] The religious schools existing in Tashkent and Bukhara are in dire need of textbooks. Old pre-revolutionary textbooks have become unusable, and new textbooks can be purchased only in the countries of the Muslim East. The number of students in the two madrasas is growing from year to year. The Spiritual Administration appealed to the Council for assistance in acquiring the necessary educational and religious literature from Egypt, but the resolution of this issue was delayed. Due to the fact that there is still a little time before the start of the school year, the Spiritual Administration has to appeal to the Council with a request to speed up the resolution of this issue. ${ }^{137}$

\footnotetext{
135 Tasar, “The Official Madrasas of Soviet Uzbekistan”, 280.

136 Zilola Khalilova, “Slushateli Medrese Sovetskogo Uzbekistana (1945-1991 Gg.): Sotsial'naya Zhizn' i

Povsednevnye Praktiki," Rossiya i Musul'manskiy Mir, no. 10 (304) (2017): 49-64.

137 Dmitriy Arapov, Islam i sovetskoe gosudarstvo (1944-1990). Sbornik dokumentov. Vypusk 3 (Moskva:

Mardzhani, 2011), 163.
} 
CARC Chairman A.A. Puzin acted upon Prihodko's promises of a speedy resolution of the textbook import issue to Babakhanov when, in February 1958, he addressed CPSU Central Committee Secretary N.A. Mukhitdinov with a request to allow SADUM to bring religious literature into the USSR from "Egypt, Syria, and other countries." Puzin's letter indicates that he had already secured approval for the request from Glavlit, the state censorship agency. Moreover, the title of this letter, "On the use of Muslim and other religious organizations of the USSR in order to strengthen Soviet influence in the countries of the East," demonstrates the state's primary attitude towards Soviet madrasas as a diplomatic asset in relations with the Islamic world. ${ }^{138}$

An official biography of SADUM Mufti Z.Babahanov, sent by Commissioner of the CRA under the Council of Ministers of the Uzbek SSR S. Shirinbayev to CRA Chairman A.A. Puzin in 1964, also shows how Soviet madrasas emulated Middle Eastern countries in their program:

His eminence [Z. Babakhanov] rendered great services in revising the program of study at the Miri Arab madrasa in Bukhara. At present, the program of study in the Miri Arab madrasa corresponds to the program of Al-Azhar University. He sent a group of graduates to Al-Azhar University, another group to the University of Damascus and a third to Karavinsky [Al-Qaray] University of Fez. ${ }^{139}$

These documents demonstrate that SADUM was following the curriculum of religious education in Middle Eastern countries and purchased textbooks from abroad. They also indicate that the initiative for changes in the curriculum came from SADUM, although they still had to inform and negotiate with the CARC. These examples explain

\footnotetext{
138 Dmitriy Arapov, Islam i sovetskoe gosudarstvo (1944-1990). Sbornik dokumentov. Vypusk 3 (Moskva: Mardzhani, 2011), 169.

139 Dmitriy Arapov, Islam i sovetskoe gosudarstvo (1944-1990). Sbornik dokumentov. Vypusk 3 (Moskva: Mardzhani, 2011), 239.
} 
how and why Soviet madrasas tried to combine religious and secular courses in their curriculum, and to what extent other state apparatuses like the CARC affected this process. As the letters show, SADUM had the initiative in designing the curriculum and following other religious institutions in the Middle East.

Babajanov, based on interviews with Soviet madrasa graduates who studied on exchanges abroad in the 60s, argues that the educational institutions of the Islamic world observed similar contemporary changes in the composition, combination, and teaching methods of "religious" and "secular" subjects, such as Egypt's famous and oldest university of Al-Azhar, which had faculties in medicine and engineering. Consequently, Babajanov claims that the changes in the religious education of Soviet madrasas "should be placed in the context of reforms of religious education in the Muslim world." ${ }^{140}$ Soviet madrasas, similar to Jadid schools, and following the trend in the Muslim world at the time, incorporated courses in humanities into their curriculum. Tasar argues that such changes in religious educational institutions resulted ultimately from colonial rule and transformation. The intrusion of modern states in Islamic education is another similarity among religious institutions in other Muslim countries. The following section will use the design of Miri Arab madrasa's curriculum and the memoirs of Umar Idrisov, a Miri Arab graduate, to explore the extent of SADUM's autonomy in managing its madrasas under the party-state.

${ }^{140}$ Khalilova and Babajanov, "Soviet Ideology in the Madrasa", 47. 
Curriculum Change in late 1960s

A 1967 inquiry into the Miri Arab madrasa within the Council for Religious Affairs revealed the following list of classes taught in the madrasa:

Religious:

1. Reading of the Quran

2. Interpretation of the Quran

3. Hadiths of the Prophet

Humanities:

1. Speaking Arabic language and literature

2. Grammar of the Arabic language

3. Russian

4. Arabic script calligraphy

5 . Economic geography of foreign countries

6. History of the USSR

7. Social studies

8. Physical culture ${ }^{141}$

The list indicates that by the 1967-68 schoolyear, secular classes constituted more than half of the curriculum, whereas previously until the mid-1950s they only comprised about one-third. ${ }^{142}$ During Khrushchev's leadership of state-directed antireligious campaigns, the CARC and local governments became more intrusive in education and religious affairs. In addition, madrasas followed the general restructuring of education in Soviet schools. Changes in patterns of subject classes, such as an increased focus on humanities, was a general trend in all Soviet schools. ${ }^{143}$ The second important reason for including secular subjects, could be the influence of former Jadidist reform projects among the official ulama of SADUM. Memoirs of Umar Idrisov, Soviet-

\footnotetext{
${ }^{141}$ Dmitriy Arapov, Islam i sovetskoe gosudarstvo (1944-1990). Sbornik dokumentov. Vypusk 3 (Moskva: Mardzhani, 2011), 251-253.

142 Khalilova and Babajanov, "Soviet Ideology in the Madrasa", 44.

143 Khalilova and Babajanov, 45.
} 
era graduate of Miri Arab and later Mufti of Kazan, who studied at Miri Arab Madrasa

during the Soviet era, also reveal important elements of the madrasa curriculum, including Jadidist influences:

Why did we all need to learn geography and the history of Uzbekistan? The Bukhara madrasa is a school of Jadidist direction, and such a combination of religious and secular knowledge is only beneficial. Even learning historical materialism in our years, I think it was right. Indeed, in the madrasa, students did not even know much about their own country, Uzbekistan. "Show the orange republic," their teacher asked, and by color they looked for something orange on the map.

About the history of the Soviet state, specifically the Uzbek SSR, lectures were given by Muhammad Sadyk, a teacher from a secular university. M. Sadyk, was a rare person who received an Islamic education in Libya, and therefore he introduced some elements of the Libyan school to Bukhara such as the necessity of studying the sunnah. ${ }^{144}$

In his memoirs Idrisov approves of the combination of religious and secular, including Marxist theory, subjects as a Jadidist approach to education. Notably, some of the teachers at Miri Arab also introduced new teaching methods learned abroad in other Islamic countries, demonstrating foreign influences on Soviet madrasa education.

Jadidism was a global intellectual movement which emerged in the late $19^{\text {th }}$ century, trying to modernize Muslim societies through educational and cultural activities such as establishing modern schools. Jadidis claimed that the cultural stagnation of Muslim societies was due to the stagnant educational system. ${ }^{145}$ Jadidis reconceptualized modern ideas about progress, education, enlightenment and tried to apply these notions in the Muslim worldview. Their main argument was that traditional Muslim thought was in a state of rigidity, unable to develop and overcome the

\footnotetext{
144 Idrisov, Bukharskie vospominaniya.

${ }^{145}$ Khalid, Islam after Communism; Khalid, The Politics of Muslim Cultural Reform.
} 
contemporary crisis of stagnation and domination by European empires. They argued that Muslims needed a religious and cultural reform of traditions otherwise unable to deal with the needs of the modern world. Therefore, in Central Asia members of Jadidi movement opposed to the elite class of traditional ulama, the political rulers of local khanates and the existing social structures of the time.

Jadidis introduced a new method of teaching and established new schools which combined religious and secular subjects. In the 1920s, three different types of schools functioned in the region: traditional madrasas, Jadidi new method schools and the Russian schools, each representing a competing imagination for the future of Central Asian communities in the region. Tension and conflict as well as negotiation and interaction characterized relations between these distinct movements until 1937 in the region. ${ }^{146}$ Jadidis were imagining a Muslim nation based on ethno-linguistic notions. They emphasized that people's relationship to Islam should be filtered through ethnic discourse. Soviets on the other hand envisioned a secular nationalist idea, where ethnic discourse merged with socialist discourse. Jadidis opposed religious fanaticism (which in their view entailed dominant traditions) and promoted such progressive ideas as the involvement of women in education and social work, the training of cadres for different secular jobs, language programs in schools, development of industry, trade and the banking system, and regulation of (religious) custom. ${ }^{147}$

\footnotetext{
${ }^{146}$ Ashirbek Muminov, Uygun Gafurov, and Rinat Shigabdinov, "Islamic Education in Soviet and Post-Soviet Uzbekistan," in Islamic Education in the Soviet Union and Its Successor States (Routledge, 2009), 233-89. ${ }^{147}$ Khalid, The Politics of Muslim Cultural Reform; Adeeb Khalid, Making Uzbekistan: Nation, Empire, and Revolution in the Early USSR (Cornell University Press, 2015); Adeeb Khalid, "Nationalizing the Revolution in Central Asia: The Transformation of Jadidism, 1917-1920," A State of Nations: Empire and Nation-Making in the Age of Lenin and Stalin, 2001, 145-62.
} 
In the late 1920s, Stalin sided with Russian educated socialist intellectuals in order to accomplish his Marxist visions for development, arresting, exiling, or, more often, executing many Jadidi scholars and traditional ulama. After the Great Terror, few of the ulama of the pre-Stalin era remained. The Great Terror years profoundly impacted religious education in the region, since traditional madrasas were closed and many ulama were killed or exiled. The lack of madrasas, maktabs and ulama created an absence of trained and qualified authorities who could interpret religious law and dogma in the region.

However, some members of Central Asia's religious scholarly community notably survived the Great Terror and would later involve themselves in projects of reinstitutionalizing Islam in the region after the Second World War under the direction of, and sometimes in spite of, the party-state. The ulama of the Ferghana and Tashkent regions learned how to cooperate and compromise with Soviets and fared the Great Terror era relatively better than others. ${ }^{148}$ Leading members of SADUM, such as the Babakhanov father-son duo, represented the generation of loyal Muslim scholars from the Tashkent region who survived the Great Terror. Idrisov's reference to Miri Arab madrasa as a "Jadidi school" suggests that Jadidi ideas also survived among the Central Asian ulama, despite the virtual death of the Jadidi movement under the Great Terror.

148 Babajanov, Muminov, and Kügelgen, Disputy musul'manskikh religioznykh avtoritetov, 17-18. 


\section{The Issue of Employment}

In addition to secular state control and the persistence of the Jadidi legacy, Soviet madrasas also included secular subjects out of consideration for the employment of graduates. Babajanov claims that the "employment" of madrasa graduates was very important to the SADUM administration. ${ }^{149}$ For instance, Ismail Sattiev, director of the Miri Arab madrasa, took the initiative to strengthen the teaching of subjects that could be useful for graduates in work for not only SADUM and local mosques but also secular state structures. Thus, in addition to religious classes and Arabic language, the Miri Arab madrasa curriculum also included Asian-African History and Political Economy, English and physical education. The leadership of SADUM did not shy from strengthening secular (essentially Soviet) subjects, citing the desire to prepare graduates for life in "Soviet society," who could also connect Soviet Muslims with foreign Muslims. From this perspective, SADUM's initiative to adapt to existing realities in the Soviet Union drove the inclusion of secular subjects in the madrasa (arguably as much as the intrusions of secular state structures). ${ }^{150}$

Madrasas tried to raise cadres who could be useful for the Soviet bureaucracy in domestic and international affairs. The following letter sent by the head of education section of the Miri Arab madrasa, S. Ziyautdinov, to the CARC Chairman, A. Puzin, included the list of Miri Arab madrasa graduates in 1964. In addition to a short biography, madrasa administrators also recommended a career path for each graduate.

\footnotetext{
${ }^{149}$ Khalilova and Babajanov, "Soviet Ideology in the Madrasa", 48.

150 Khalilova and Babajanov, 48.
} 
SADUM compiled the list, taking into account graduates' relevant work in religious and other organizations.

1. SAIFULA ADYLOV, born 1933, Tajik from Isfara, Tajik SSR. Entered madrasa in 1956, graduated in 1964. Exhibited good behavior and no ideological deviations. Based on educational background and religious knowledge, can work in a mosque as Imam-Khatib.

2. RAHIMJAN MUSTAFAKULOV, born 1936, Uzbek from Kuk-Tash village, Leninsky region in Tajik SSR. Entered madrasa in 1956, graduated in 1964. Disciplined, ideologically stable, [but] sometimes hot-tempered. Can work as SADUM representative or in a mosque.

3. MANAP SHALBAEV, born 1928, Kazakh from Arys, Kazakh SSR. Entered madrasa in 1956. Disciplined, polite in speech, ideologically stable. Can work as Imam-Khatib.

4. AHMADKHAN AZIZKHODJAEV, born 1930, Uzbek from Namangan, Uzbek SSR. Entered madrasa in 1956, graduated in 1964. According to the level of knowledge and behavior, can work as imam.

5. MAKHAMADALINKHAN ISMAILOV, born 1930, Uzbek from Namangan, Uzbek SSR. Entered madrasa in 1956, graduated in 1964. Disciplined, [but] worked in the trading system during holidays and will probably continue to work in trading system.

6. ABDUKADYR KATTABEKOV, born 1932, Uzbek from Marhasht district, Andijan region, Uzbek SSR. Entered madrasa in 1956, graduated in 1964. Disciplined, possessed good knowledge, comfortable in public settings, and served as chairman of student committee. With availability of opportunities, can be sent to study abroad.

7. ATAKUL MAVLANKULOV, born 1938, Uzbek from Kokand, Uzbek SSR. Entered madrasa in 1956. Disciplined, performed well in studies, and by nature does not fit the spiritual service. If possible, can be sent to study abroad.

8. JALALITDIN TASHKHODJAEV, born 1937, Uzbek from Osh oblast, Kyrgyz SSR. Entered madrasa in 1956. Disciplined and by nature suitable to work as imam. ${ }^{151}$

${ }^{151}$ Dmitriy Arapov, Islam i sovetskoe gosudarstvo (1944-1990). Sbornik dokumentov. Vypusk 3 (Moskva:

Mardzhani, 2011), 241. 
In the list, madrasa administrators recommended two of the seven Miri Arab graduates as candidates for studying abroad. Students who perform well in studies were considered to send abroad, in particular, authorities may have considered Mavlankulov, listed seventh in the letter, who was seen as unfit for spiritual service but a good candidate to send abroad, for a position in state bureaucracy or even intelligence services. Notably, focus on (disciplined) behavior of students in the list reminds the earlier mentioned Miri Arab madrasa's code of conduct, which also underlined "the behavior of a Soviet citizen." The list illustrates that madrasa students were not only trained for religious services, but also for other more practical and bureaucratic jobs. Some of them worked as translators for the CARC and SADUM, while others went on to work for the Institute of Oriental Studies in Tashkent. Some of them were sent abroad for further studies. Therefore, the training included an extensive course on learning Russian and Arabic to prepare candidates for bureaucratic services and foreign research.

How influential was Miri Arab madrasa in Central Asia? In the 1966/1967 academic year, around fifty students were studying in the Miri-Arab madrasa. There were five teachers for religious classes and three teachers for secular subjects, and a degree lasted for 9 years. Each year the madrasa graduated between ten and twenty students. These numbers are insignificant compared to the millions of Muslims in Central Asia, especially as religious activities and the number of mosques increased by the late 1960s and 1970s. The Miri Arab madrasa could not fulfill the need for education. In addition, the proportion of religious classes in the Miri Arab madrasa was declining and constituted only one-third of the curriculum by 1967 . Only three students 
were studying abroad, and this number did not change throughout the late 60 s and early 70 s.

During Brezhnev's leadership, religious institutions and actors had a more stable environment, in order to fill the gaps in the religious educational front. An Islamic Institute named after Imam Al Bukhari was opened in Tashkent in 1971. The Islamic Institute's diploma of "higher special religious education" equaled a bachelor's degree in the Soviet education system. The curriculum followed that of the Miri Arab madrasa but included a teaching practicum. Umar Idrisov remembers that the madrasa teachers did not have much practical experience, and most of them in the 1970s and 1980s were graduates of these same madrasas themselves, whose practical experience was limited. Teachers at the Islamic Institute, on the other hand, were mostly foreign educated and better qualified to teach. The new institute aimed to train better qualified loyal cadres.

\section{Relationship between Official and Unofficial Madrasas}

Soviet religious education had two levels; The first one, was an underground network of unofficial madrasas, which the authorities tried to suppress through the power of state structures and public organizations. The second level was official madrasas with smaller numbers of students, who passed numerous difficult stages of the selection process by SADUM, CRA, party organs, SSR governments, and state security agencies. Only a handful of graduates from these educational institutions could 
go to foreign Islamic universities. ${ }^{152}$ Ultimately, many students chose to study at the official madrasas to formalize the religious education they first received privately in clandestine madrasa (hujras). ${ }^{153}$

Hujras were small clandestine and informal madrasas, which held classes early in the morning or at night for small groups of up to six or seven students. Subjects changed according to the teacher, but most of the hujras tried to continue traditional form of education of the pre-Soviet madrasas. Some hujras were run by "Wahabis", like Abduvali Qori and Rahmatullo Alloma. Other hujras taught more local-traditional, Hanafite jurisprudence sometimes excluding local Sufi traditions (such as Salim Hojji in Bekabad) or even including aspects of Sufism like poetry (e.g., Mahdum Bobo in Samarqand). ${ }^{154}$ The informal educational scene in Central Asia was more colorful and vibrant than the official madrasas.

Hujras, previously only popular in Ferghana and Tashkent regions, became more popular in other parts of Central Asia, especially during the 1970s and 1980s. The sizes of classes increased to up to twenty students, and some teachers held classes in unofficial mosques. Informal ulama and their clandestine madrasas played an important role in traditionalizing Islamic education in the region. Hujras typically practiced a more traditional style of teaching, mostly focused on teaching tajvid (recitation of Quran) and

\footnotetext{
152 Vyacheslav A. Akhmadullin, “Osobennosti sovetskoy sistemy dvukhurovnevoy podgotovki islamskikh kadrov: opyt i uroki," Islam v sovremennom mire 11, no. 2 (2015): 153-64.

153 Ibid.

${ }^{154}$ Martha Brill Olcott and Diora Ziyaeva, "Islam in Uzbekistan: Religious Education and State Ideology," Russia and Eurasia Program (Washington: Carnegie Endowment for International Peace, September 2008), https://carnegieendowment.org/2008/09/10/islam-in-uzbekistan-religious-education-and-state-ideology-pub21980; Bakhtiyar M. Babajanov, "Khudzhra," in Islam na territorii byvshey Rossiyskoy imperii: entsiklopedicheskiy slovar'. Tom I, ed. Stanislav M. Prozorov (Moskva: Vostochnaya literatura, 2006).
} 
Arabic grammar. Teachers (domulla) with higher experience and prestige could grant an ijoza (license) to their students, which permitted them to practice or interpret fiqh (Islamic jurisprudence) in specific domains. ${ }^{155}$

In contrast to official madrasas, which included secular subjects that comprised more than half of the curriculum, education in hujras focused only on religious classes. Each hujra had its own specific set of courses and a targeted curriculum. For instance, Domullo Hindustani, who started his own hujra in the 1950s in Dushanbe, Tajikistan mainly took students with prior education and comprehensively taught higher level subjects.

Education in a hujra was not seen as a substitute for SADUM's madrasas, but rather an avenue for certain skills and knowledge that supplemented the official education. ${ }^{156}$ The relationship between official and unofficial madrasas resembled traditional religious education in the region, where students wandered among different madrasas to learn specific skills and acquire licenses from certain ulama. In the Sovietera, students could continue their education at some hujra even after graduating from official madrasas. One example is a jurisconsult who attended the hujra of Okhunjon Haydarkhon, in the Batken region, Kyrgyzstan, after graduating from the Miri Arab madrasa, and later completed his studies under Domullo Hindustoni, in Dushanbe. ${ }^{157}$ Another example is Baba Muhammad, who ran a hujra in Surkhandarya, Uzbekistan with a curriculum specifically designed to teach fiqh. While some Baba Muhammad's

\footnotetext{
155 Babajanov, “Khudzhra”, 428-429.

156 Tasar, "The Official Madrasas of Soviet Uzbekistan"

${ }^{157}$ Tasar, 294.
} 
students who wished to pursue more advanced studies went on to study with Hindustani, Hindustani also sent some students to study fiqh with Baba Muhammad. ${ }^{158}$ These exchanges and the routes of students among different madrasas and hujras ran by official and unofficial ulama shows the complex nature of educational patterns in Soviet Central Asia.

Official and unofficial Islamic education in Central Asia intersected and, indeed, enjoyed a generally symbiotic relationship. For example, Ismail Sattiev, director of the Miri Arab madrasa, ran his own hujra. Abdurashid Domulla, senior representative of SADUM in Tajikistan in 1950s, also opened a hujra in Dushanbe in 1956 and had a close relationship with Domulla Hindustani, one of the most influential figures among informal ulama. ${ }^{159}$

However, official and unofficial ulama sometimes did conflict over differing Islamic education. SADUM Mufti Z. Babakhanov, known to hold a strong reformist position, visibly transferred and removed other officials with whom he disagreed. One example is Nodirhon Domulla, who ran a hujra in Tashkent until his death in 1976. Starting from 1943, he worked in SADUM as head of the fatwa department and was later removed from this position to become a librarian during Z. Babakhanov's leadership because of disagreements over the content of the fatwas. ${ }^{160}$ Similarly, Abdurashid Domullo, who also ran his own hujra and was senior representative of SADUM in Tajikistan, was removed from his position due to disagreements with $Z$.

\footnotetext{
158 Olcott and Ziyaeva, "Islam in Uzbekistan", 7.

159 Olcott and Ziyaeva, "Islam in Uzbekistan", 7-11.

160 Olcott and Ziyaeva, "Islam in Uzbekistan", 7.
} 
Babakhanov, and re-appointed imam of a small mosque in Dushanbe. These examples show that divisions among religious scholars in Soviet Central Asia was more over distinct dogmatic and legal interpretations of Islam rather than a state-imposed distinction of official and unofficial Islam. The fourth chapter will discuss the content of these divisions and disputes over the interpretations of Islam.

Official madrasas and the Islamic Institute in Tashkent continued their work until the collapse of the Soviet Union. In the 1980s, around fifty students attended official madrasas, with twenty more (officially) studying abroad. In the Miri Arab madrasa, the total number of applications for admission from 1975 to 1980 was three hundred, for twelve to fifteen places. In the 1980-1981 academic year, there were 116 applications for twelve places in Miri Arab madrasa. The total number of Miri Arab graduates from 1951 to 1980 was $147 .{ }^{161}$ These numbers indicate that the scope and impact of official madrasa expanded by the late 1970s, and the demand to study at the madrasa was also increasing. This shift in public sentiment may have been in accordance with religious revival in other Muslim countries, but the Soviet population was also increasingly getting disillusioned with socialism. ${ }^{162}$

In order to address these changes, madrasa administration oversaw a review of the madrasa curriculum in the early 1980s, remarking that "it does not meet the requirements of the time" and stressing that "changes will contribute to raising the level of religious knowledge of students." ${ }^{163}$ While some of the "secular disciplines" were still

\footnotetext{
161 Khalilova and Babajanov, "Soviet Ideology in the Madrasa", 42.

162 Kotkin argues that towards 1970s, and 80s Soviet citizens became increasingly unsatisfied with the Soviet economy. Stephen Kotkin, Armageddon Averted: The Soviet Collapse, 1970-2000 (Oxford University Press, 2008). 163 Khalilova and Babajanov, "Soviet Ideology in the Madrasa", 49.
} 
preserved, the Miri Arab madrasa and the Islamic Institute expanded the amount of religious subjects in their curricula. ${ }^{164}$

Hujras became increasingly more popular under the relative freedom of the 1980s as well, with the number and sizes of hujras increasing and becoming more widespread across Central Asia. The teachers in these hujras were mainly recruited from hujra graduates who received a traditional and conservative religious education in in hujras. The quality of education in the hujras sometimes suffered from the shortage of textbooks, and experienced teachers, the hasty preparations for opening new schools, and elementary courses in religious knowledge and ritual skills which neglected secular subjects. Nonetheless, since these new "old-style" madrasas became symbols of a religious revival in Central Asia, the patterns of religious revival were also mostly traditional and conservative. ${ }^{165}$

\section{Conclusion}

The Soviet madrasas, under the direction of SADUM and the CARC, formed a mixed identity among new generations of educated Muslims, in which self-perception as a Soviet citizen was compatible with being Muslim. Madrasas designed a specific curriculum combining religious and secular subjects which prepared the students to serve the state in different bureaucratic positions. The curriculum also clearly shows that it imposed Soviet ideology. The following lines from the memoirs of Umar Idrisov,

\footnotetext{
164 Khalilova and Babajanov, 46.

165 Khalilova and Babajanov, 49.
} 
about his years in the Miri Arab madrasa highlight importantly that the madrasa students were under the strict control of the CARC and CPSU:

...we received all information about events both in the USSR and from abroad only from official sources. It seemed to us, and we ourselves sacredly believed in this, that the Soviet Union is fulfilling its international duty... The Commissioners for Religious Affairs conducted conversations with us once a month, especially somehow without giving these meetings a formal, specific name... they simply gathered, talked ... Our teachers also fully accepted the official point of view on the protection of socialism and criticized capitalism.

In recent years, the term "Islamism" was invented as the name of a political party or a movement based on Islam. Was there such an "Islamism" in our BukharaTashkent years? Nothing of the kind - we were under the strict guidance of the ruling CPSU...It cannot be said that we were completely limited, but in this way, we avoided many problems and there were no Muslim dissidents among us, like the Islamists. I repeat - we were clearly and strictly told: ... "here are the rules, follow them, and there will be no problems!"166

Although the Soviet party state used its capacities to control the religious education in the madrasas, the staff of SADUM and the madrasas could still show initiative in their activities, such as in partly designing the curriculum and methods of teaching. They purchased books from abroad, and selected students to send abroad, students who later returned to teach and bring new methods and ideas from abroad. Unofficial ulama working in informal networks outside of the state also influenced the Soviet madrasas. Since official madrasas could provide official diplomas, hujra students could legalize their informal education through attending official madrasas. Teachers in the official madrasas and members of SADUM ran their own hujras, which shows that the formal and informal networks intertwined in various ways contributing to the official religious education system.

${ }^{166}$ Idrisov, Bukharskie vospominaniya. 


\section{Chapter 4: Debates of Reform}

The previous chapters addressed the institutionalization of Islam in Soviet Central Asia, the role of SADUM in international relations and the nature of Islamic education in Soviet madrasas. The main themes centered on the relationship between different actors such as SADUM, the state, and the official and unofficial ulama in Central Asia. This chapter will discuss the debates (concerning religious dogma) among official and unofficial ulama in Soviet Central Asia and explores the position of SADUM in these debates. The chapter will also explore the effect of SADUM's anti-innovation struggle in Islamic discourse during Soviet era. Exploring different visions of Islam and SADUM's position in debates among Muslim scholars will provide a better understanding of the influences over Soviet Islam in Central Asia.

Four different actors influenced Soviet Islam: the state, SADUM, the unofficial ulama, and the foreign ulama. ${ }^{167}$ In the interaction between these actors, three different views towards the meaning and nature of Islam emerged in Soviet Central Asia: traditionalist, reformist, and centrist. ${ }^{168}$ The traditionalist line of Islam in Central Asia upheld the canonized religious texts - the Quran and hadith - and various commentaries on these texts as the core of religious tradition. It also accepted (conservative) local custom as part of religion. However, it was strictly conservative in terms of accepting new changes. Reformists, on the other hand, emphasized the Quran and hadith as the original sources of religion and criticized local customs in the region. Centrists held

\footnotetext{
167 Tasar, "The Official Madrasas of Soviet Uzbekistan”, 266.

168 Babajanov, Muminov, and Kügelgen, Disputy musul'manskikh religioznykh avtoritetov, 30.
} 
syncretic views about Islam, in which different views and interpretations, including reformist views, co-existed.

Tasar's approach gives a more nuanced analysis, which positions SADUM's vision of Islam in a reformist line that combined Jadidism, Socialism and Salafism (reformism that opposed local customs). Based on Babajanov and Tasar's approach, this chapter will argue that the position of SADUM generally belonged to the reformist tendency, shifting from "Salafist reformism" under Ziyauddin Babakhanov (1957-1982) to centrism during the 1980s. This shift in position also coincided with the international context of Saudi Wahabi scholars' growing global influence. It was also a response to foreign "political Islamism" (interpretation of Islam as a political identity seeking to transform society based on Islamic principles $\left.{ }^{169}\right)$. In addition, the lack of experts opened a generational gap between young ulama educated in the Soviet official and unofficial madrasas who became reformist, and the older generation of ulama who were conservative. Although SADUM tried to play the centrist role in these schisms, reformists gained greater influence over its work, paradoxically incorporating radical anti-Soviet discourses into Soviet Islam.

Connections among old traditionalists and young reformists-who were mostly educated by the old traditionalist generation- demonstrated how the official and unofficial realms of Central Asian Islam were interconnected in complex ways, with schisms centering on issues of religious debate rather than a simple, state-sanctioned official versus unofficial divide. The debate among the local official and unofficial ulama

${ }^{169}$ Esposito, Political Islam: Revolution, Radicalism, or Reform? 
around different religious topics also demonstrated the local ulama's agency in shaping Islamic discourse during the Soviet era. The official and unofficial ulama had to navigate between different visions of Islam such as traditional Hanafi (Islamic school of jurisprudence with a more liberal interpretation) and "Salafist" interpretations (opposing all schools of jurisprudence, including Hanafi). ${ }^{170}$ Even under the authoritarian Soviet regime, different kinds of Islamic movements with different religious interpretations engaged in debate and polemics over their vision of Islam: Some of them were more moderate, while others were relatively more spiritual and ascetic (such as Sufi Naqshbandi orders), or radical movements (e.g., Wahabis).

SADUM was not totally independent, and, as discussed in the first chapter, was under the constant control of CARC, local government and other state agencies like the KGB. Yet, while Soviet state structures implemented an anti-religious policy to Sovietize its Muslim citizens, it also had to negotiate with local traditions and actors, forcing them to reshape what it meant to be "Soviet" and "Muslim". It was a complex task which demanded the involvement of local ulama. This process of negotiation involved convergence and confrontation between the goals of the Soviet state and the goals of official Muslim scholars in SADUM and other local unofficial ulama.

While the Soviet state sought "to transform SADUM into an organization engaging in activities that exclusively served the Party-state's policy objectives," ${ }^{171}$ the SADUM muftiate could voice its own interests within the restrictive limits that authorities prescribed. The CARC obliged SADUM to strictly follow its orders. However, sometimes

\footnotetext{
170 Peyrouse, "The Rise of Political Islam in Soviet Central Asia."

171 Tasar, "Soviet and Muslim", 291.
} 
SADUM displayed initiative in seeking to coordinate its actions with the requirements of the Committee. Below, for example, is the text of one such letter dated November 3 , 1960 and addressed from SADUM Deputy Chairman Sattiyev to the Commissioner of the CRA at the Council of Ministers of the Uzbek SSR, S. Shirinbaev:

[SADUM] issued prohibitive fatwas against superstitious rites, including the celebration of the Mawlid (the birthday of the Prophet). Considering the urgency of clarifying such issues among believers, we compiled a letter to the imam-khatibs and members of the Mutavalliyat (the board of trustees) of the mosques "About the order of the celebration of the birthday of the prophet - Mawlid." Please provide your opinion on its content. ${ }^{172}$

SADUM used Khrushchev's anti-religious policies to support the project of purifying Muslims' lives from, in their view, non-Islamic elements. It translated Khrushchev's anti-religious policy among local communities in Central Asia not as a struggle against religion, but rather as a struggle against unregistered mollas and religious innovations (bid'at). ${ }^{173}$ Ziyauddin Babakhanov used the idea of an antiinnovation campaign as a mechanism to gain more power and legitimacy in religious life. ${ }^{174}$ The interplay between a state-directed suppression and a locally-directed struggle against unregistered mollas and mosques opened new opportunities for SADUM to maneuver against its opponents, mainly conservative ulama.

\section{Z. Babakhanov and the Reformist Line}

The initiative to reform Islam and remove innovations (bid' at) originated in two main ways: firstly, pressure on SADUM from the regime to help the state in its struggle

\footnotetext{
172 Babajanov, "O fetvakh SADUM protiv 'neislamskikh obychaev'”, 1.

173 Tasar, "Soviet and Muslim", 538.

174 Tasar, 178.
} 
against specific religious practices deemed ideologically "unsuitable"; second, Z. Babakhanov's own enthusiasm about shaping rituals in accordance with "true" Islam. ${ }^{175}$ Here, true Islam was the purely textual understanding of Islam based on the Quran and hadith, purified from local customs and traditions. SADUM under the leadership of $Z$. Babakhanov attempted to reform Islam and make it compatible with the Soviet modernization project. ${ }^{176}$ Individual personalities like mufti Z. Babakhanov who managed SADUM from 1957 to 1982, and Deputy Chairman of SADUM I. Sattiyev played an important role in organizing religious exchanges and implementing policies.

Tasar argues that the charismatic authority of locally respected and revered religious figures played an important role in mobilizing Muslims and their communities in Soviet-era programs for social change. Accordingly, he attributes the strength of SADUM's institution-building agenda in consolidating authority over Soviet Central Asia's religious life to the influence and zeal of Z. Babakhanov in particular. SADUM's attempt to reform religious life was not merely due to external pressure from the partystate apparatus, as Z. Babakhanov directed its resources to combat disapproved traditional customs and the unregistered, informal mollas who practiced them. ${ }^{177}$

Ziyauddin Babakhanov (1908-1982) was born in Tashkent to a family of the famous Islamic religious leader Eshon Babakhanov. From an early age, he attended the lectures of his father and studied the Quran. In 1920s Z. Babakhanov studied tafsir and hadith in the Kukeldash madrasa. He also went to the Barakhan madrasa, where he

\footnotetext{
175 Khalid, Islam after Communism, 111.

176 Tasar, "Soviet and Muslim", 175.

177 Tasar, 178.
} 
learned additional religious lessons. In 1947, Z. Babakhanov, then executive secretary of SADUM and Qazi of Uzbekistan SSR, left for Egypt to study at the prestigious AlAzhar University. During his studies he established international contacts between SADUM and the Islamic world. After returning to the USSR in 1948, he was elected deputy chairman of the SADUM at the second kurultai of Muslims of Central Asia. At the third such kurultai held in June 1957, Z. Babakhanov was elected new chairman of SADUM and the mufti of the five Central Asian republics. Following the path outlined by the Al-Sahih Al-Bukhari, considered the most authentic Hadith compilation in the Islamic canonical tradition, he sought to strengthen the foundations of traditional Islam, leading an implacable struggle to purify it from various customs and rituals recognized as nonIslamic in the hadith tradition. ${ }^{178}$

Shami Domulla influenced Z. Babakhanov's Islamic views and his adherence to the teachings of Imam Al-Bukhari and his compilation of authentic hadith. Shami Domulla (1867-1932), was an important figure who significantly influenced the formation of Soviet Islamic discourse. S. Domulla received his education at Al Azhar University, but later emigrated to Central Asia from Arabic provinces of the Ottoman Empire where he was accused of being Wahhabist because of his reformist ideas. After wandering for several years in India and Iran, he moved to East Turkestan where he preached Salafi Islam. While in East Turkestan he started to collaborate with the Russian Embassy, and in 1919 moved to Tashkent. He died in 1932 in exile in Khiva. Bolshevik authorities originally believed Shami Domulla's ideas useful because of his harsh criticism against local custom, the traditional ulama, and other existing social structures, as well as his

\footnotetext{
178 Usmankhodzhaev, Zhizn' muftiev Babakhanovykh.
} 
anti-imperialist position. He believed the traditional heritage of medieval ulama was unnecessary, and that Muslim scholars should directly go to the original sources of Islam, the Quran and hadiths. Among the hadiths, Shami Domulla especially embraced Al-Sahih Al-Bukhari.

Shami Domulla and his disciples like Ziyauddin Babakhanov believed that they needed to use the methods of Bukhari to purify Islam from non-Islamic elements. The request of SADUM under Z. Babakhanov in 1972 to assume control over the mausoleum of Bukhari (discussed in Chapter 2), and its later organization of an international conference in 1974 of Bukhari's thought and legacy, demonstrated the importance of Bukhari to the SADUM leadership and symbolized the revival of Bukhari's methodology in Central Asian Islam. Previously, traditional ulama neglected Al Bukhari's mausoleum and methodology. Hadith were a powerful tool not only for religious scholars, but also for political authorities to legitimize their own position and to delegitimize their opponents. ${ }^{179}$ Likewise, Z. Babakhanov's revival of Al-Bukhari's thought in SADUM's Islamic discourse targeted the traditional ulama and (unorthodox) custom, now considered "unofficial" and underground in the Soviet political context. Babakhanov articulated this reformist discourse with official sanction through SADUM's fatwas.

\section{Examples of Fatwas Issued by Mufti Z. Babakhanov ${ }^{180}$}

\footnotetext{
${ }^{179}$ Babajanov, Muminov, and Kügelgen, Disputy musul'manskikh religioznykh avtoritetov, 13.

180 The exact date of the publication of these fatwas is unclear in Russian-language reprints. However, based on other sources like Babajanov and Olcott, it can be assumed that these fatwas were issued in 1952 or 1957.

Babajanov, "O fetvakh SADUM protiv 'neislamskikh obychaev'”; Olcott, "Roots of Radical Islam in Central Asia."
} 
Z. Babakhanov's fatwas illustrate a combination of Socialist, Jadidist and Salafist criticisms of local customs and practices. These fatwas exemplify Z. Babakhanov's voice and position on debates among ulama in Central Asia during the Soviet era.

Starting from the mid-1940s, SADUM issued a series of fatwas which had to be read aloud during Friday prayers in local mosques. According to Babajanov and Olcott, these fatwas were issued in response to the Soviet party-state and the CARC's demand to combat harmful remnants of the past. ${ }^{181}$ Some of the fatwas issued in 1952 , included topics like murids and ishans (Sufi and other local religious lineages), ziyarat (pilgrimage to the graves of the "saints"), khatm-i Kuran (collective readings of the Quran in private homes on religious holidays), and ceremonies and rituals associated with weddings and the commemoration of the dead. ${ }^{182}$ Most of these traditions had a social and sometimes political dimension. Especially murids and ishans were probably targeted because of their network of influence, as these traditions created their own social hierarchical structures, with key influencers (i.e. ishans). Ishanism was inherited through family lineages, while muridism was a form of spiritual commitment to a specific person (saint) with extraordinary and mystical skills.

Another fatwa issued in 1957 about commemorating the dead describes it as "one of the common types of wastefulness of Muslims in Central Asia", "continu[ing] in the house of the deceased seven, twenty and forty days after his death, as well as on the days of religious holidays of sacrifice and Ramadan." After a few references to

\footnotetext{
${ }^{181}$ Babajanov, "O fetvakh SADUM protiv 'neislamskikh obychaev"”, 1; Olcott, "Roots of Radical Islam in Central Asia", 6.

${ }^{182}$ Babajanov, "O fetvakh SADUM protiv 'neislamskikh obychaev"”, 3.
} 
hadiths and verses from the Quran, the fatwa claims that these kinds of behaviour "are superstitions, which, unfortunately, many Muslims still adhere to." According to the fatwa, "Muslims of many countries, guided by the teachings of the Prophet, have long been freed from such heresies", and that "such a ridiculous rite has nothing to do with Islam, since neither the Quran nor the Hadith of the Prophet has ever mentioned the rite itself, nor the calls for its commission." ${ }^{183}$ One of the important aspects in this fatwa is the emphasis given to the hadith, in criticizing local tradition and the international perspective (phrased "Muslims of many countries"). This method shows a call to return to the (original) textual practice of Islam, rather than to traditional practices dominant before the Soviet era in the region.

Another fatwa first issued in 1952 and later reissued several times because Central Asian Muslims continued to practice this custom, addressed visiting graves and making pilgrimage to shrines, typically one of the most controversial cases among ulama (across Islamic world). The Salafists criticized this custom very harshly and considered it a major sin, even equivalent to polytheism. As usual, the fatwa cited several hadith to demonstrate how local custom contradicted the appropriate way of visiting cemeteries and thus was prohibited under sharia. The fatwa concluded that "asking for help or support from a dead person in a grave does not correspond to the spirit of Islam and means polytheism, which is forbidden and unacceptable for a Muslim." 184 The fatwa, based on hadiths and verses from the Quran, resembled Wahabi criticism of the same custom.

\footnotetext{
${ }^{183}$ Usmankhodzhaev, Zhizn' muftiev Babakhanovykh. 184 Ibid.
} 
Apart from "religious purification", an additional concern among SADUM was illegal economic activity and personal profiteering through these customs, as people were "offer[ed] sacrifices to mazars, or so-called sacred places...bringing... gifts such as a multitude of sheep, goats, and also money."185 The fatwa considered such gift giving and especially personal enrichment at holy places as a grave sin, again equal to polytheism. In line with the Salafist criticism of this traditional practice, the fatwa also contained another dimension of concern over (impermissible) wealth and enrichment that paralleled the Soviet struggle against informal economic activities in local areas.

Another common theme in the fatwas concerned healers and fortune-tellers. Before the advent of modern medicine and doctors in Central Asia, people visited local healers, or tabip. Since the first (modern) doctors in Central Asia were usually nonMuslim, local Muslims, especially in rural areas, continued even into the Soviet period to see tabips instead of doctors. SADUM's relevant fatwa in response, first issued by $Z$. Babakhanov in 1952, then again in 1958 and 1964, called Muslims to see medical doctors instead of traditional healers.

The fact is that nowhere in the sharia is it mentioned that the doctor treating the patient must necessarily be a Muslim. The proof is a reliable story, mentioned in the books of hadith...186

After citing several hadiths, the fatwa mentioned developments in modern medicine and sciences,

Thanks to a number of great discoveries, the rapid development of medicine led to a marked decrease in mortality among people... We have,

\footnotetext{
185 Ibid.
}

186 Ibid. 
for example, eradicated eternal enemies of man such as typhus, plague, malaria and other serious epidemic diseases. ${ }^{187}$

After celebrating the positive developments in medicine and suggesting proper ways of treatment, the fatwa then mentions the bad habits and customs in Central Asian societies,

Unfortunately, nowadays, when progress has reached such heights, among some believers there are people so ignorant that instead of qualified doctors they prefer illiterate imaginary healers, fortune-tellers, spellcasters; that is, those who spread heresy, prejudices, and superstition strongly condemned by sharia. There are those Muslims who seek healing in the so-called sacred places. At the same time, they believe that they are following the very dogmas of Islam, not knowing, however, that their behavior is contrary to the commandments of the Prophet Muhammad... 188

In accordance with the Soviet ideology, the fatwa gives high value to science and scientific methods over traditional customs like fortune-tellers and healers as "fortunetellers turn out to be great sinners... without any reliable scientific knowledge whatsoever." Therefore, according to the fatwa, "it is enough for a person to consult a doctor at the first signs of the disease. However, there are quite a few believers who do not recognize the authority of doctors the efficacy of medical preparations. To preserve the health granted by God is the duty of every person. Indifference to their health [is] a great $\sin . " 189$ The fatwa praised the modern achievements of science, medicine, and healthcare of the Soviet era, and promoted struggle against superstitious and archaic practices in the region. It concluded that imam-khatibs in their "sermons and conversations with believers... should widely explain all the provisions of [relevant

\footnotetext{
187 Ibid.

188 Ibid.

189 Ibid.
} 
fatwas] and launch a serious struggle against heresy, inertia, prejudice and superstition." ${ }^{190}$

How much did SADUM influence the population? In 1952, 357 registered Muslim religious societies and mosques, the effective platform for popularizing SADUM's fatwas, operated in the Soviet Union, with seventy-four officially registered mosques in the Uzbek SSR, thirty-two in the Kyrgyz SSR, twenty-seven in the Tajik SSR, twenty in the Kazakh SSR, and four in the Turkmen SSR. ${ }^{191}$ By 1973, SADUM controlled 145 registered mosques (sixty-five in Uzbek SSR, seventeen in Tajik SSR, thirty-three in Kyrgyz SSR, four in Turkmen SSR, and twenty-six in Kazakh SSR). ${ }^{192}$ There was a slight decrease in numbers of registered mosques, suggesting that SADUM's influence among local population was decreasing over time.

However, the Muslim public may only have seen registered mosques as a place of worship, without accepting the fatwas circulated in those mosques. Local communities were especially suspicious (and could easily ignore) ideas such as "fasting is not required" and "headscarf is not required" issued by the SADUM mufti and delivered by official imams. Especially with the presence of unofficial ulama who regularly challenged official opinions, communities could be more resistant towards the radically different ideas of official imams.

\footnotetext{
190 Ibid.

191 Dmitriy Arapov, Islam i sovetskoe gosudarstvo (1944-1990). Sbornik dokumentov. Vypusk 3 (Moskva: Mardzhani, 2011), 99.

192 Dmitriy Arapov, Islam i sovetskoe gosudarstvo (1944-1990). Sbornik dokumentov. Vypusk 3 (Moskva: Mardzhani, 2011), 278.
} 


\section{Unofficial Ulama}

SADUM was not alone in the region in promoting reformist and modernist ideas.

The examples of movements like Ahl Al-Hadith and Ahl Al-Quran among informal ulama show that the local unofficial ulama was also familiar with reformist ideas. Besides Z. Babakhanov, there were other "Wahabis", especially in the Ferghana region led by Molla Hakimjan Qori, who also promoted similar reformist ideas as part of the Ahl AlHadith movement. Ahl Al-Hadith, a movement that emphasized the hadiths over local traditions, originated in Soviet Central Asia from the teachings of Shami Domulla and his young disciples who continued his (reformist) work into the 1930s. Molla Hakimjon Qori became influential in the 1970s and raised the next generation of Ahl Al-Hadith members. Salafi tradition and Ibn Taymiyya, one of the most prominent historical figures cited in the Salafist tradition, especially influenced Hakimjon Qori's thought and work.

Another group of reformists called "Ahl Al-Quran" rejected the Soviet way of life. Ahl Al-Quran emerged out of Ahl al-Hadith. Led by Sabircha Domulla, influential in the Ferghana and Tashkent regions, criticizing Ahl Al-Hadith for excessively emphasizing hadiths. In addition, Ahl Al-Quran renounced the official religious representatives who worked with the Soviet state and advocated more ascetic views. Sabircha Domulla worked as muezzin (an assistant of imam in mosque who calls for prayers) for $Z$. Babakhanov's mosque and the two were close until the latter started to officially work in SADUM ${ }^{193}$ Ahl Al-Quran members rejected the madhabs (schools of jurisprudence in Islam), and found most hadiths problematic, hence giving more emphasis on the Quran.

\footnotetext{
${ }^{193}$ Ashirbek Muminov, "Fundamentalist Challenges to Local Islamic Traditions in Soviet and Post-Soviet Central Asia," in Empire, Islam, and Politics in Central Eurasia, ed. Tomohiko Uyama (Slavic Research Center, Hokkaido University, 2007).
} 
However, most of its adherents did not know Arabic and therefore read an Uzbek translation of the Quran.

In the 1970s these movements inspired a new generation of reformists such as Rahmatullah Allama, inspired by Ahl Al-Hadith, and Abduvali Qori Mirzoyev, influenced by Ahl Al-Quran. They were based in Andijan and presented themselves as mujaddidiyya, reformers, to the public in unofficial religious spaces. Both studied under Molla Hakimjon Qori and rejected the local Hanafi traditions. Both also studied in Domulla Hindustani's hujras. ${ }^{194}$

Domulla Hindustani and his followers held a more traditional and conservative view of Islam based in the Hanafi tradition. Hindustani studied theology in Kokand and Afghanistan, and later moved to Kashmir. In 1933, he returned to Kokand and was exiled to Siberia during state campaigns against religion. After being released, he became imam of a Dushanbe mosque. Throughout the 1970s and 1980s he was one of the most influential figures of informal Islam. Hindustani and his followers supported local traditional practices and accused reformists of being "Wahhabists" introducing "bid'at" into Islam. In fact, Domulla Hindustani was the first in Central Asia to use the term "Wahhabi" against his opponents, and the term later became prevalent in the region as a general and negative byword for all reformists, indicating the level of Hindustani's influence..$^{195}$

\footnotetext{
194 Babajanov, "Khudzhra."

195 Stanislav M. Prozorov, ed., Islam na territorii byvshey Rossiyskoy imperii: entsiklopedicheskiy slovar' (Moskva: Vostochnaya literatura, 2006), 428.
} 
However, most of these reformists did not follow Muhammad ibn Al Wahhab's school of thought. Therefore, some historians, like Babajanov, instead use the term "local Wahhabism" to identify local reformist movements particular to the Central Asian context, but not necessarily affiliated with the original sources of Wahhabism. Most of these reformists actually preferred to identify themselves with earlier Islamic theological labels such as "tajdid" and "mujaddid", meaning reform(er), but not as Wahhabist or Salafist. It is important to differentiate local reformist ideas from Saudi Salafism, because such Central Asian reformist discourses actually developed in the Soviet context where an atheist regime attempted to control religious beliefs through official religious organizations.

Hindustani and his opponents like Rahmatullah Allama also debated such topics as the legitimacy of non-Muslim authority over Muslims. In one of his writings, Hindustani confronted criticisms of non-Muslim authority:

Now God has made the situation of people [in the Soviet Union] different: all go to the mosque without fear, [and attend] the communal prayer. Is this not the mercy of Allah? And you blame us that we say, "Glory to Allah!" for this reason. You did not live in those days [when religion was suppressed in the USSR, referred to anti-religious campaign], perhaps not even yet born. And yet, because of your shamelessness and unreasonableness, you said that you should [for all this] thank only the state. You don't think its God's mercy? Do you not believe the saying: "And goodness, and calamities from Allah Almighty?". I have experienced so much that I give thanks [to God] for these days. ${ }^{196}$

Opponents of Hindustani accused him of being loyal to the Soviet "atheist" state, believing that non-Muslim leaders were illegitimate. By contrast, Hindustani believed that the lack of restrictions against praying and practicing religion was sufficient to

${ }^{196}$ Babajanov, Muminov, and Kügelgen, Disputy musul'manskikh religioznykh avtoritetov, 119. 
accept any government, even if not Muslim, as legitimate. Although, there were restrictions on praying, Hindustani implied relative freedom of religion in 1970s comparing to previous decades in the USSR. However, in response to other reformists (at the other end of the spectrum) who praised the government over God in providing religious freedom in the USSR, Hindustani quoted the Quran to emphasize that all, good and bad, was due to God's will. (Hindustani represented a moderate position that abstained from enthusiastically denouncing or praising the Soviet state.) While the younger reformist generation was more ambitious to call for struggle, or jihad, against the Soviet state, the older conservative generation of ulama, like Hindustani, preferred quiet compromise with the state. Hindustani was more concerned with preserving traditions and transferring religious teachings to future generations, and intentionally avoided direct confrontation with the Soviet authorities.

Nasriddin Toychiyev, or Nasriddin Ahun, was another leading figure of conservative Hanafites in Kokand. Hindustani and Nasriddin Ahun typified Soviet Islam, who were willing to accommodate the Soviets and sought conciliation with the authorities even as they maintained connections with and an influential presence among "unofficial" religious circles. Both individuals trained many disciples who later became reformists (despite their teachers' traditionalist views). Especially towards the 1970s, the younger generation educated in hujras became increasingly reformist, possibly in part because of the rising influence of foreign exchanges. Official positions in SADUM were also mostly filled by reformists, indicating that the overall influence of the reformist line was rising in Central Asia among official and unofficial ulama. 
Reformist individuals like Babakhanov largely led SADUM. The Soviet state supported the reformist line by extension through SADUM, even as other reformists among "unofficial" ulama, like R. Allama, with similar religious interests as the Babakhanovs, increasingly opposed the Soviet state. At the same time, traditionalist ulama like Hindustani sought conciliation with the Soviet state, even as their reformist rivals attained positions and power in the official bureaucracy. The Babakhanovs never openly opposed the Soviet state and always tried to prove their loyalty to the authorities. However, Z. Babakhanov also protected the Ahl Al-Hadith and Ahl Al-Quran movements, critical of the state, and tried to hire members of these movements into official positions.

Competition over control of (unofficial) mosques between conservative ulama and reformists also shows how the network of official and unofficial ulama in Central Asia overlapped. While some disciples of Nasriddin Ahun gained control over the unregistered mosques in the Ferghana region, others among his students (who became reformist) competed for control of mosques against him. The same was true for the disciples of Hindustani, like Abdulatif Kari, who became a reformist.

Recognizing the Hanafi school as an important part of local tradition, some reformists like Muhammad Rajab initially did not openly oppose Hanafites, instead calling for reforms within the local Hanafi tradition. ${ }^{197}$ However, they also realized that unique, local practices of Islam obstructed their vision of a unified religion in Central Asia, without the divisions of different schools of thought, that could be integrated with

${ }^{197}$ Babajanov, Muminov, and Kügelgen, 139. 
the global ummah. Reformist attempts to return to the original sources by ignoring (or challenging) the local forms of Islamic practices had a political dimension, which was based on Islamist ideologies in Middle Eastern countries, like the Egyptian Muslim Brotherhood, which wanted a re-unified umma. Therefore, Z. Babakhanov's significant stress on the uniqueness of Central Asian Islam contrasted with the aims of other Central Asian reformists who wanted to align Islam in the region with political trends outside of the USSR. However, Z. Babkhanov as mentioned before, in practice followed global trends. Here, Z. Babakhanov played a centrist role between reformists and conservatives, albeit to some extent leaning towards reformists. The centrist position of SADUM strengthened towards the 1980 s as the influence of radical Islamists abroad and in Central Asia was growing.

\section{International Influence}

As discussed in the second chapter, the Soviets (at the same time) sent ulama from SADUM to meet with representatives of Islamic institutions from other countries in order to promote a positive, and internationalized image of the Muslims in the Soviet Union. As a result of meetings with Egyptian, Saudi Arabian and Turkish representatives of Islamic institutions, SADUM was informed about global developments and able to disseminate this knowledge through formal and informal networks in Soviet Central Asia.

There were four different sources of foreign influence on Soviet Muslims: Muslim students going abroad; foreign diplomatic exchanges; international students from the Middle East (who could bring books and journals); and radio stations across the border 
in Iran, Afghanistan and Turkey. ${ }^{198}$ The influence of international scholars is visible among unofficial ulama as well. For instance, Molla Hakimjon Qori's personal library included the books of other foreign Muslim scholars, such as Hassan Al-Banna (the Egyptian imam who founded Muslim Brotherhood) and Abul Al'a Maududi (Pakistani imam and founder of Jamaat-e Islami, one of the biggest religious organizations in South Asia), that were influential in disseminating political Islamist ideologies. ${ }^{199}$ In the 1970s the literature of reformist and modernist scholars like Sayyid Qutb (Egyptian scholar, and founding member of the Muslim Brotherhood) from Arabic countries started to appear in the libraries of local ulama in Central Asia. ${ }^{200}$ These examples signify the fact that local ulama in Central Asia were exposed to international reformist ideas during the Soviet era.

Soviet embassies in Muslim countries studied and reported on the situation of Islam abroad, particularly interested in how other governments tried to control different religious movements by supporting certain religious scholars and institutions while eliminating others. The reformist agenda in SADUM in 1960s and 1970s coincided with the emergence of various reformist movements in Central Asia and other countries in the Middle East. As Islam in Central Asia was under foreign influence, the official clergy understood the domestic situation in Central Asia as unique and different from other

\footnotetext{
198 Babajanov, Muminov, and Kügelgen, Disputy musul'manskikh religioznykh avtoritetov, 21.

199 Babajanov, Muminov, and Kügelgen, 21; Olcott, "Roots of Radical Islam in Central Asia", 8.

200 Bakhtiyar M. Babajanov, Ashirbek Muminov, and Anke von Kügelgen, Disputy musul'manskikh religioznykh avtoritetov v Tsentral'noy Azii v XX veke (Almaty: Dayk-Press, 2007), 21; Sebastien Peyrouse, "The Rise of Political Islam in Soviet Central Asia," Current Trends in Islamist Ideology; Washington 5 (2007): 40-54, 83; Martha Brill Olcott, "Roots of Radical Islam in Central Asia," Russia and Eurasia Program (Washington: Carnegie Endowment for International Peace, January 2007), https://carnegieendowment.org/2007/01/17/roots-of-radical-islam-in-centralasia-pub-18967.
} 
Muslim countries (not under avowedly secular rule) and was adaptive to local circumstances in how it received books and publications from foreign countries. Ziyauddin Babakhanov's response in 1978 to a letter from Al-Kharaqani, from the MWL, the Saudi counterpart of SADUM, which inquired about women's rights in Central Asia is a notable example. Z. Babakhanov pointed out local conditions in Central Asia, being both Islamic and modern at the same time, differed significantly from Saudi Arabia:

The question of women's emancipation had already appeared in the Arab East in the second half of the 19th century. Great philosophers and reformers of the East such as Muhammad Abduh, Rashid Rida, and Qasem Amin, as well as many others devoted a great portion of their intellectual labor to this very issue. In defense of their viewpoints, they found support from the Islamic sharia. And they enjoyed well-known success in this respect. In our country, women's emancipation commenced after the October revolution when women received equal rights with men in all respects. At the same time, it is important to note that in our country the constitution guarantees complete freedom of conscience and respect for all national traditions and religious rites of the peoples of the USSR. Therefore, the religious organizations of the Soviet Union, and our Spiritual Board, in particular, issue fatwas from time to time concerning questions emerging in Muslims' spiritual life in the conditions of modernity. One of these fatwas was issued by my late father, the Mufti Eshon Babakhanov, allowed women not to wear the paranji [headscarf]. ${ }^{201}$

Babakhanov, in this letter, distinguishes Soviet Central Asia from the Arab world.

In spite of the acknowledged commonalities with the Arab world in addressing similar challenges in the modern age such as the progress of women emancipation, Central Asia is positioned as Muslim and modern within the distinct context of progressing under the Soviet state. Thus, SADUM under the leadership of Z.Babakhanov tried to promote its own understanding of religion which was compatible with the Soviet way of life, in a way that justifiably explained its differences with other parts of the Islamic world.

201 Tasar, "Soviet and Muslim”, 438. 


\section{The Centrist Line after Z. Babakhanov}

During the relatively freer environment for religious activities in the 1980s, the competition between these different Islamic discourses and movements became more openly political, usually in the form of gaining control over mosques as the number of mosques increased. The mosque was not just a space for religious prayer but other social activities as well, as people gathered to celebrate different festivities. In the wake of this competition, several central mosques in the Ferghana, Namangan, Margilan and Andijan regions were controlled by reformists, led by Avduvali Qori, who turned these places into centers of struggle against the conservative tradition. In several places of the Ferghana valley and in Kokand, the conflict sometimes escalated to physical attacks on conservative imams. ${ }^{202}$

In 1982, after Ziyauddin Babakhanov's death, his son Shamsiddin Babakhanov was elected as the next mufti. However, he was not very enthusiastic in continuing the reformist agenda of his father. A fatwa compiled in October 1983 and signed by the mufti S. Babakhanov was presumably issued in response to a March 1983 decree of the Central Committee of the Uzbek Communist Party, which described growing local interest in the traditional literature and the revival of old rituals as an unacceptable return to "medieval remnants". ${ }^{203}$ The fatwa condemned three kinds of illegally reproduced books as incompatible with sharia, and forbade their distribution and possession. The first group were compositions written by local, so-called "unofficial" ulama. The second group were copies of old lithographs and manuscripts detailing the

\footnotetext{
202 Babajanov, Muminov, and Kügelgen, Disputy musul'manskikh religioznykh avtoritetov, 140.

203 Babajanov, "O fetvakh SADUM protiv 'neislamskikh obychaev'”, 6.
} 
practice of religious activities that SADUM had already proscribed, such as certain kinds of weddings and religious holidays like Mawlid. The third group of essays, recognized in this fatwa as "harmful and unlawful", dealt with similarly proscribed ceremonial rituals. ${ }^{204}$ This fatwa indicates the continuation of struggle against local traditions and customs in 1983.

Despite the relative openness of perestroika in the 1980s, the activities of S. Babakhanov encountered a very difficult period. The Soviet muftiates across the USSR, in the 1980s, especially SADUM experienced a state of crisis, absorbed in internal problems, primarily the growing expansion of radical Islamists. In the second half of January and the beginning of February in 1989, there were open protests against S. Babakhanov in Tashkent, ultimately prompting Babakhanov's superiors to relieve him of his post. ${ }^{205}$

Although the late 1980s goes beyond the scope of this paper, it is important to note that centrist position of official ulama became more clear during this period. Muhammad Sodik, the last mufti of SADUM from 1989 to 1993, tried to hold a centrist position between these traditionalists and reformists, and described himself and his centrist supporters as "mollas of the state". In 1990 he organized and held a kurultai gathering both sides, which published "fatwa for peace". The meeting and the fatwa did not end the schism, and the disputes still continued. One of M. Sodik's reforms was the election of imams by the community without state interference, which actually led to

\footnotetext{
204 Ibid.

205 Dmitriy Arapov, Islam i sovetskoe gosudarstvo (1944-1990). Sbornik dokumentov. Vypusk 3 (Moskva: Mardzhani, 2011), 458.
} 
more conflicts among ulama. Letters written by Fathiddin Toychiyev, the younger brother of Nasriddin Ahun, in 1990 reveals rising conflict between different factions around elections of imams for the mosques in Ferghana region. ${ }^{206}$ The lack of interference by state authorities or SADUM may have either been because officials supported the reformists who were gaining more power through elections, or because the growing weakness of state capacity lessened its control over religious life.

This shift in the style and position of the mufti, also coincided with (similar) changes in Middle Eastern countries. For example, the Saudi organization, Islamic Academy of Fiqh at an annual meeting in Mecca in October 1987 addressed the "longstanding issue of discrepancies in matters of fiqh [jurisprudence] between madhhabs," and in particular the reaction of younger generations against conventional approaches to fiqh among the madhabs. The meeting concluded with the following declaration: "As for the groups that call for the rejection of the madhabs, force the Muslims to follow the path of the new ijtihad... we declare the following: there is one extremely alarming factor in the advantages of the madhabs and their imams. It prescribes the rejection of unscrupulous methods that mislead believers, breeding disagreement between them. Now we especially need unity and harmony, which will help us to resist the dangerous machinations of the enemies of Islam. ${ }^{207}$ Significantly, the declaration demonstrated a shift among ulama in Mecca, officially following the state Wahabist line, who became more tolerant towards the traditional madhabs in the 1980s. Moreover, social and political, rather than theological, implications of international disputes between

\footnotetext{
${ }^{206}$ Babajanov, Muminov, and Kügelgen, Disputy musul'manskikh religioznykh avtoritetov, 136.

207 Babajanov, Muminov, and Kügelgen, 239.
} 
traditionalists and reformists motivated this official shift. The contemporary position of official ulama in SADUM shifted as well, possibly due to similar social and political concerns. Since religious space and ritual in Islam such as mosque and prayer have collective social and political dimensions in organizing communities and shaping public opinion, the official Soviet clergy realized that debates over dogma and practice could lead to deeper polarization in society.

\section{Conclusion}

Despite the repressive and intrusive Soviet regime, SADUM administrators and other, sometimes unofficial, religious actors in Central Asia continued to engage in religious debates that confronted and challenged official state narratives of secularism in Soviet society. The dispute among local ulama in Central Asia continued and evolved in parallel with the Muslim world in general. Similarities with Wahabists abroad, and influences from reformist movements in Pakistan and Egypt, shows that the Soviet ulama managed to stay in touch with the outer world.

Atheist repression and foreign influence through religious diplomacy and educational exchanges alternately shaped Islam in Central Asia during the Soviet era. In addition, the lack of experts opened a gap between generations as young ulama became reformist while the older generation of ulama remained conservative. Although SADUM increasingly tried to play a centrist role among these schisms, it was penetrated by the reformists (e.g., Ahl Al-Quran, Ahl Al-Hadith members formerly appointed by Babakhanov), who paradoxically incorporated radical anti-Soviet discourses into Soviet Islam. 
By exploring transnational exchanges with religious institutions from other Muslim countries, the chapter addressed the question of how SADUM positioned itself in relation to the modern world and contemporary Muslim debates. While engaging foreign ulama and religious institutions to articulate his own reformist vision of Islam in Central Asia, Z. Babakhanov also emphasized the unique conditions of Central Asia under Soviet transformation to justify its differences with other Muslim societies in reform. Z. Babakhanov's style revealed the shift among official ulama in Central Asia from 1950s to 1980 s. This change was not only a result of local factors, but also paralleled shifts among other reformist clergies in the Middle East (to be more accommodating towards tradition) in general. Discourses of reform in Soviet-era Central Asian Islam was under the influence of many actors, local and international, official and unofficial. 


\section{Conclusion}

This paper examined SADUM's diplomatic role as it became an asset in international affairs during the fifties and sixties, due to Khrushchev's ambitions to restore the Bolshevik revolution in the East. In 1961, a separate Department of International Affairs for Muslim Organizations was established within the CARC. The department opened new opportunities for SADUM in their relationship with the outside world. SADUM started to publish the journal Muslims of the Soviet East in English, French, Arabic and Uzbek to inform foreign audiences about the freedom of conscience in the USSR. In addition, a limited number of students from Central Asia were sent to the Middle East to study Islam.

SADUM and the madrasas stood as proof to foreign Muslims that local Muslim actors were included in the Soviet modernization project. Muslim clergy from Central Asia therefore were allowed and encouraged to travel outside the USSR to speak about the positive condition of Islam in Soviet Central Asia. Here, the positive condition of Islam in the USSR was not necessarily about religious dogmas. Muslim clergy and students were encouraged to talk about material progress such as economic, cultural and technological achievements in Central Asia, rather than religious discourse or contemporary Islamic ideas. Involving Muslim clergy in diplomatic relations also helped to promote the USSR's image in its self-declared international struggle for peace and anti-colonialism. Official Muslim clergy used Islamic messages in order to call for international peace and friendship, criticize Western countries for being colonialist and oppressing Muslims. 
SADUM's involvement in international affairs shaped domestic religious affairs. While the USSR remained closed to the outside world for most of its citizens, SADUM was one of the few organizations that had an extensive relationship with foreign Islamic institutions and figures. SADUM decided which graduates of Soviet official madrasas would go to the Middle East for further studies. Moreover, SADUM decided who could go on Hajj. Thus, engagement with the international arena and power over the mobility of Soviet Muslims gave SADUM an important status among Central Asian Muslims.

SADUM assisted the CARC in controlling religious societies in Central Asia. The primary approach was to register mosques and imams. However, the proportion of registered mosques in the 1970 s and 1980s was lower than in the 1950s, indicating that official organizations had been losing control over the region. In addition, inter-ethnic tension among Central Asian republics may have played a role in this decline as the governments of Turkmenistan and Tajikistan refused to be part of an All Union Central Spiritual Administration. This ethnic dimension in Soviet religious affairs has not yet been studied and opens new possibilities for future studies.

Soviet official madrasas attempted to train unitary cadres for use in the Soviet bureaucracy. For this purpose, the curriculum of Soviet madrasas was designed to teach secular subjects in addition to religious subjects. The combination of secular and religious subjects, however, also resembled similar trends in foreign Muslim institutions such as Al Azhar, which also incorporated secular subjects. Another aspect is the Jadidi legacy, a modernist progressive movement in the early- $20^{\text {th }}$ century, that aimed to modernize education. Jadidi projects established "new method" schools that combined secular and religious subjects. Thus, Soviet official madrasas were influenced by 
various actors and trends in the wider Muslim world. Besides the Soviet state, it was also impacted by Jadidism, Salafism and local informal networks of ulama.

The debate between the local official and unofficial ulama around different religious topics demonstrated local ulamas' agency in shaping Islamic discourse during the Soviet era. Official and unofficial ulama had to navigate between different visions of Islam, like traditional interpretations led by individuals such as Domulla Hindustani, and reformist interpretations led by figures such as Z. Babakhanov or Abduvali Qori. This religious debate and conflict over the vision of Islam manifested even under the Soviet authoritarian regime, as there were different kinds of Islamic movements with different types of interpretations of Islam. The SADUM leadership, concerned about the social and political implications of local and international influences with different radical tendencies, tried to hold a centrist position between these views. However, the official positions in SADUM mostly fell under the influence of reformers, which also coincided with the Soviet modernization project and the view of international Muslim scholars. The shift in SADUM's position from reformist to centrist paralleled the position of Wahhabi ulama in Saudi Arabia. This relationship between local and international reformist tendencies in the 1970 s and 80 s needs further study. 


\section{Bibliography}

Akhmadullin, Vyacheslav A. 'Deyatel'nost' Partiyno-Gosudarstvennogo Apparata SSSR i Dukhovnogo Upravleniya Musul'man Sredney Azii i Kazakhstana Po Izdaniyu i Rasprostraneniyu Musul'manskikh Zhurnalov v 1945-1991 Gg." Vestnik Dagestanskogo Gosudarstvennogo Universiteta 4 (2014): 97-105.

. 'Deyatel'nost' sovetskogo gosudarstva po privlecheniyu musul'man k bor'be za mir v 1940-kh-1950-kh gg.” Vlast', no. 9 (2013).

. "Islamskiy faktor vo vneshney politike Soyuza Sovetskikh Sotsialisticheskikh

Respublik." Forumy rossiyskikh musul'man. Yezhegodnyy nauchno-analiticheskiy byulleten’ № 3 (2007).

. "Osobennosti sovetskoy sistemy dvukhurovnevoy podgotovki islamskikh kadrov: opyt i uroki." Islam v sovremennom mire 11, no. 2 (2015): 153-64.

. "Otdel mezhdunarodnykh svyazey musul'manskikh organizatsiy SSSR v strukture Soveta po delam religioznykh kul'tov: opyt sozdaniya i normativnye osnovy deyatel'nosti." Islamovedenie 7, no. 2 (2016).

. 'Patrioticheskaya Deyatel'nost' Musul'man Rossii v Gody Velikoy Otechestvennoy Voyny (Po Materialam Soveta Po Delam Religioznykh Kul'tov Pri SNK SSSR).” Vestnik Rossiyskogo Universiteta Druzhby Narodov. Seriya: Istoriya Rossii, no. 1 (2016).

Arapov, Dmitriy. "Musul'manskiy triptikh: Islam i Sovetskaya vlast'. 1917-1949-1982." Pax Islamica, no. 1 (2) (2009): 248-66.

Arapov, Dmitriy, and Grigoriy Kosach. Islam i sovetskoe gosudarstvo (Po materialam Vostochnogo otdela OGPU. 1926 g.). Vypusk 1. Moskva: Mardzhani, 2010.

Asad, Talal. Formations of the Secular: Christianity, Islam, Modernity. Stanford University Press, 2003.

Babajanov, Bakhtiyar M. "Khudzhra." In Islam na territorii byvshey Rossiyskoy imperii: entsiklopedicheskiy slovar'. Tom I, edited by Stanislav M. Prozorov. Moskva: Vostochnaya literatura, 2006.

. "O fetvakh SADUM protiv 'neislamskikh obychaev."” In Islam na postsovetskom prostranstve: vzglyad iznutri, edited by Aleksey V. Malashenko and Martha Brill Olcott. Moskva: Moskovskiy Tsentr Karnegi, 2001.

. "Ulama'-Orientalists: Madrasa Graduates at the Soviet Institute of Oriental Studies." In Reassessing Orientalism, 94-129. Routledge, 2015.

Babajanov, Bakhtiyar M., Ashirbek Muminov, and Anke von Kügelgen. Disputy musul'manskikh religioznykh avtoritetov v Tsentral'noy Azii v XX veke. Almaty: DaykPress, 2007.

Bennigsen, Alexandre, and Chantal Lemercier-Quelquejay. "'Official' Islam in the Soviet Union." Religion in Communist Lands 7, no. 3 (1979): 148-59.

Berger, Peter. "From Sect to Church: A Sociological Interpretation of the Baha'i Movement." Ph. D., New School for Social Research, 1954.

Bruinessen, Martin van. "The Governance of Islam in Two Secular Polities: Turkey's Diyanet and Indonesia's Ministry of Religious Affairs." European Journal of Turkish Studies. Social Sciences on Contemporary Turkey, no. 27 (December 31, 2018). http://journals.openedition.org/ejts/5964.

Cornell, Svante E., and Jacob Zenn. "Religion and the Secular State in Uzbekistan." Uzbekistan's New Face, 2018, 193. 
DeWeese, Devin. "Islam and the Legacy of Sovietology: A Review Essay on Yaacov Ro'i's Islam in the Soviet Union.” Journal of Islamic Studies 13, no. 3 (2002): 298-330.

Erşahin, Seyfettin. "The Official Interpretation of Islam under the Soviet Regime: A Base for Understanding the Contemporary Central Asian Islam." Hamdard Islamicus: Quarterly Journal of Studies and Research in Islam 28, no. 4 (2005): 7-25.

Esposito, John L. Political Islam: Revolution, Radicalism, or Reform? Lynne Rienner Publishers Boulder, CO, 1997.

Gözaydın, İștar B. "Diyanet and Politics.” The Muslim World 98, no. 2-3 (2008): 216-27.

- "Religion, Politics, and the Politics of Religion in Turkey." In Religion, Politics, and Turkey's EU Accession, 159-76. Palgrave Studies in Governance, Security, and Development. Palgrave Macmillan, New York, 2008. https://doi.org/10.1057/9780230615403_8.

Guseva, Yuliya N. “Mrachnoe Ekho Dela TsDUM: Tsep’ Korana i Repressii Protiv Musul'manskoy Elity v SSSR (1940 God)." Novyy Istoricheskiy Vestnik, no. 2 (52) (2017).

Hussin, Iza R. "Sunni Schools of Jurisprudence." In The Oxford Encyclopedia of Islam and Politics, edited by Emad El-Din Shahin, P. J. Bearman, S. H. Hashmi, J. A. Kechichian, and K. Keshk. Oxford University Press, 2014.

- The Politics of Islamic Law: Local Elites, Colonial Authority, and the Making of the Muslim State. Chicago: University of Chicago Press, 2016.

Idrisov, Umar. Bukharskie vospominaniya. 20 let sluzheniya imamom. Nizhniy Novgorod: Izdatel'skiy Dom "Medina," 2007, http://www.idmedina.ru/books/encyclopedia/?765, accessed 8/2/2019.

Kemper, Michael. Studying Islam in the Soviet Union. Vol. 321. Amsterdam University Press, 2009.

Khalid, Adeeb. Islam after Communism: Religion and Politics in Central Asia. Berkeley: University of California Press, 2007.

. Making Uzbekistan: Nation, Empire, and Revolution in the Early USSR. Cornell University Press, 2015.

. "Nationalizing the Revolution in Central Asia: The Transformation of Jadidism, 19171920." A State of Nations: Empire and Nation-Making in the Age of Lenin and Stalin, 2001, 145-62.

- The Politics of Muslim Cultural Reform: Jadidism in Central Asia. Vol. 27. Comparative Studies on Muslim Societies. Berkeley: University of California Press, 1998.

Khalilova, Zilola. "Slushateli Medrese Sovetskogo Uzbekistana (1945-1991 Gg.): Sotsial'naya Zhizn' i Povsednevnye Praktiki." Rossiya i Musul'manskiy Mir, no. 10 (304) (2017): 4964.

Khalilova, Zilola, and Bakhtiyar M. Babajanov. "Soviet Ideology in the Madrasa: Political Contexts and Educational Practice." Islamology 7, no. 2 (2017): 29-52.

Kirasirova, Masha. "Orientologies Compared: US and Soviet Imaginaries of the Modern Middle East.” In Reassessing Orientalism, 16-46. Routledge, 2015.

—. "The Eastern International: The 'Domestic East' and the 'Foreign East' in Soviet-Arab Relations, 1917-68.” Ph.D., New York University, 2014.

Kotkin, Stephen. Armageddon Averted: The Soviet Collapse, 1970-2000. Oxford University Press, 2008. 
Mohamed, Sirelkhatim. "Authority in Islam: The Institutionalization of Islam and the Elusive Transfer of Authority from Society to State." Journal of Georgetown University-Qatar Middle Eastern Studies Student Association 2015, no. 1 (March 18, 2015 ): 2. https://doi.org/10.5339/messa.2015.2.

Muminov, Ashirbek. "Fundamentalist Challenges to Local Islamic Traditions in Soviet and PostSoviet Central Asia." In Empire, Islam, and Politics in Central Eurasia, edited by Tomohiko Uyama. Slavic Research Center, Hokkaido University, 2007.

Muminov, Ashirbek, Uygun Gafurov, and Rinat Shigabdinov. "Islamic Education in Soviet and Post-Soviet Uzbekistan." In Islamic Education in the Soviet Union and Its Successor States, 233-89. Routledge, 2009.

Olcott, Martha Brill. "Roots of Radical Islam in Central Asia." Russia and Eurasia Program. Washington: Carnegie Endowment for International Peace, January 2007. https://carnegieendowment.org/2007/01/17/roots-of-radical-islam-in-central-asia-pub18967.

Olcott, Martha Brill, and Diora Ziyaeva. "Islam in Uzbekistan: Religious Education and State Ideology." Russia and Eurasia Program. Washington: Carnegie Endowment for International Peace, September 2008. https://carnegieendowment.org/2008/09/10/islamin-uzbekistan-religious-education-and-state-ideology-pub-21980.

Peyrouse, Sebastien. "The Rise of Political Islam in Soviet Central Asia." Current Trends in Islamist Ideology; Washington 5 (2007): 40-54,83.

Prozorov, Stanislav M., ed. Islam na territorii byvshey Rossiyskoy imperii: entsiklopedicheskiy slovar'. Moskva: Vostochnaya literatura, 2006.

Ro'i, Yaacov. Islam in the Soviet Union: From the Second World War to Gorbachev. Columbia University Press, 2000.

—. The USSR and the Muslim World: Issues in Domestic and Foreign Policy. Routledge, 2015.

Silant'ev, Roman A. Musul'manskaya diplomatiya v Rossii: istoriya i sovremennost': uchebnoe posobie. Moskva: IPK MGLU "Rema," 2010.

Tasar, Eren Murat. "Soviet and Muslim: The Institutionalization of Islam in Central Asia, 19431991.” Ph.D., Harvard University, 2010.

. "The Official Madrasas of Soviet Uzbekistan." Journal of the Economic and Social History of the Orient 59, no. 1-2 (2016): 265-302.

Usmankhodzhaev, Amirsaidkhan. Zhizn' muftiev Babakhanovykh: sluzhenie vozrozhdeniyu Islama v Sovetskom Soyuze. Nizhniy Novgorod: Izdatel'skiy Dom "Medina," 2008, http://www.idmedina.ru/books/history_culture/?1201, accessed 8/2/2019.

Yavuz, M. Hakan. Secularism and Muslim Democracy in Turkey. Cambridge University Press, 2009.

\section{Primary Sources}

Arapov, Dmitriy. Islam i sovetskoe gosudarstvo (1944-1990). Sbornik dokumentov. Vypusk 3. Moskva: Mardzhani, 2011.

Muslim Religious Board for Central Asia and Kazakhstan. "Muslims of the Soviet East." Muslims of the Soviet East 1 (1968). 